\title{
Evaluation of Quality-Assurance/Quality-
}

Control Data Collected by the U.S.

Geological Survey from Wells and Springs between the Southern Boundary of the Idaho National Engineering and Environmental Laboratory and the AECEIVED NOV 012000 Hagerman Area, Idaho, 1989 through 1995

By LINDA M. WILLIAMS and ROY C. BARTHOLOMAY, U.S. GEOLOGICAL SURVEY, and LINFORD J. CAMPBELL, IDAHO DEPARTMENT OF WATER RESOURCES

U.S. GEOLOGICAL SURVEY

Water-Resources Investigations Report 98-4206

Prepared in cooperation with the U.S. DEPARTMENT OF ENERGY 


\section{DEPARTMENT OF THE INTERIOR \\ BRUCE BABBITT, Secretary}

\section{U.S. GEOLOGICAL SURVEY \\ Thomas J. Casadevall, Acting Director}

For additional information write to:

U.S. Geological Survey

INEEL, MS 1160

P.O. Box 2230

Idaho Falls, ID 83403-2230
Copies of this report can be purchased from:

U.S. Geological Survey

Information Services

Box 25286, Federal Center

Denver, CO 80225 


\section{DISCLAIMER}

This report was prepared as an account of work sponsored by an agency of the United States Government. Neither the United States Government nor any agency thereof, nor any of their employees, make any warranty, express or implied, or assumes any legal liability or responsibility for the accuracy, completeness, or usefulness of any information, apparatus, product, or process disclosed, or represents that its use would not infringe privately owned rights. Reference herein to any specific commercial product, process, or service by trade name, trademark, manufacturer, or otherwise does not necessarily constitute or imply its endorsement, recommendation, or favoring by the United States Government or any agency thereof. The views and opinions of authors expressed herein do not necessarily state or reflect those of the United States Government or any agency thereof. 


\section{DISCLAIMER}

Portions of this document may be illegible in electronic image products. Images are produced from the best available original document. 


\section{CONTENTS}

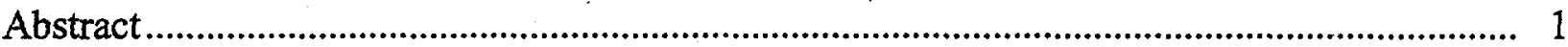

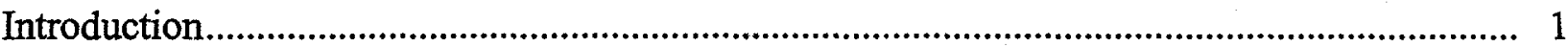

Purpose and scope ....................................................................................................... 3

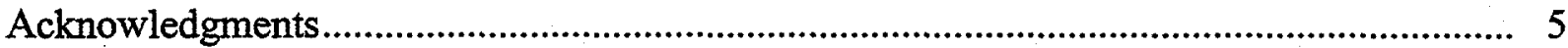

Quality-assurance/quality-control practices.............................................................................. 5

Sample collection and analytical methods .......................................................................... 5

Quality-assurance/quality-control samples, replicate pairs of samples .................................... 7

Statistical comparisons of replicate pairs of samples ................................................................. 8

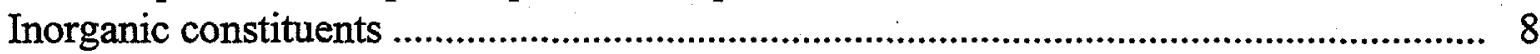

Gross radioactivity and radionuclides ................................................................................ 10

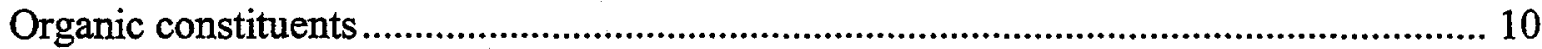

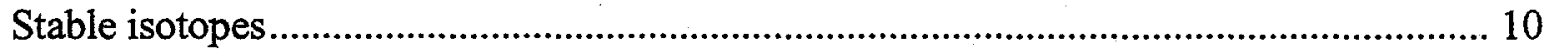

Summary of statistical comparisons of replicate pairs of samples ..................................... 11

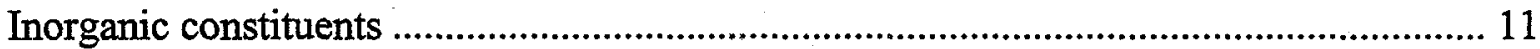

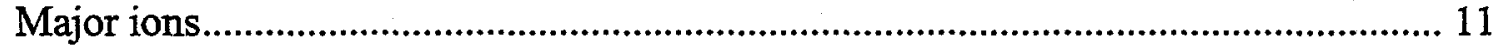

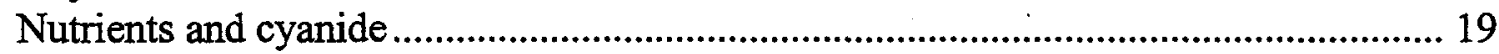

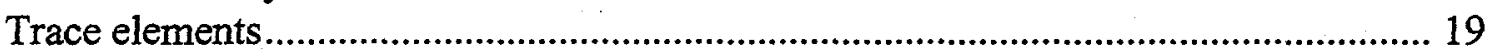

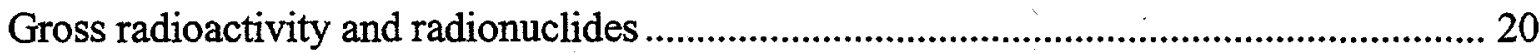

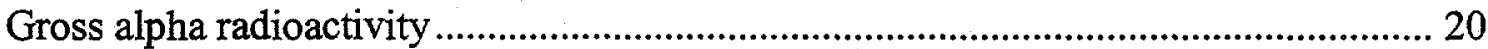

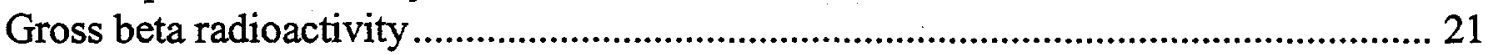

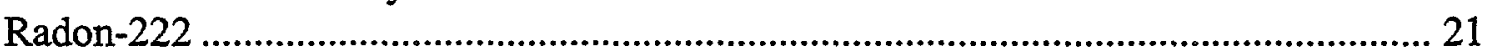

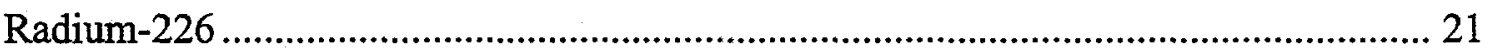

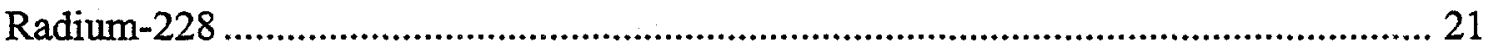

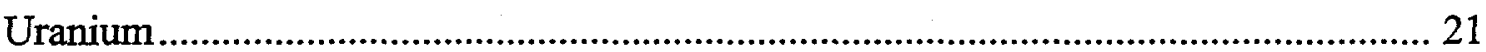

Strontium-90

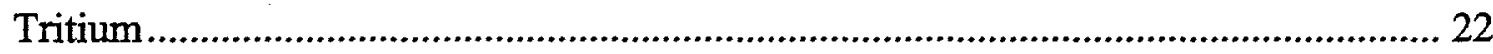

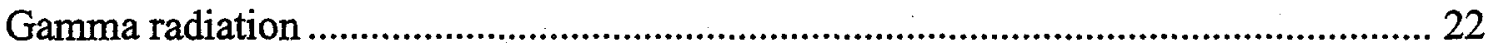

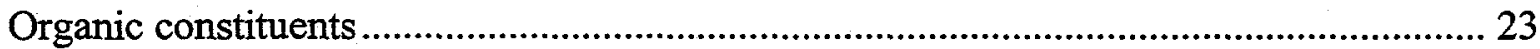

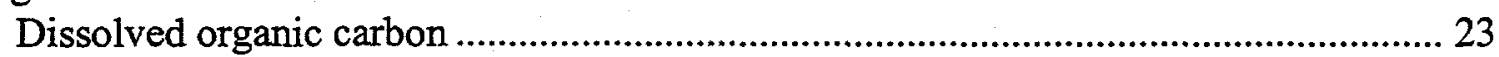

Anionic surfactants as methylene blue active substances ............................................ 23

Volatile organic compounds ....................................................................................... 23

Pesticides and gross polychlorinated compounds ..................................................... 24

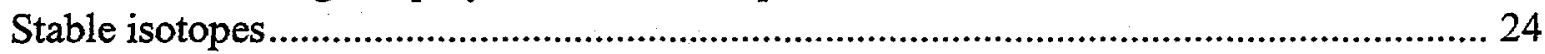

Quality-assurance/quality-control samples, blanks .................................................................. 24

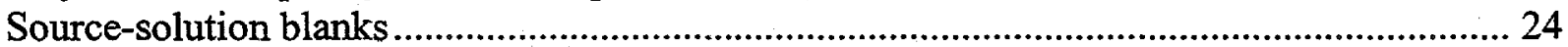

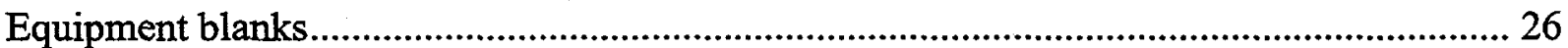

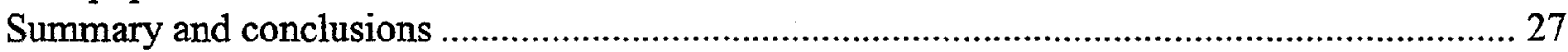

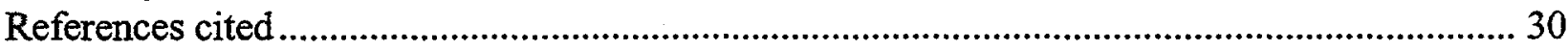

Supplemental information .................................................................................................... 33 


\section{FIGURES}

Figures 1-2. Maps showing:

1. Location of the study area, between the Idaho National Engineering and Environmental Laboratory and Hagerman, Idaho

2. Location of selected water-quality sampling sites in the study area where qualityassurance replicate samples were collected, 1989 through 1995

Figures 3-9. Graphs showing:

3. Results of statistical comparisons of replicate pairs of samples analyzed for major ions

4. Results of statistical comparisons of replicate pairs of samples analyzed for nutrients and cyanide.

5. Results of statistical comparisons of replicate pairs of samples analyzed for trace elements.

6. Results of statistical comparisons of replicate pairs of samples analyzed for gross radioactivity and radionuclides, National Water Quality Laboratory .

7. Results of statistical comparisons of replicate pairs of samples analyzed for gross radioactivity and radionuclides, Idaho State University

8. Results of statistical comparisons of replicate pairs of samples analyzed for organic constituents

9. Results of statistical comparisons of replicate pairs of samples analyzed for stable isotopes

\section{TABLES}

1. Laboratories and respective analyses for the water-quality samples from selected wells and springs, eastern Snake River Plain, 1989 through 1995

2. Identification, source, and description of source-solution and equipment blanks

3. Results of replicate pairs of samples from selected wells and springs, eastern Snake River Plain, analyzed for major ions.

4. Results of replicate pairs of samples from selected wells and springs, eastern Snake River Plain, analyzed for dissolved nutrients and cyanide

5. Results of replicate pairs of samples from selected wells and springs, eastern Snake River Plain, analyzed for trace elements

6. Results of replicate pairs of samples from selected wells and springs, eastern Snake River Plain, analyzed for gross radioactivity and radionuclides

7. Results of replicate pairs of samples from selected wells and springs, eastern Snake River Plain, analyzed for gamma radiation

8. Results of replicate pairs of samples from selected wells and springs, eastern Snake River Plain, analyzed for organic carbon and anionic surfactants as methylene blue active substances. 
9. Results of replicate pairs of samples from selected wells and springs, eastern Snake River Plain, analyzed for volatile organic compounds

10. Results of replicate pairs of samples from selected wells and springs, eastern Snake River Plain, analyzed for pesticides

11. Results of replicate pairs of samples from selected wells and springs, eastern Snake River Plain, analyzed for gross polychlorinated compounds

12. Results of replicate pairs of samples from selected wells and springs, eastern Snake River Plain, analyzed for stable isotopes.

13. Results of source-solution blanks analyzed for major ions 68

14. Results of source-solution blanks and an equipment blank analyzed for dissolved nutrients, cyanide, and organic carbon; and anionic surfactants as methylene blue active substances

15. Results of source-solution blanks analyzed for trace elements 70

16. Results of equipment blanks analyzed for trace elements .............................................. 71

17. Results of source-solution blanks analyzed for gross radioactivity and radionuclides ... 72

18. Results of source-solution blanks analyzed for gamma radiation .................................. 73

19. Results of source-solution and equipment blanks analyzed for volatile organic compounds 74

20. Results of an equipment blank, QA-MV, analyzed for volatile organic compounds ...... 75

21. Upper-tail areas for a normal curve 76

22. Volatile organic compounds, Chemical Abstracts Service (CAS) Registry numbers, minimum reporting levels, and years analyzed.

23. Pesticides and gross polychlorinated compounds, Chemical Abstracts Service (CAS) Registry numbers, minimum reporting levels, and years analyzed.

24. Site identifiers, site use, and years sampled. 82

\section{CONVERSION FACTORS AND ABBREVIATED UNITS}

\begin{tabular}{rll}
\hline Multiply & By & To obtain \\
\hline gram $(\mathrm{gr})$ & .0353 & ounce (oz) \\
kilometer $(\mathrm{km})$ & .6214 & mile $(\mathrm{mi})$ \\
$\operatorname{liter}(\mathrm{L})$ & .2207 & gallon (gal) \\
picocuries per liter $(\mathrm{pCi} / \mathrm{L})$ & 0.037 & bequerel per liter \\
square mile $\left(\mathrm{mi}^{2}\right)$ & 2.590 & square kilometer \\
\hline
\end{tabular}

For temperature, degrees Celsius $\left({ }^{\circ} \mathrm{C}\right)$ may be converted to degrees Fahrenheit $\left({ }^{\circ} \mathrm{F}\right)$ by using the formula $\mathrm{F}^{\circ}=\left(1.8\left({ }^{\circ} \mathrm{C}\right)+32\right.$. Abbreviated units used in report: $\mathrm{mL}$ (milliliter); $\mathrm{L}$ (liter); $\mu \mathrm{g} / \mathrm{L}$ (microgram per liter); $\mathrm{mg} / \mathrm{L}$ (milligram per liter); $\mathrm{pCi} / \mathrm{L}$ (picocurie per liter). 


\title{
Evaluation of Quality-Assurance/Quality-Control Data Collected by the U.S. Geological Survey from Wells and Springs between the Southern Boundary of the Idaho National Engineering and Environmental Laboratory and the Hagerman Area, Idaho, 1989 through 1995
}

\author{
By Linda M. Williams and Roy C. Bartholomay, U.S. GEOLOGICAL SURVEY, and Linford J. \\ Campbell, IDAHO DEPARTMENT OF WATER RESOURCES
}

\section{Abstract}

The U.S. Geological Survey (USGS) and the Idaho Department of Water Resources, in cooperation with the U.S. Department of Energy, collected and analyzed water samples to monitor the water quality of the Snake River Plain aquifer from the southern boundary of the Idaho National Engineering and Environmental Laboratory to the Hagerman area, Idaho. Concurrently, replicate samples and blank samples were collected and analyzed as part of the quality-assurance/quality-control program. Samples were analyzed for inorganic constituents, gross radioactivity and radionuclides, organic constituents, and stable isotopes.

To evaluate the precision of field and laboratory methods, analytical results of the waterquality and replicate samples were compared statistically for equivalence on the basis of the precision associated with each result. Statistical comparisons of the data indicated that 95 percent of the results of the replicate pairs were equivalent. Blank-sample analytical results indicated that the inorganic blank water and volatile organic compound blank water from the USGS National Water Quality Laboratory and the distilled water from the Idaho Department of Water Resources were suitable for blanks; blank water from other sources was not. Equipment-blank analytical results were evaluated to determine if a bias had been introduced and possible sources of bias. Most equipment blanks were analyzed for trace elements and volatile organic compounds; chloroform was found in one equipment blank. Two of the equipment blanks were prepared after collection and analyses of the water-quality samples to determine whether contamination had been introduced during the sampling process. Results of one blank indicated that a hose used to divert water away from pumps and electrical equipment had contaminated the samples with some volatile organic compounds. Results of the other equipment blank, from the apparatus used to filter dissolved organic carbon samples, indicated that the filtering apparatus did not affect water-quality samples.

\section{INTRODUCTION}

The Idaho National Engineering and Environmental Laboratory (INEEL) includes approximately $890 \mathrm{mi}^{2}$ of the eastern Snake River Plain in southeastern Idaho (figure 1). It was established in 1949 as the National Reactor Testing Station to reprocess used reactor fuel elements and to build, test, and operate prototype nuclear reactors. Later, the name was changed to the Idaho National Engineering Laboratory. Today, it is called the INEEL 


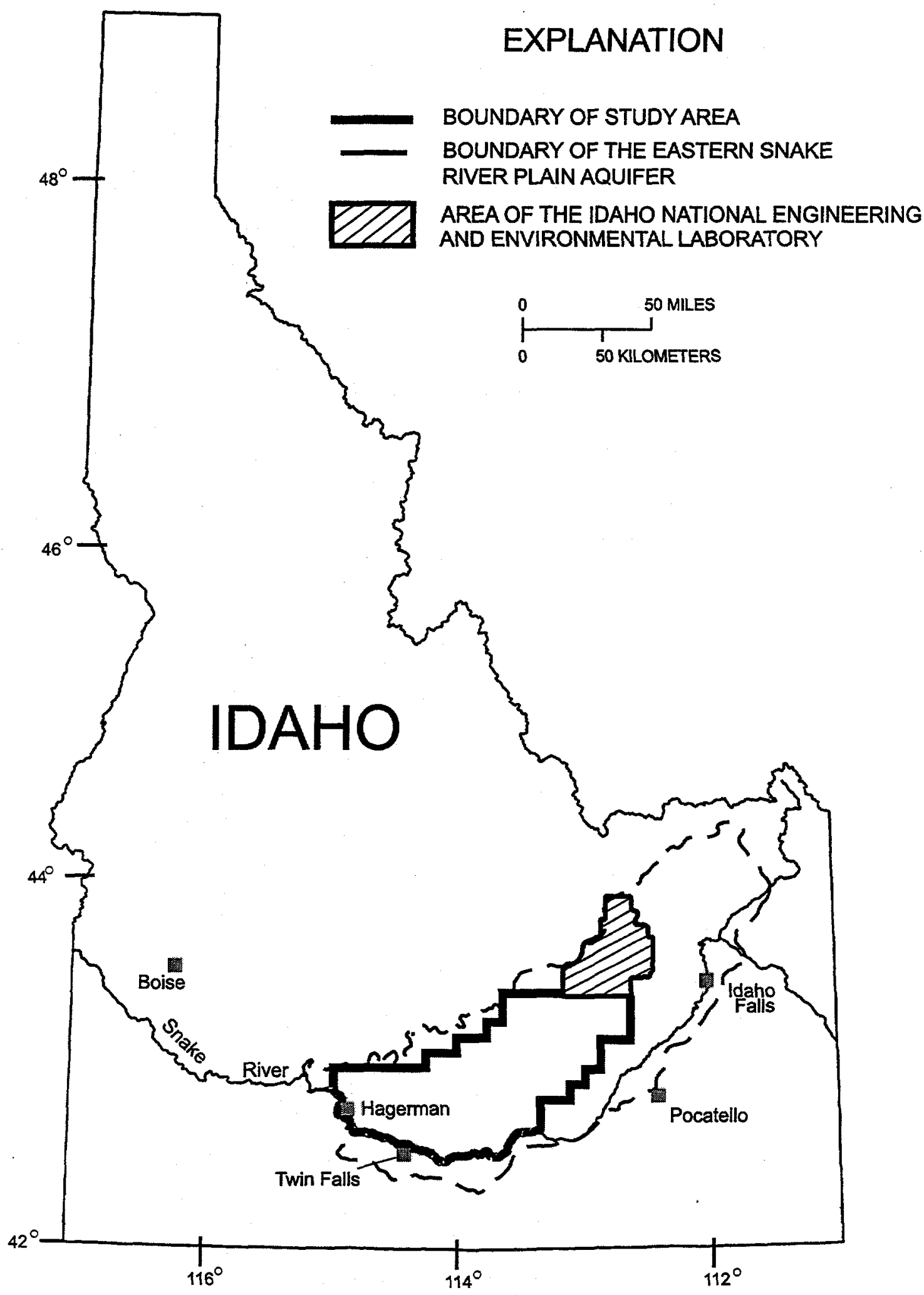

Figure 1. Location of the study area, between the Idaho National Engineering and Environmental Laboratory and Hagerman, Idaho. 
and is a center for nuclear-waste technology, environmental research and remediation, and development of advanced energy concepts. Activities at the INEEL have produced aqueous radioactive and chemical wastes that have been discharged into ponds and wells. Before 1984, most of those wastes were injected directly into the Snake River Plain aquifer through deep wells. Since 1984, most of the aqueous wastes have been discharged to unlined infiltration ponds and many of the waste constituents have entered the aquifer after percolation through the unsaturated zone.

The public is concerned about waste-disposal practices at the INEEL and the effects these practices may have on the water quality of the Snake River Plain aquifer. In response to this concern, the U.S. Department of Energy (DOE) requested that the U.S. Geological Survey (USGS) conduct two studies to gain a greater understanding of the water quality in the aquifer. The first study described a onetime sampling effort in the eastern part of the A \& B Irrigation District in Minidoka County, Idaho (Mann and Knobel, 1990). The second study, which has consisted of three rounds of sampling for a variety of inorganic constituents, gross radioactivity and radionuclides, organic constituents, bacteria, and stable isotopes thus far, is an ongoing effort in the area between the southern boundary of the INEEL and Hagerman, Idaho. It is being conducted with the Idaho Department of Water Resources (IDWR) in cooperation with the DOE.

The initial round of sampling for the second study involved collecting and analyzing water-quality samples from 55 sites during August and September, 1989, which included 26 irrigation wells, 13 domestic wells, 5 springs, 4 stock wells, 3 dairy wells, 2 observation wells, 1 commercial well, and 1 publicsupply well (Wegner and Campbell, 1991). The second round of sampling involved collecting and analyzing water samples from 19 of the initial 55 sites in 1990 (Bartholomay and others, 1992), another 18 sites in 1991 (Bartholomay and others, 1993), and the remaining 18 sites in 1992 (Bartholomay and others, 1994a). The third round involved resampling the initial 55 sites over the next threeyear period (Bartholomay and others, 1994b; and Bartholomay and others, 1995, 1996). During these three rounds of sampling, replicate samples and source-solution and equipment blank samples also were collected as part of the quality-assurance/quality-control (QAQC) program. Locations of the water-quality sampling sites in the study area where QA replicate samples were collected from 1989 through 1995 are shown in figure 2.

\section{Purpose and Scope}

The purpose of this report is to evaluate the QA/QC data collected during 1989-95 during the three rounds of sampling in the area between the southern boundary of the INEEL and Hagerman, Idaho to help assess precision of and bias introduced by both field and laboratory methods. Analytical results of replicate pairs of samples were compared statistically for equivalence. The source-solution and equipment blank analytical data also were evaluated.

The laboratories involved in the project were the USGS National Water Quality Laboratory (NWQL), Arvada, Colo.; the Idaho Department of Health and Welfare Laboratory (IDHWL), Boise, Idaho; and the Idaho State University (ISU) Environmental Monitoring Laboratory, Pocatello, Idaho. The inorganicconstituent data included analyses for major ions, nutrients and cyanide, and trace elements. The gross radioactivity and radionuclide data included analyses for gross alpha radioactivity, gross beta radioactivity, radon222 , radium- 226 , radium- 228 , uranium, strontium-90, tritium, and gamma radiation. Determinations of organic constituents included dissolved organic carbon (DOC), anionic sur- 


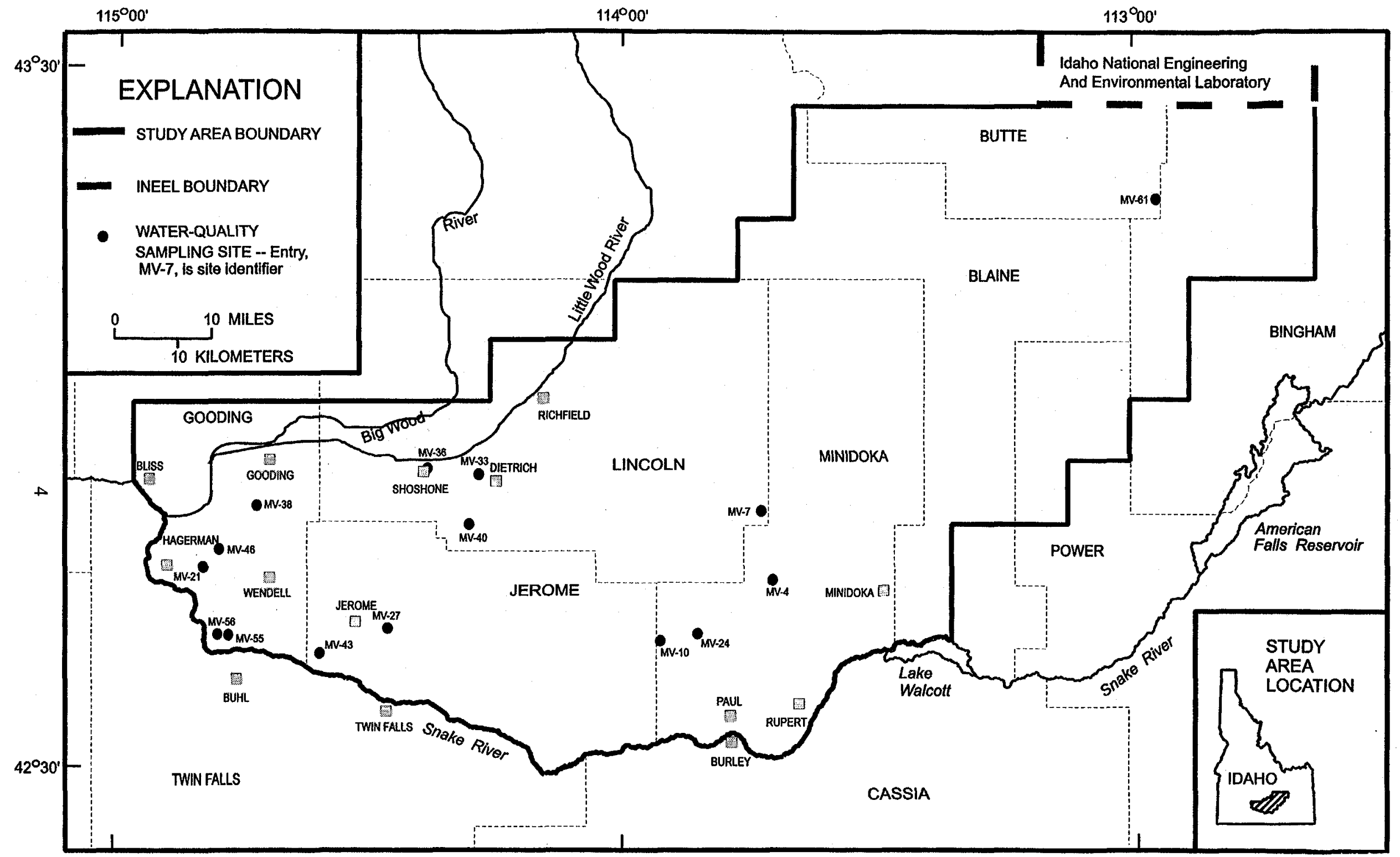

Figure 2. Location of water-quality sampling sites in the study area where quality-assurance replicate samples were collected, 1989 through 1995. 
factants as methylene blue active substances (MBAS), volatile organic compounds (VOC's), pesticides, and gross polychlorinated biphenyls (PCB's) and naphthalenes (PCN's). The following stable-isotope ratios, relative to a standard, were determined: hydrogen-2/ hydrogen-1, oxygen-18/oxygen-16, carbon13/carbon-12, sulfur-34/sulfur-32, and nitrogen-15/nitrogen-14. The laboratories and respective analyses are listed in table 1.

\section{Acknowledgments}

The authors are grateful to the well owners for granting permission to collect the water samples. We also thank the employees at the NWQL, IDHWL, and ISU who analyzed the water samples described in this report. The authors are especially grateful for the technical reviews by Ken Neeley of the IDWR and Ann Mullin of the NWQL.

\section{QUALITY-ASSURANCE/QUALITY- CONTROL PRACTICES}

The three rounds of sampling, including site selection, sample containers and preservatives, sample collection, analytical methods and minimum reporting levels (MRL's), interpretation of radiochemical results, and quality assurance are described in yearly reports (Wegner and Campbell, 1991; Bartholomay and others, 1992, 1993, 1994a, 1994b; and Bartholomay and others, 1995, 1996).

The USGS is committed to collecting water samples that are as representative of the sampling site as possible and to reporting reliable and reproducible data. Water samples were collected in accordance with a qualityassurance plan and field methods for qualityof-water activities conducted by personnel at the INEEL Project Office. The plan was finalized in June 1989, and revised in March, 1992, and in 1996 (Mann, 1996). This plan defines the required procedures and tasks to ensure the reliability of water-quality data at the INEEL. A brief description of the procedures and tasks is included in this report.

A comprehensive description of the quality-assurance practices at the NWQL is presented by Friedman and Erdmann (1982) and Pritt and Raese $(1992,1995)$. The manual identifies and documents practices and standard operating procedures for activities that affect data quality from the time of receipt of the samples at the NWQL to the reporting of results.

Field personnel at the INEEL participate in the National Field Quality Assurance Tests administered annually by the USGS (Erdmann and Thomas, 1985, p. 110-115). These tests are used to evaluate performance in making field measurements for $\mathrm{pH}$, specific conductivity, and alkalinity.

Part of the QA/QC program, from 1989 through 1995 consisted of sending QA replicate samples, along with water-quality samples, and blank samples to the laboratories for analyses of specific constituents. Identification, source, and description of source solution and equipment blanks are presented in table 2. Analytical results of replicate pairs of samples were compared for statistical equivalence; the analytical results and results of the statistical comparisons are presented in tables 3 through 12. Analytical results of blank samples are presented in tables 13 through 20 .

\section{Sample Collection and Analytical Methods}

The methods used for sample collection and analyses of the constituents of interest generally followed the guidelines established by the USGS (Goerlitz and Brown, 1972; Stevens and others, 1975; Thatcher and others, 1977; Wood, 1981; Claassen, 1982; W.L. Bradford, USGS written commun., 1985; 
Table 1. Laboratories and respective analyses for the water-quality samples from selected wells and springs, eastern Snake River Plain, 1989 through 1995

\begin{tabular}{|c|c|}
\hline Laboratory & Quantitative analysis \\
\hline National Water Quality Laboratory & $\begin{array}{l}\text { Inorganic constituents } \\
\text { dissolved major ions (calcium, magnesium, sodium, potassium, sulfate, } \\
\text { chloride, fluoride, bromide, and silica) } \\
\text { dissolved nutrients (nitrite, nitrite plus nitrate, ammonia, and } \\
\text { orthophosphate) } \\
\text { dissolved cyanide } \\
\text { trace elements (dissolved aluminum, arsenic, barium, beryllium, cadmium, } \\
\text { chromium, hexavalent chromium, cobalt, copper, iron, lead, lithium, } \\
\text { manganese, mercury, molybdenum, nickel, selenium, silver, strontium, } \\
\text { vanadium, and zinc; and total chromium) } \\
\text { Gross radioactivity and radionuclides } \\
\text { dissolved and suspended gross alpha } \\
\text { dissolved and suspended gross beta } \\
\text { radon-222 } \\
\text { radium-226 and radium-228 } \\
\text { uranium } \\
\text { strontium-90 } \\
\text { tritium } \\
\text { gamma radiation } \\
\text { Organic constituents } \\
\text { dissolved organic carbon } \\
\text { anionic surfactants as methylene blue active substances, } \\
\text { volatile organic compounds } \\
\text { pesticides } \\
\text { gross polychlorinated biphenyls } \\
\text { gross polychlorinated naphthalenes } \\
\text { Stable-isotope ratios } \\
\text { hydrogen-2/hydrogen-1, oxygen-18/oxygen-16, carbon-13/carbon-12, } \\
\text { sulfur-34/sulfur-32, and nitrogen-15/nitrogen-14 }\end{array}$ \\
\hline $\begin{array}{l}\text { Idaho Department of Health and Welfare } \\
\text { Laboratory }\end{array}$ & $\begin{array}{l}\text { Inorganic constituents } \\
\text { total major ions (calcium, magnesium, sodium, potassium, sulfate, chloride, } \\
\text { fluoride, and silica) } \\
\text { dissolved or total trace elements, or both (aluminum, arsenic, barium, } \\
\text { beryllium, cadmium, chromium, cobalt, copper, iron, lead, lithium, } \\
\text { manganese, mercury, molybdenum, nickel, selenium, silver, strontium, } \\
\text { vanadium, and zinc) } \\
\text { Organic constituents } \\
\text { volatile organic compounds }\end{array}$ \\
\hline $\begin{array}{l}\text { Idaho State University Environmental } \\
\text { Monitoring Laboratory }\end{array}$ & $\begin{array}{l}\text { Gross radioactivity and radionuclides } \\
\text { gross alpha } \\
\text { gross beta } \\
\text { strontium-90 } \\
\text { tritium } \\
\text { gamma radiation }\end{array}$ \\
\hline
\end{tabular}


Wershaw and others, 1987; Fishman and Friedman, 1989; Faires, 1992; and Fishman, 1993). Water samples analyzed by the IDHWL were collected in accordance with procedures described by W. Baker, J. Dodds, and B. Ellis (IDHWL, written communs., 1991). Water samples analyzed by the ISU laboratory were collected in accordance with laboratory requirements specified by the Director of the Environmental Monitoring Program at ISU.

Nine of the irrigation wells discharged into stilling ponds and were sampled near the discharge pipes. The rest of the irrigation wells and the public-supply well were sampled from spigots in discharge lines near pumps. Domestic, dairy, and commercial wells were sampled from spigots closest to pumps. Stock wells were sampled at water-tank inlet pipes. Observation wells were sampled at well heads. All the wells either were pumping on arrival of the sampling team or were started on arrival and, when possible, pumped long enough to ensure that pressure tanks and pumping systems were thoroughly flushed as evidenced by stable $\mathrm{pH}$, specific conductance, and temperature measurements. The five springs were sampled as near the sources as possible by collecting a grab sample from an area of moving water.

Chemical and physical characteristics measured at the sampling sites during all three sampling rounds included $\mathrm{pH}$, specific conductance, and water temperature. Alkalinity and dissolved-oxygen determinations were added in rounds two and three. After collection, and preservation when required, the samples were sealed with laboratory film.

Containers were labeled at each location to avoid sample mix-up. Samples collected for analyses by the NWQL were packed into ice chests for shipment. Samples collected for analyses by the IDHWL and the ISU laboratory were stored in coolers or sealed boxes, as appropriate, until they were hand delivered to the laboratories.
Conditions at the sampling sites during sample collection were recorded in a field logbook. Chain-of-custody records were used to track the samples from the time of collection until delivery to the analyzing laboratories. These records are available for inspection at the USGS Project Office at the INEEL.

\section{QUALITY-ASSURANCE/QUALITY- CONTROL SAMPLES, REPLICATE PAIRS OF SAMPLES}

The guidelines for water-sample collection are being updated as needed in accordance with new safety and environmental regulations and improved analytical procedures. Replicate pairs of samples always were collected sequentially as follows: for each type of constituent, first the water-quality sample was collected, then the QA replicate sample was collected, until all the required containers were filled. Each water-quality sample and QA replicate sample was labeled and preserved at the sampling site to avoid sample mix-up.

Site identifiers for the 55 sampling sites and the QA replicate samples were established before the initial sampling began. During each sampling round, each of the five site identifiers established for the QA replicate samples (MV-8, 28, 34, 44, and 60) was used. Because these were blind replicates, there was no correlation between the site identifiers of the waterquality samples and those of the QA replicate samples. Results from blind replicates can indicate whether the laboratory, given variation in equipment, materials, or analysts, can reproduce results. This type of $Q A$ sample also can indicate variability of factors related to the collection process, such as ambient conditions at the site, field personnel, field-measurement instruments, and sampling equipment. 


\section{Statistical Comparisons of Replicate Pairs of Samples}

Since an analytical result is a best estimate of the concentration of the constituent of interest, an uncertainty is always associated with that estimate. Although uncertainties may be determined by different methods and designated by different terms, all can be considered estimates of the precision associated with the results. In this report, the uncertainty is designated as the standard deviation.

If the standard deviations are known, it is possible to determine, within a specified confidence level, whether the results of a replicate pair of samples are statistically equivalent. When the standard deviations are unknown, approximations of the standard deviations can be used for the statistical comparison. The comparison can be made using an adaptation of the equation to determine the standard deviate $(Z)$ or the number of standard deviations the variable deviates from the mean (Volk, 1969 , p. 55), where $Z$ is the ratio of the absolute value of the difference of the two results and the square root of the sum of the squares of the standard deviations (the pooled standard deviation). In that way, a comparison can be made of two analytical results on the basis of the precision, or an approximation of the precision, associated with each of the results:

$$
Z=\frac{|x-y|}{\sqrt{\left(s_{x}\right)^{2}+\left(s_{y}\right)^{2}}}
$$

where

$\mathrm{x}$ is the result of the water-quality sample,

$y$ is the result of the QA replicate sample,

$s_{x}$ is the standard deviation of $x$, and

$s_{y}$ is the standard deviation of $y$.

When the population is distributed normally and the standard deviation is known, the analytical results of replicate pairs can be considered statistically equivalent at the 95-percent confidence level if the $\mathrm{Z}$-value is less than or equal to 1.96. When the population is not distributed normally or an approximation of the standard deviation is used, a Z-value less than or equal to 1.96 must be considered a guide when testing for equivalence. At the 95percent confidence level, the probability of error is 0.05 . In other words, when a Z-value is less than or equal to 1.96 , the results are within approximately two standard deviations of each other. Equation 1 is essentially the equation used to compare replicate data in the USGS protocol for collection and processing of surface-water samples (Horowitz and others, 1995, p. 36).

Instead of setting a value that is approximately equal to two standard deviations as a test of equivalence, the level of significance, or $p$-value, which indicates the weight of the evidence to reject the null hypothesis, which is $x \pm s_{x}=y \pm s_{y}$, may be determined. The null hypothesis is tested using the $Z$-value as the test statistic. The $Z$-value is calculated by using equation 1 . Then the $p$-value is determined by referring to table 21 . Assuming the distribution is normal, the $p$-value is the area under the curve for the $Z$-value. The greater the $Z$-value, the smaller the $p$-value and the more likely that the results of the replicate pair are not equivalent, and the null hypothesis will be rejected. When $Z=1.96$, the $p$-value $=$ 0.0250 for a one-tailed test and 0.0500 for a two-tailed test (table 21). This shows that these $p$-values are equivalent to the 95 -percent confidence level and $\alpha=0.05$, where $\alpha$ is the probability that the null hypothesis will be rejected when true.

\section{Inorganic Constituents}

Equation 1 cannot be applied directly to results when no standard deviations are reported. The analyses for inorganic constituents that were done at the NWQL were not reported with standard deviations; therefore, approximations of standard deviations were used. The approximations were determined 
using information available through the USGS Branch of Technical Development and Quality Systems (BTD\&QS), formerly the Branch of Quality Assurance.

The USGS administers an extensive interlaboratory comparison program in which approximately 150 laboratories are evaluated on the basis of the results of their analyses of standard reference water samples (SRWS) (Long and Farrar, 1993). The data from the interlaboratory comparison program, or the SRWS program, are used by the BTD\&QS to derive linear regression equations that allow the calculation of an approximation of the standard deviation, a most probable deviation (MPD), at any concentration for most analyses.

The BTD\&QS conducts the Blind Sample Program (BSP) in which SRWS, disguised as environmental samples, are submitted to the NWQL for analyses. The BSP data are evaluated using control charts prepared with the MPD's calculated from the regression equations formulated from the SWRS program. A report by Maloney and others (1993) describes the BSP, evaluates the analytical results, and presents the linear regression equations and control and precision charts. The BSP data and control and precision charts are stored in the QADATA program that is available through the USGS computer network (Lucey, 1990, p. 1).

At the INEEL project office, the linear regression equations are used to determine if the analytical results of the replicate pairs are statistically equivalent by calculating an MPD for each result and substituting the MPD for the standard deviation in equation 1 . Because these are approximate standard deviations, the Z-value of 1.96 must be considered a guide when testing for equivalence. The results of replicate pairs of samples analyzed for inorganic constituents and the $Z$-values for each replicate pair are included in tables 3 through 12.

The analytical results were less than the MRL for many samples. If the results of both samples of the replicate pair were less than the $M R L$, the results were considered equivalent and the $\mathrm{Z}$-value was reported as a zero. If, however, only one of the results was less than the MRL, one of two approaches was taken.

First, if one result was less than the MRL and the other exceeded the MRL, the numerical value and the MPD of the numerical value of the MRL were substituted in equation 1 for the result at the MRL. For example, the results of analyses for ammonia in the replicate pair collected at MV- 55 on July 26,1995 , were $0.03 \mathrm{mg} / \mathrm{L}$ and $<0.015 \mathrm{mg} / \mathrm{L}$ (table 4 ). Using the MPD calculated with the QADATA linear regression equations, the results and MPD were $0.03 \pm 0.02 \mathrm{mg} / \mathrm{L}$ and $<0.015 \pm 0.02 \mathrm{mg} / \mathrm{L}$, respectively. The Z-value, calculated using equation 1, equaled 0.64 . It was less than 1.96 ; therefore, it was within the 95-percent confidence interval. The results of the replicate pair were equivalent and no comment appears in the "Remark" column. If the Z-value had been greater than 1.96, an " $\mathrm{N}$ " would have appeared in the "Remark" column signifying that the results would not have been equivalent.

Second, if one result was less than the MRL and the other was at the MRL, the MPD of the result at the MRL was calculated using the linear regression equation for that analysis. In these cases, however, it was impractical to use equation 1 because the $Z$-value would always equal zero. Therefore, to compare the two results using the precision associated with them, the MPD was multiplied by 1.96 . If the range of the MPD included zero, the results were equivalent because any result less than the MRL was included in the 95-percent confidence interval. If the range did not include zero, as often is the case when the MPD is relatively small, equivalency could not be deter- 
mined. For example, the results of analyses for vanadium in the replicate pair collected at MV-24 on August 12, 1991, were $6 \mu \mathrm{g} / \mathrm{L}$ and $<6 \mu \mathrm{g} / \mathrm{L}$ (table 5). Using the MPD of $2 \mu \mathrm{g} / \mathrm{L}$ calculated with the QADATA linear regression equations, the results and MPD were $6 \pm 2 \mu \mathrm{g} / \mathrm{L}$ and $<6 \pm 2 \mu \mathrm{g} / \mathrm{L}$, respectively. Therefore, the result of $6 \mu \mathrm{g} / \mathrm{L}$ would have a MPD of $1.96 \times 2 \mu \mathrm{g} / \mathrm{L}$ at the 95 -percent confidence level: $6 \pm 4 \mu \mathrm{g} / \mathrm{L}$. The range did not include zero and an "I" appears in the "Remark" column, signifying that equivalence was indeterminate. If the range had included zero, no comment would have appeared in the "Remark" column.

\section{Gross Radioactivity and Radionuclides}

The use of equation 1 was straightforward in determining if the results of radiochemical analyses of a replicate pair of samples were equivalent. The NWQL reported radiochemical results and values for a two-sigma precision estimate (2SPE). The ISU laboratory reported radiochemical results and values for two standard deviations, except in 1993, when it reported results and only one standard deviation. When 2SPE or two standard deviations were reported, the value was divided by two to compute the one standard deviation required by equation 1 . The results of the analyses for gross radioactivity and radionuclides in replicate pairs and the Z-values are listed in tables 6 and 7.

Because of differences in the radiochemical analyses, data from the ISU laboratory could not be compared with data from the NWQL. For example, the NWQL analyzed samples for dissolved and suspended gross radioactivity; the ISU laboratory, for total gross radioactivity. Furthermore, the ISU laboratory method detection limit and uncertainties for radiochemical analyses were much greater than those of the NWQL. Therefore, although the analytical results from the two laboratories would be considered equivalent if compared statistically, they were not comparable and no conclusions could be made concerning precision and accuracy of the two laboratories.

\section{Organic Constituents}

Organic constituents were not included in the BSP; therefore, the standard deviations used for DOC analyses were calculated from the relative standard deviations (RSD) reported by Wershaw and others (1987, p. 15-16); for MBAS, by the NWQL Services Catalog (Pritt and Jones, 1989, p. 5-45); for VOC's, by Rose and Schroeder (1995, p. 18-23); and for pesticides, by Wershaw and others (1987, p. 30, 40, 43, and 46) and Zaugg and others (1995, p. 23-33). The VOC's and pesticides, Chemical Abstract Service (CAS) Registry numbers, MRL's, and years analyzed are listed in tables 22 and 23. The sites and years sampled are listed in table 24 .

The results of the analyses for DOC and MBAS in replicate pairs and the $Z$-values are presented in table 8 . Concentrations of 8 VOC's and 10 pesticides were at or exceeded the MRL's in either the water-quality or the QA replicate sample of some sample pairs. The results and Z-values for only those sample pairs are presented in tables 9 and 10. The results of analyses for gross polychlorinated compounds in replicate pairs and the $Z$-values are presented in table 11 . If analytical results of the pair were not statistically equivalent, an "N" appears in the "Remark" column. If equivalence could not be determined, an " $\mathrm{T}$ " appears in the "Remark" column, signifying that equivalence was indeterminate. If the results of both samples of a replicate pair were less than the MRL, the results were considered equivalent and the $Z$-value was reported as a zero.

\section{Stable Isotopes}

The analyses for stable isotopes in waterquality samples involve determining ratios of 
stable isotopes in a sample relative to those in a standard. Results are reported in delta $(\delta)$ notation, which is the parts-per-thousand difference between a sample and a standard: hydrogen-2/hydrogen-1 $\left({ }^{2} \mathrm{H}\right)$, oxygen-18/ oxygen-16 $\left(\delta^{18} \mathrm{O}\right)$, carbon-13/carbon-12 $\left(\delta^{13} \mathrm{C}\right)$, sulfur-34/sulfur-32 $\left(\delta^{34} \mathrm{~S}\right)$, and nitrogen-15/nitrogen-14 $\left(\delta^{15} \mathrm{~N}\right)$. Results of replicate pairs of samples analyzed for stable isotopes were not reported with a standard deviation; however, precision-estimate values are listed in the NWQL Services Catalog (Timme, 1994) and updated by Kendall and Carmody (U.S. Geological Survey, oral and written communs., 1994-1996). The precision estimate was substituted into equation 1 for the standard deviation to determine statistical equivalence. Results and precision estimates for the stable isotopes in replicate pairs and the $\mathrm{Z}$-values are listed in table 12.

\section{Summary of Statistical Comparisons of Replicate Pairs of Samples}

The statistical comparisons of the data indicated that 95 percent of the analytical results of replicate pairs were equivalent. Of the major ion analyses, 99 percent were equivalent; nutrients and cyanide, 92 percent; trace elements, 98 percent; gross radioactivity and radionuclides (NWQL and ISU), 81 percent; organic constituents, 99 percent; and stable isotopes, 88 percent. Ninety percent or more of the results for each constituent were equivalent, except those for orthophosphate, aluminum, vanadium, zinc, gross alpha radioactivity, gross beta radioactivity, radon-222, radium-226, strontium-90, tritium, gamma radiation, MBAS, $\delta^{13} \mathrm{C}$, and $\delta^{15} \mathrm{~N}$. Lack of equivalence between results of replicate pairs indicates a problem. Because many factors, such as field methods, ambient conditions, laboratory procedures, and nonanalytical errors can affect precision, the source of the inconsistency cannot always be pinpointed.
The following sections summarize the results of statistical comparisons for each constituent. Graphical summaries are provided in figures 3 through 9 .

\section{Inorganic Constituents}

Major ions. Ten replicate pairs of samples were analyzed by the NWQL for the following dissolved major ions: calcium, magnesium, sodium, potassium, sulfate, chloride, fluoride, bromide, and silica (table 3 ). For all but the bromide analyses, Z-values were calculated using the analytical results and the MPD's determined with the regression equations formulated by the BTD\&QS from the SRWS program data. Because the bromide analysis was not included in the BSP, an RSD of 15 percent (Pritt and Jones, 1989, p. 5-6) was used in equation 1.

All of the analytical results of the replicate pairs analyzed by the NWQL for dissolved major ions were equivalent except results for potassium in one pair. The $Z$-values indicated that 89 results, or 99 percent of the results, were equivalent (fig. 3 ).

At some sampling sites, replicate pairs of samples also were collected to be analyzed by the IDHWL for total, rather than dissolved, major ions. The total major ions and the number of replicate pairs follow: calcium, 2; magnesium, 2; sodium, 3; potassium, 2; sulfate, 3; chloride, 3; fluoride, 3; and silica, 2 (table 3). Only the water-quality sample of one replicate pair (MV-40) was analyzed for total sodium, sulfate, chloride, and fluoride.

Because IDHWL did not report the results with a precision statement, they could not be compared statistically with results from the NWQL; however, results of the samples of the replicate pairs analyzed by the NWQL were similar to the results of the corresponding samples analyzed by the IDHWL, except for the 


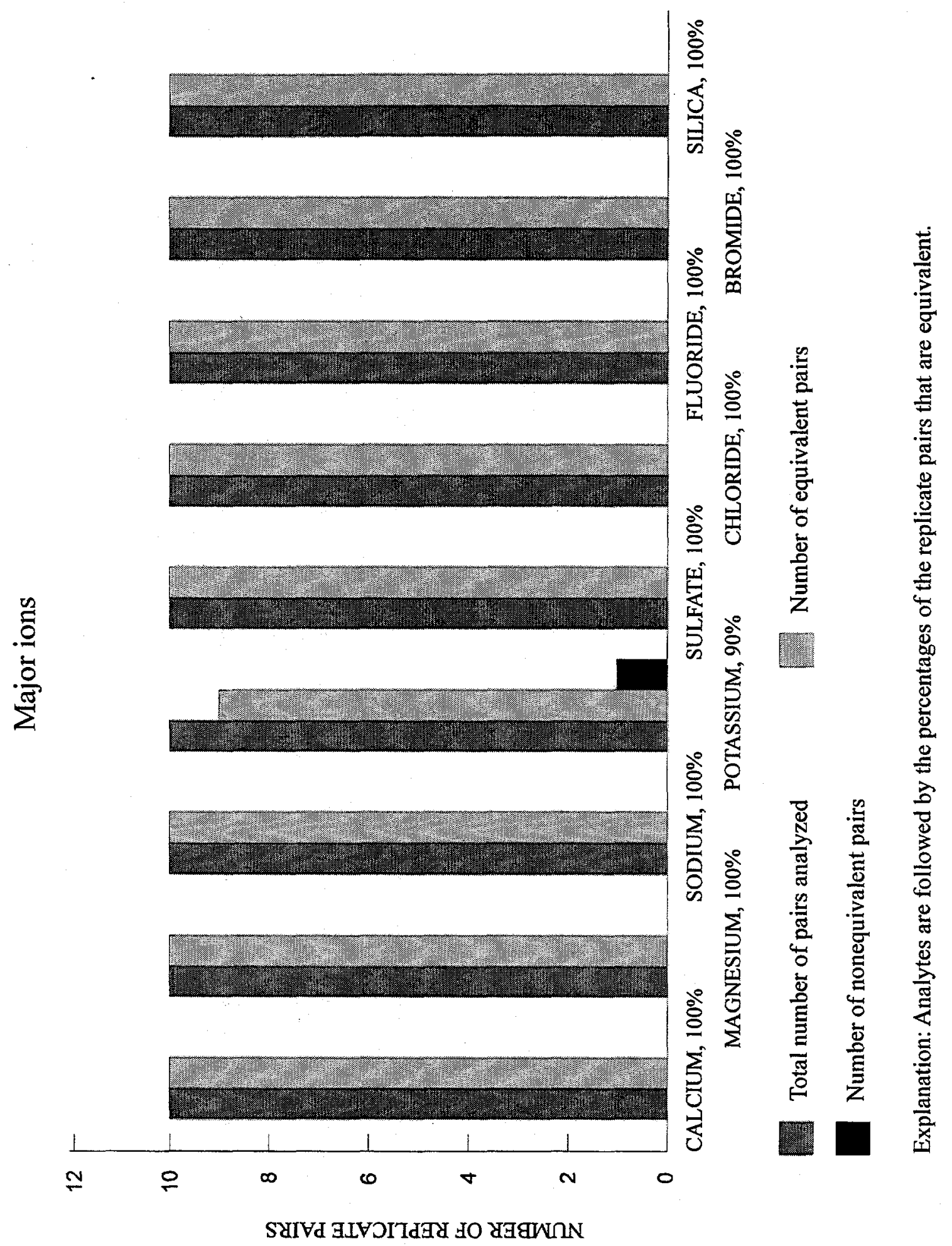

Figure 3. Results of statistical comparisons of replicate pairs of samples analyzed for major ions. 


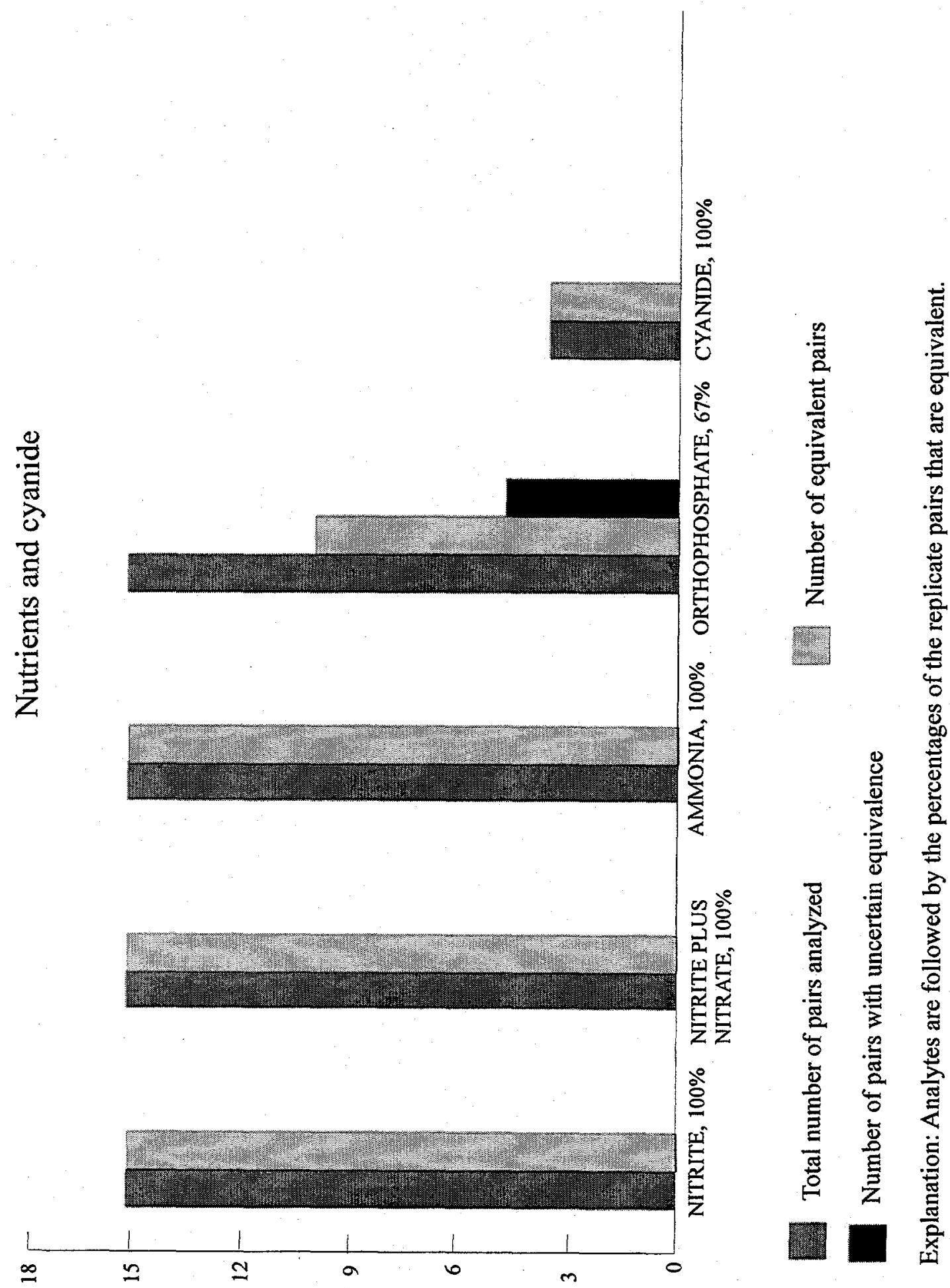

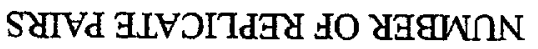

Figure 4. Results of statistical comparisons of replicate pairs of samples analyzed for nutrients and cyanide. 


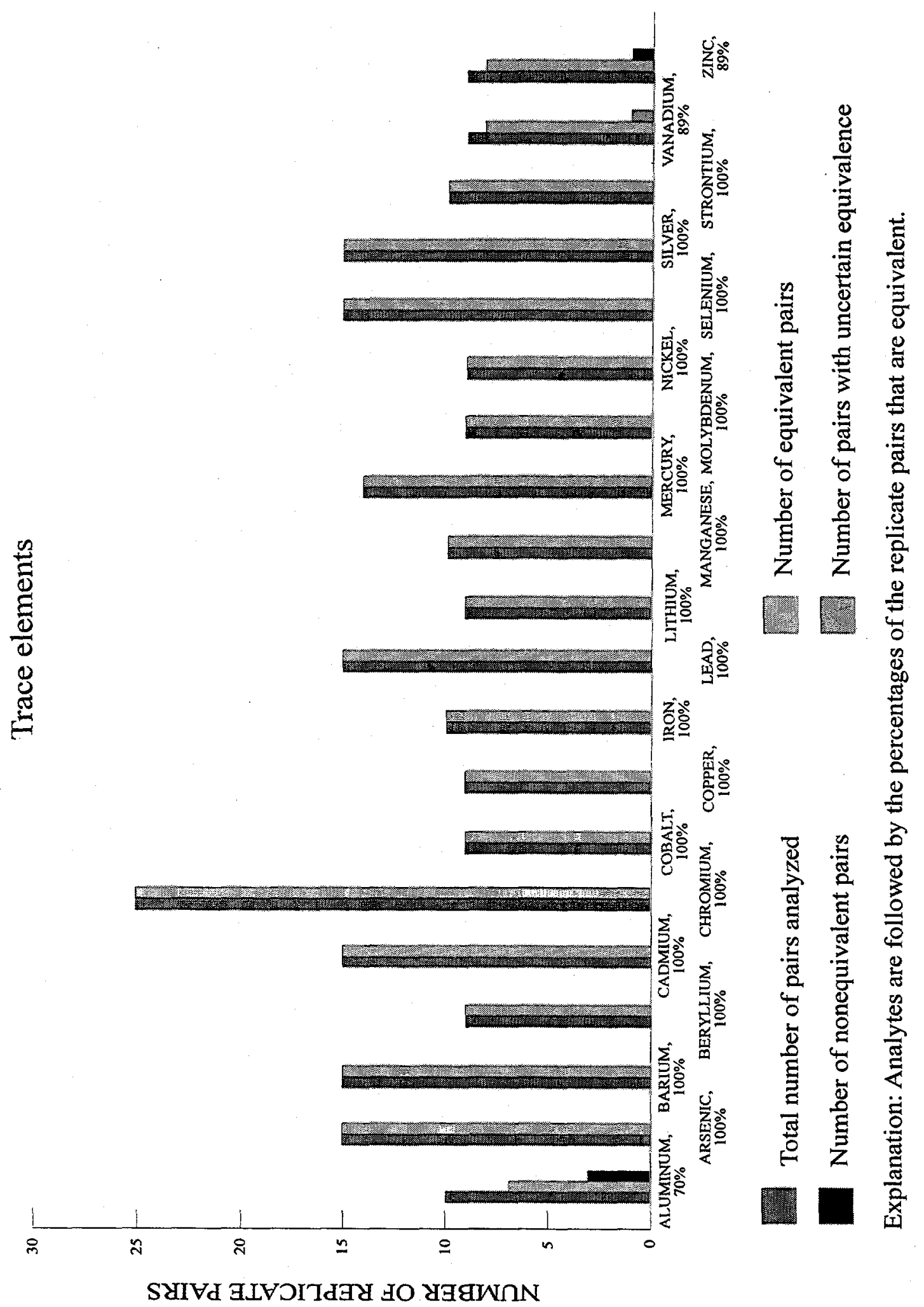

Figure 5. Results of statistical comparisons of replicate pairs of samples analyzed for trace elements. 


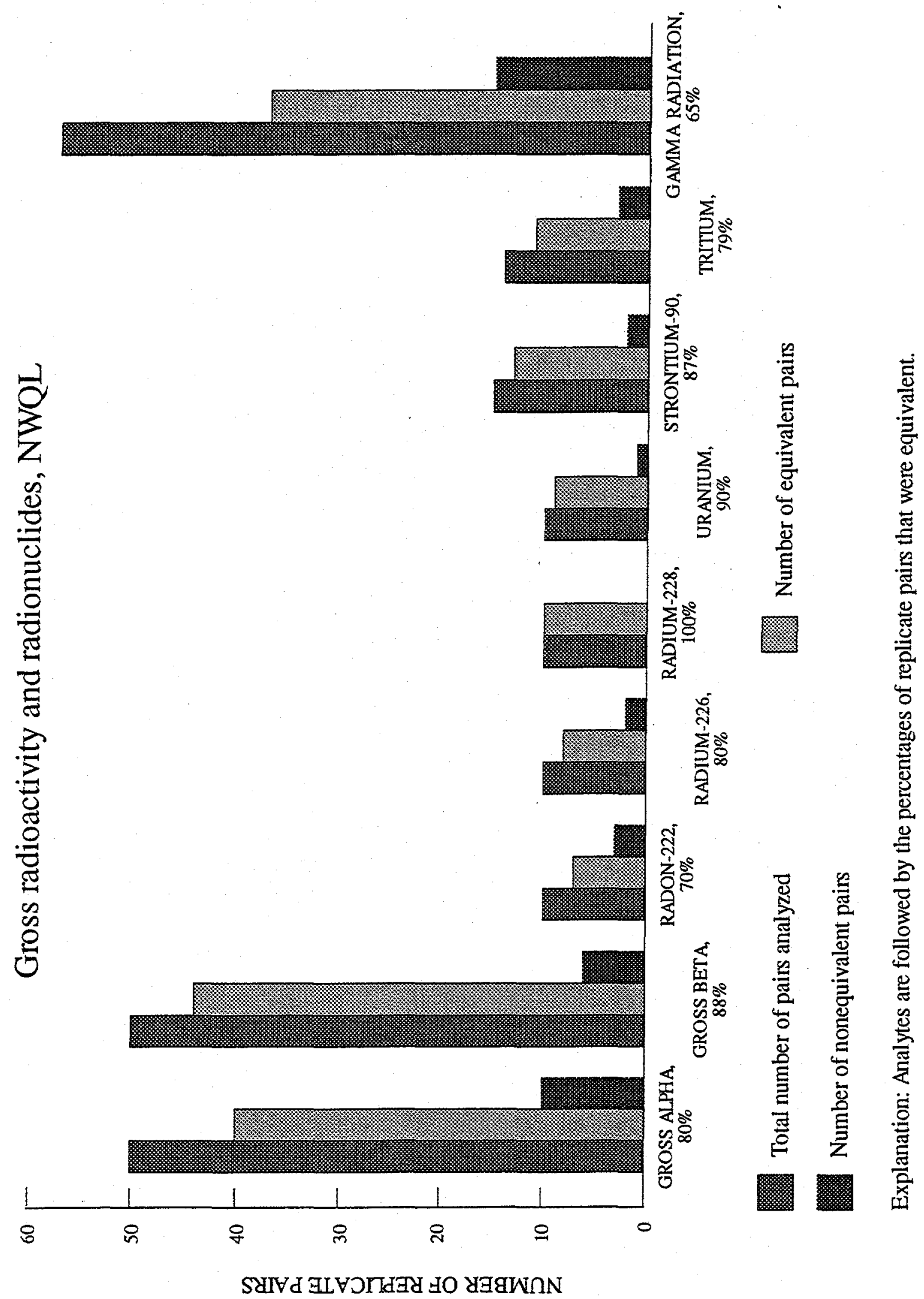

Figure 6. Results of statistical comparisons of replicate pairs of samples analyzed for gross radioactivity and radionuclides, National Water Quality Laboratory. 


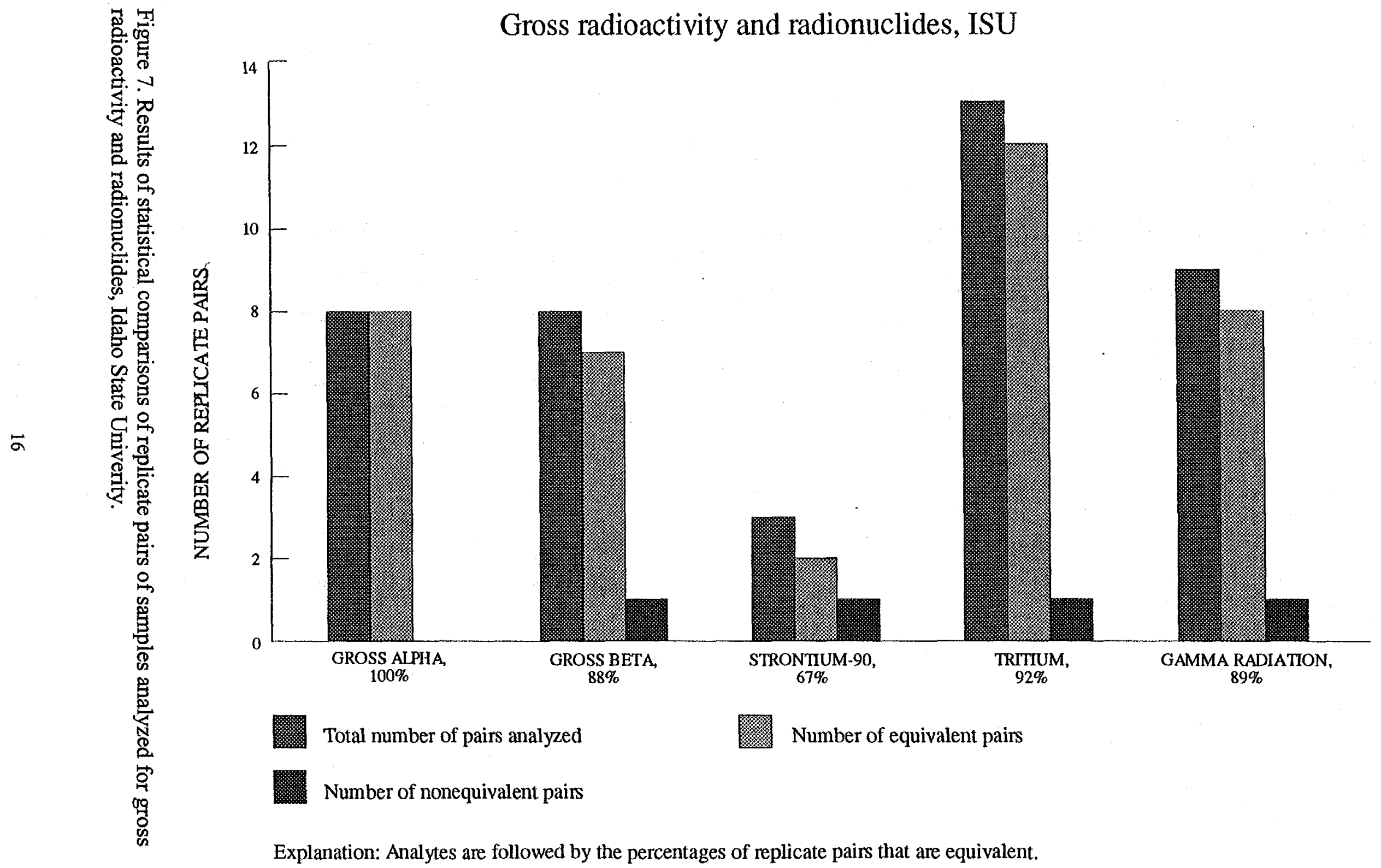




\section{Organic constituents}

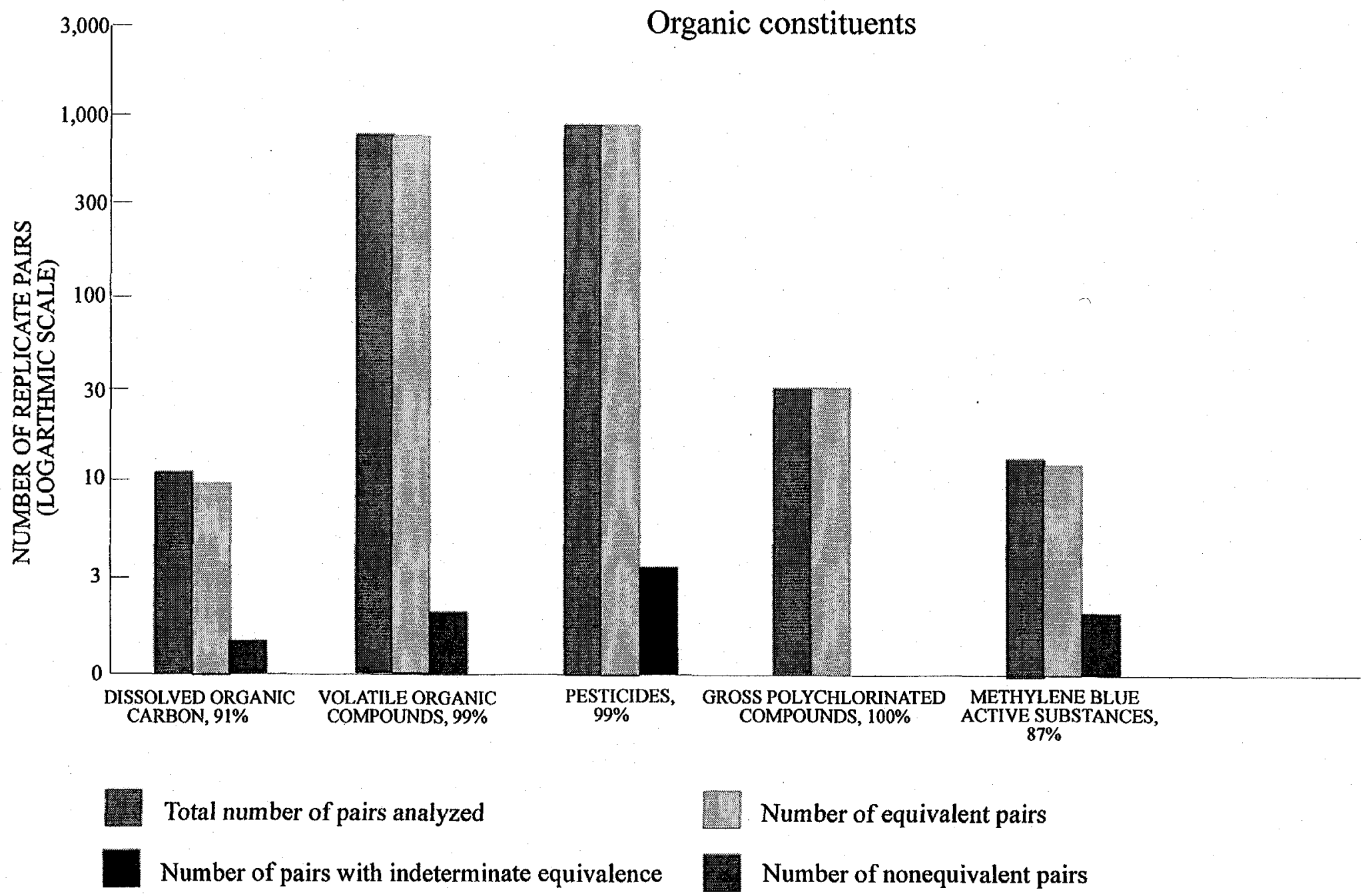

Explanation: Analytes are followed by the percentages of the replicate pairs that are equivalent. 


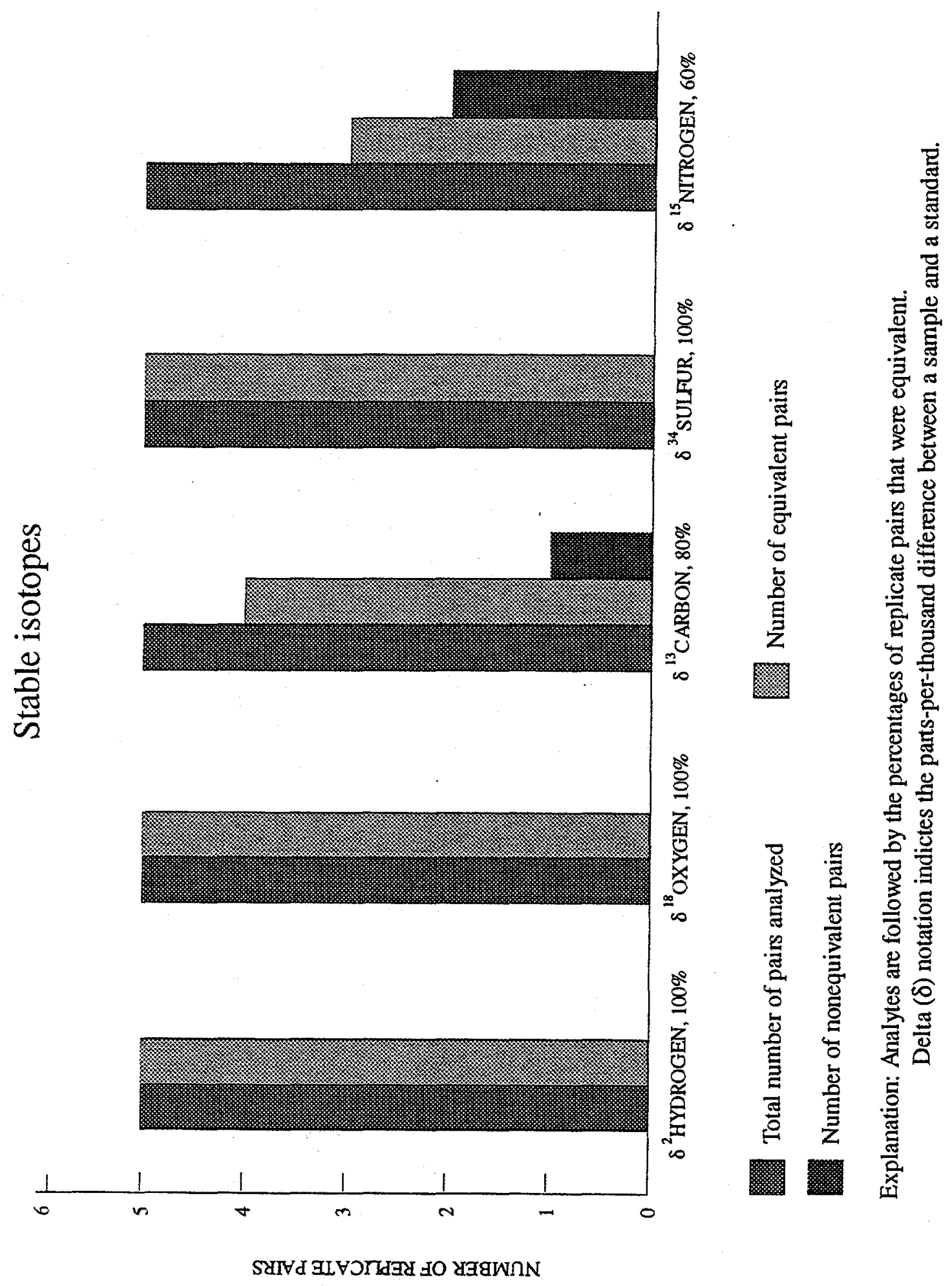

Figure 9. Results of statistical comparisons of replicate pairs of samples analyzed for stable isotopes. 
results for chloride in one replicate pair [MV-36(60)] in 1992. Conclusions drawn from comparisons between concentrations of dissolved and total constituents are not always valid; however, the similarity of the results of the replicate pairs and the single water-quality sample analyzed by the IDHWL to those analyzed by the NWQL appear to validate the sampling methods and verify the accuracy of analyses.

Nutrients and cyanide. Fifteen replicate pairs of samples were analyzed by the NWQL for the following dissolved nutrients: nitrite, nitrite plus nitrate, ammonia, and orthophosphate; four replicate pairs were analyzed for dissolved cyanide (table 4). All the Z-values, except those for the nitrite and cyanide analyses, were calculated using MPD's determined with the regression equations formulated by the BTD\&QS from the SRWS program data. Analyses for these two constituents were not included in the BSP, but the results of each replicate pair were numerically the same and were considered equivalent.

For the nutrient analyses, Z-values indicated that equivalence of results for 5 replicate pairs for orthophosphate was indeterminate and results of 55 pairs, or 92 percent of the results, were equivalent; for the cyanide analyses, results of 4 pairs, or 100 percent of the results, were equivalent. Although the orthophosphate analyses were included in the BSP, the concentrations determined in the BSP were higher than those of the replicate pairs in this report; therefore, equivalence was indeterminate for the replicate pairs analyzed for orthophosphate that were less than $0.03 \mathrm{mg} / \mathrm{L}$.

Trace elements. Replicate pairs of samples were analyzed by the NWQL for dissolved trace elements. The trace element and the number of replicate pairs follow: aluminum, 10 ; arsenic, 15; barium, 15; beryllium, 9; cadmium, 15; chromium, 25; cobalt, 9; copper, 9; iron, 10; lead, 15; lithium, 9; manganese, 10; mercury, 14; molybdenum, 9; nickel, 9; selenium, 15; silver, 15; strontium, 10; vanadium, 9; and zinc, 9 (table 5). The Z-values were calculated using MPD's determined with the regression equations formulated by the BTD\& QS from the SRWS program data.

All of the results of the replicate pairs analyzed by the NWQL for trace elements were equivalent except the following, which are listed with the percentage that were equivalent or indeterminate, or both: aluminum, 70 percent equivalent; vanadium, 89 percent equivalent and 11 percent indeterminate; and zinc, 89 percent equivalent. The $Z$-values indicated that 4 results were not equivalent, 1 result was indeterminate, and 246 results, or 98 percent of the results, were equivalent.

Statistical comparisons of the aluminum analyses indicated that results of 3 replicate pairs were not equivalent and results of 7 pairs, or 70 percent of the results, were equivalent. Only ten replicate pairs were analyzed for aluminum; therefore, additional information from the BSP was used to support the conclusions. The information from the QADATA program that is available through the USGS computer network (Lucey, 1990) shows that the aluminum analyses of the BSP samples have displayed high variability; therefore, the BTD\& QS has reset the control limits to three sigma. The MPD's used in the statistical comparisons of the replicate pairs were multiplied by 1.5 to adjust for the higher control limits.

Equivalency of results for vanadium in one of the nine replicate pairs analyzed for vanadium was indeterminate. The results of the replicate pair [MV-24(28)] were at the MRL and less than the MRL and the MPD's of the results were relatively small.

Nine replicate pairs were analyzed for dissolved zinc; results of one replicate pair [MV-36(60)] were not equivalent. The results were $<3 \mu \mathrm{g} / \mathrm{mL}$ for the water-quality sample 
and $30 \mu \mathrm{g} / \mathrm{mL}$ for the QA replicate sample. The results of both samples in the replicate pair analyzed by the IDHWL for total zinc were $<2 \mu \mathrm{g} / \mathrm{mL}$ (table 5); a more recent analytical value for dissolved zinc at the same site was $4 \mu \mathrm{g} / \mathrm{mL}$ (Bartholomay and others, 1996, p. 17). These lower values indicate that the result of the water-quality sample of the replicate pair [MV-36(60)] was probably accurate. The reason for the large difference between results of each sample of the replicate pair could not be determined.

At some sampling sites, replicate pairs of samples also were collected to be analyzed by the IDHWL for dissolved and total trace elements. The trace elements and number of replicate pairs follow: aluminum, 2 dissolved; arsenic, 3 dissolved and 1 total; barium, 3 dissolved and 1 total; beryllium, 3 dissolved and 1 total; cadmium, 4 dissolved and 1 total; chromium, 3 dissolved and 1 total; cobalt, 2 dissolved; copper, 2 dissolved; iron, 2 dissolved; lead, 3 dissolved and 1 total; lithium, 2 dissolved; manganese, 2 dissolved; mercury, 3 dissolved and 1 total; molybdenum, 2 dissolved; nickel, 2 dissolved; selenium, 3 dissolved and 1 total; silver, 3 dissolved and 1 total; strontium, 2 dissolved; vanadium, 2 dissolved; and zinc, 2 dissolved.

Only the water-quality sample of one replicate pair [MV-40(34)] was analyzed for dissolved cadmium and dissolved and total arsenic, barium, beryllium, chromium, lead, mercury, selenium, and silver. Although IDHWL did not report the results with a precision statement and they could not be compared statistically, most of the analytical results were less than the MRL's; and, therefore, they were considered equivalent. With the exception of the MRL's for cadmium, copper, molybdenum, nickel, and silver, the MRL's for trace elements used by the IDHWL were much greater than those of the NWQL. Therefore, the analytical results of the two laboratories could not be compared.

\section{Gross radioactivity and radionuclides}

Gross alpha radioactivity. Thirty replicate pairs of samples were analyzed by the NWQL for dissolved gross alpha radioactivity; 20 of those replicate pairs also were analyzed for suspended gross alpha radioactivity (table 6). At the NWQL, each sample was prepared and counted on a low-background alpha-beta counter; the results were reported both as thorium-230 and as natural uranium. The $Z$-values indicated that 10 replicate pairs analyzed for gross alpha radioactivity were not equivalent and 40 pairs, or 80 percent of the results, were equivalent.

The results of four replicate pairs analyzed for dissolved gross alpha radioactivity, both as thorium-230 and as natural uranium, were not equivalent. The results of one of those replicate pairs [MV-61(60)] that also was analyzed for suspended gross alpha radioactivity, both as thorium-230 and as natural uranium, were not equivalent.

The NWQL contracted with three laboratories during three different time periods (1989, 1990-93, and 1994-present) to perform most radiochemical analyses, including analyses for gross alpha radioactivity. Eighty percent of the results of replicate pairs that were not equivalent were collected and analyzed in 1989.

Although the laboratory that analyzed the samples in 1989 used smaller precision estimates than the analyzing laboratories in 1990 through 1995, and smaller precision estimates lead to larger $Z$-values when using equation 1 , close examination of the data shows that use of larger precision estimates, similar to those used by the laboratories during 1990-95, would not result in a significant increase in the number of equivalent replicate pairs. The same field methods were used during 1989-93; and except for the eight results in 1989, all the results from 1989-93 were equivalent. 
At eight of the sampling sites, replicate pairs also were collected for analyses by the ISU laboratory for total gross alpha radioactivity as americium-241. The $\mathrm{Z}$-values indicated that results of the 8 replicate pairs, or 100 percent of the results, were equivalent.

Gross beta radioactivity. Thirty replicate pairs of samples were analyzed by the NWQL for dissolved gross beta radioactivity; 20 of those replicate pairs also were analyzed for suspended gross beta radioactivity (table 6). At the laboratory, each sample was prepared and counted on a low-background alpha-beta counter and the determinations were reported both as cesium-137 and as strontium-90/ yttrium-90. The $Z$-values indicated that 6 replicate pairs analyzed for gross beta radioactivity were not equivalent and 44 pairs, or 88 percent of the results, were equivalent.

The results of two replicate pairs analyzed for dissolved gross beta radioactivity, both as cesium-137 and as strontium-90/yttrium-90, were not equivalent. Results of two other replicate pairs analyzed for dissolved gross beta radioactivity, as strontium-90/yttrium-90, were not equivalent. All the results of replicate pairs analyzed for suspended gross beta radioactivity, as both isotopes, were equivalent.

The NWQL contracted with the same laboratories for gross beta radioactivity analyses as for gross alpha radioactivity analyses during the same time periods. The reason for the lack of equivalence of the results is unknown.

At eight of the sampling sites, replicate pairs also were collected for analyses by the ISU laboratory for total gross beta radioactivity as cesium-137. The Z-values indicated that results of 1 replicate pair were not equivalent and results of 7 pairs, or 88 percent of the results, were equivalent.

Radon-222. Ten replicate pairs of samples were analyzed for radon-222 by the NWQL (table 6). The Z-values indicated that results of 3 replicate pairs were not equivalent and results of 7 pairs, or 70 percent of the results, were equivalent.

Radon-222 readily migrates in the presence of moving water because it is a gas. In general, radon-222 data are hard to interpret because of the short half-life of the radionuclide and the complex nature of factors affecting its concentrations (Durrance, 1986, p. 219).

Radium-226. Ten replicate pairs of samples were analyzed for radium-226 by the NWQL (table 6). The Z-values indicated that results of 2 replicate pairs were not equivalent and 8 pairs, or 80 percent of the results, were equivalent.

Radium-228. Ten replicate pairs of samples were analyzed for radium-228 by the NWQL (table 6). The Z-values indicated that 100 percent of the results were equivalent.

Uranium. Ten replicate pairs of samples were analyzed for uranium by the NWQL (table 6). The Z-values indicated that results of 1 replicate pair were not equivalent and 9 pairs, or 90 percent of the results, were equivalent.

Strontium-90. Fifteen replicate pairs of samples were analyzed for strontium- 90 by the NWQL (table 6). The Z-values indicated that results of 2 replicate pairs were not equivalent and 13 pairs, or 87 percent of the results, were equivalent. Although the concentration in one sample of each of the two nonequivalent replicate pairs both collected and analyzed in 1989 was greater than three times the analytical uncertainty, it is unlikely that strontium-90 was in those samples. Concentrations in subsequent samples from the two wells (MV-7, in 1992 and 1995; and MV-61, in 1990 and 1993) were less than the MRL. The later results 
indicate that the initial results for these two samples were not reliable.

At three sampling sites, replicate pairs also were collected for analyses by the ISU laboratory for strontium-90 (table 6). The Z-values indicated that results of 1 replicate pair were not equivalent and 2 pairs, or 67 percent of the results, were equivalent.

Tritium. Fifteen replicate pairs of samples were analyzed for tritium by the NWQL; however, one sample of one replicate pair was lost before analysis (table 6 ). The $Z$-values indicated that results of 3 replicate pairs were not equivalent and 11 pairs, or 79 percent of the results, were equivalent. The reason for the lack of equivalence of the results is unknown.

\begin{tabular}{|c|c|c|c|c|}
\hline \multirow{2}{*}{$\begin{array}{c}\text { Site } \\
\text { identifier }\end{array}$} & \multirow{2}{*}{$\begin{array}{c}\text { Date } \\
\text { sampled }\end{array}$} & \multicolumn{2}{|c|}{ NWQL } & \multirow{2}{*}{ ISU $^{1}$} \\
\hline & & $\operatorname{Lab}^{2}$ & Lab $B^{3}$ & \\
\hline $\mathrm{MV}-27(28)$ & $8 / 15 / 89$ & $x$ & & . \\
\hline $\mathrm{MV}-7(8)$ & $8 / 16 / 89$ & $x$ & & \\
\hline MV-33(34) & $8 / 17 / 89$ & $\mathrm{x}$ & & \\
\hline$M V-43(44)$ & $8 / 22 / 89$ & $\mathrm{x}$ & & \\
\hline $\mathrm{MV}-61(60)$ & $9 / 14 / 89$ & $\mathrm{x}$ & & \\
\hline $\mathrm{MV}-4$ (8) & $8 / 13 / 90$ & & $\mathrm{x}$ & \\
\hline MV-24(28) & $8 / 12 / 91$ & & $x$ & $x$ \\
\hline $\mathrm{MV}-40(34)$ & $8 / 15 / 91$ & & $\mathrm{x}$ & $\mathrm{x}$ \\
\hline$M V-46(44)$ & $6 / 23 / 92$ & & $x$ & $x$ \\
\hline MV-36(60) & $7 / 29 / 92$ & & $x$ & $x$ \\
\hline$M V-21(8)$ & $8 / 04 / 93$ & & & $x$ \\
\hline MV-10(28) & $8 / 11 / 94$ & & & $\mathrm{x}$ \\
\hline MV-56(34) & $8 / 09 / 94$ & & & $x$ \\
\hline MV-38(44) & $7 / 24 / 95$ & & & $x$ \\
\hline MV-55(60) & $7 / 26 / 95$ & & & $\mathrm{x}$ \\
\hline
\end{tabular}

${ }^{1}$ Analytical results were reported as cesium-137 and in 1993 only, both as cesium- 137 and as cobalt- 60 .

${ }^{2}$ Analytical results were reported as potassium-40, cobalt60 , lead-212, bismuth-212, radium-224, radium-226, radium-228, and thorium-234.

${ }^{3}$ Analytical results were reported as potassium-40, cesium137, lead-212, lead-214, bismuth-212, bismuth-214, radium-226, uranium-235, and uranium-238.
At 13 sampling sites, replicate pairs also were collected for analyses by the ISU laboratory for tritium (table 6). The Z-values indicated that results of 1 replicate pair were not equivalent and 12 pairs, or 92 percent of the results, were equivalent.

Gamma radiation. Ten replicate pairs of samples were analyzed for gamma radiation by the NWQL (table 7). Two laboratories had been contracted to perform the analyses, one in 1989 , and one in 1990-92. Nine replicate pairs were analyzed for gamma radiation by the ISU laboratory from 1991-95. During 1991-93, the NWQL contract laboratory and the ISU laboratory were performing gamma-radiation analyses on separate replicate pairs collected at the same sites, at the same times, but were not always using the same methods nor reporting the same isotopes. See table to the left for a summary.

The NWQL analytical data were difficult to interpret and few statistical comparisons could be made between the results of the replicate pairs. Results for some isotopes were not reported, which indicated that the isotopes were not detected (Mullin, 1997, written commun.), in either the water-quality sample or the QA replicate sample, or both. Neither bismuth212 nor bismuth-214 was detected in replicate samples. When no isotopes were detected in either sample of the replicate pair, the results were considered equivalent. When an isotope was detected in one sample of a replicate pair larger than twice the uncertainty and not detected in the other, the results were considered not equivalent. When an isotope was detected in both samples of a replicate pair, the results were compared statistically using equation 1 . There were 43 replicate pairs that had either no results or a result for only one sample of the pair; 28 were considered equivalent and 15 , not equivalent. The statistical comparisons were done on only the 14 replicate pairs that had a result reported for each sample of the pair; the Z-values indicated that results for 5 
replicate pairs were not equivalent and 9 pairs were equivalent. In all, 57 replicate pairs were analyzed for gamma radiation by the NWQL; results of 20 of the replicate pairs were not equivalent and 37 pairs, or 65 percent of the results, were equivalent.

During 1991-95, water-quality samples and QA replicate samples also were analyzed by the ISU for gamma radiation and were reported as cesium-137 and, in 1993 only, both as cesium-137 and as cobalt- 60 . Results were reported for both samples of all the replicate pairs (table 7). The Z-values indicated that results of 1 replicate pair were not equivalent and 8 pairs, or 89 percent of the results, were equivalent.

\section{Organic Constituents}

Dissolved organic carbon. Eleven replicate pairs of samples were analyzed by the NWQL for DOC (table 8). The precision data for the DOC method (Wershaw and others, 1987, p. 15) were used to determine a linear regression equation for calculating the standard deviations at low concentrations. The Z-values indicated that results of 1 replicate pair were not equivalent and 10 pairs, or 91 percent of the results, were equivalent.

Anionic surfactants as methylene blue active substances. Fifteen replicate pairs of samples were analyzed by the NWQL for whole water recoverable ${ }^{l}$ (WWR) MBAS (table 8). Because this analysis was not included in the BSP the standard deviations were calculated using the RSD of 10 percent reported in the NWQL catalog (Pritt and Jones, 1989, p. 5-45). Because of the way the data were rounded, and because the RSD of 10 percent is very small, analytical results at or near the MRL were not equivalent unless they were numerically the same. The $Z$-values indicated that results of 2 replicate pairs were not equivalent and 13 pairs, or 87 percent of the results, were equivalent.
Volatile organic compounds. Fifteen replicate pairs of samples were analyzed by the NWQL for 36-65 VOC's. The number of VOC's analyzed for each year differed; the VOC's and years analyzed are presented in table 22. Concentrations of eight of the VOC's were at or greater than the MRL. Because neither an MPD nor a standard deviation was available for these eight VOC's, the standard deviations were calculated from the RSD's provided by Rose and Schroeder (1995). The following is a list of these compounds and the RSD's used to determine the standard deviations for the statistical comparisons: benzene, 9.3 percent; ethylbenzene, 13 percent; $n$-propylbenzene, 11 percent; $1,1,1$-trichloroethane, 12 percent; 1,2,4-trimethylbenzene, 14 percent; 1,3,5-trimethylbenzene, 13 percent; toluene, 11 percent; and xylene, 11 percent.

The results of the statistical comparisons of the replicate pairs analyzed for the compounds with concentrations at or above the MRL's are shown in table 9. All the results for replicate pairs were equivalent, except results of analyses for 1,3,5-trimethylbenzene and xylene for one replicate pair [MV-33(34)]. All the results of the replicate pairs that were less than the MRL's were considered equivalent; therefore,

\footnotetext{
${ }^{l}$ Whole water, recoverable pertains to the constituents in solution after an unfiltered representative water-suspended-sediment sample is digested (usually using a dilute acid solution). Complete dissolution of the particulate matter often is not achieved by the digestion treatment, and thus the determination represents something less than the "total" amount (that is, less than 95 percent) of the constituent present in the dissolved and suspended phases of the sample. For inorganic determinations, digestions are performed in the original sample container to ensure digestion of material absorbed on the container walls. To achieve comparability of analytical data, equivalent digestion procedures would be required of all laboratories performing such analyses because different digestion procedures are likely to produce different analytical results (Timme, 1995, p. 95).
} 
more than 99 percent of the results were equivalent.

Pesticides and gross polychlorinated compounds. During 1989-95, 15 replicate pairs of samples were analyzed by the NWQL for 92 different pesticides and gross PCB's and PCN's. The number of pesticides analyzed for each year differed; the pesticides, gross polychlorinated compounds, and years analyzed are presented in table 23. Almost all of the analytical results were less than the MRL. Results for analyses for desethylatrazine and DDT in two replicate pairs, MV-38(44) and MV-43(44) were equivalent but greater than the MRL (table 10). Results of analyses for both atrazine and desethylatrazine for two replicate pairs, MV-10(28) and MV-43(44) were uncensored below the MRL, but were reported with an " $E$ " code to qualify the result, and caution the user that the result is estimated (Zaugg and others, 1995, p. 21, 35). These results, therefore, were considered indeterminate. The results of four replicate pairs were indeterminate and 892 pairs, or more than 99 percent of the results, were equivalent.

\section{Stable isotopes}

Five replicate pairs of samples were analyzed by the NWQL for the stable-isotopes: $\delta^{2} \mathrm{H}, \delta^{18} \mathrm{O}, \delta^{13} \mathrm{C}, \delta^{34} \mathrm{~S}$, and $\delta^{15} \mathrm{~N}$ (table 12 ). The $Z$-values were calculated using the analytical results and the precision estimates listed in NWQL Services Catalog (Timme, 1994, p. 69-70).

All of the results of the replicate pairs analyzed for stable isotopes were equivalent except results for $\delta^{13} \mathrm{C}$ in one pair and $\delta^{15} \mathrm{~N}$ in two pairs (table 12). The reason for the lack of equivalence of the three replicate pairs is unknown. The $Z$-values indicated that the results for 3 replicate pairs were not equivalent and 22 pairs, or 88 percent of the results, were equivalent.

\section{QUALITY-ASSURANCE/QUALITY- CONTROL SAMPLES, BLANKS}

Blanks were prepared using bottled, distilled water from a grocery store; distilled, deionized water from the Radiological and Environmental Sciences Laboratory (RESL); inorganic blank water (IBW) and volatile organic compound blank water (VBW) from the NWQL; and distilled water from the IDWR. Source-solution blanks were identified as MV-22. Five equipment blanks were prepared and identified as QA-MV, MV-62, MV-62(A), MV-62(B), and MV-62(C).

Sources and descriptions of the source-solution and equipment blanks that were analyzed by both the NWQL and IDHWL are presented in table 2; and analytical results are presented in tables 13 through 20.

Although some constituents of interest may be detected, blank samples should not have measurable concentrations of those constituents. Measurable concentrations are those that exceed the MRL plus twice the MPD or standard deviation. The radiochemical concentrations of blanks should not exceed 2SPE or two standard deviations.

\section{Source-solution blanks}

A source solution is water that is free of the constituents of interest and is used as a stock solution for other blanks. This type of blank is used to determine if the source solution is free of contaminants. Source-solution blanks also are used to determine the variability of methods or analysts at a laboratory, and whether the laboratory has introduced a bias into the analytical process. Three source-solution blanks, prepared in 1989, 1990, 1993, respectively, were analyzed by the NWQL for inorganic, radioactive, and organic constituents. The 1989 source-solution blank also was analyzed by the ISU laboratory for tritium. 
Table 2. Identification, source, and description of source-solution and equipment blanks

[ldentifier: see section on Quality Assurance/Quality Control Samples, Blank Samples for explanation. Abbreviations: IBW, inorganicfree blank water; VBW, volatile organic compound blank water.]

\begin{tabular}{|c|c|c|c|}
\hline Identifier & $\begin{array}{c}\text { Date } \\
\text { prepared }\end{array}$ & Source & Description \\
\hline \multicolumn{4}{|c|}{ Source-solution blanks } \\
\hline MV-22 & $8 / 19 / 89$ & Grocery store & Bottled, distilled water \\
\hline MV-22 & $11 / 02 / 90$ & Radiological and Environmental Sciences Laboratory & Distilled, deionized water \\
\hline MV-22 & $8 / 11 / 93$ & USGS National Water Quality Laboratory & IBW and VBW ${ }^{1}$ \\
\hline \multicolumn{4}{|c|}{ Equipment blanks } \\
\hline QA-MV & $12 / 14 / 89$ & Idaho Department of Water Resources & Distilled water rinsate of garden hose \\
\hline $\mathrm{MV}-(62)$ & $8 / 15 / 91$ & Idaho Department of Water Resources & $\begin{array}{l}\text { Distilled water rinsate of portable } \\
\text { sampling port }\end{array}$ \\
\hline$M V-62(A)$ & $6 / 24 / 92$ & Idaho Department of Water Resources & $\begin{array}{l}\text { Distilled water rinsate of portable } \\
\text { sampling port }\end{array}$ \\
\hline$M V-62(B)$ & $7 / 30 / 92$ & Idaho Department of Water Resources & $\begin{array}{l}\text { Distilled water rinsate of portable } \\
\text { sampling port }\end{array}$ \\
\hline $\mathrm{MV}-62(\mathrm{C})$ & $11 / 12 / 92$ & USGS National Water Quality Laboratory & $\begin{array}{l}\text { VBW rinsate of peristaltic pump and } \\
\text { filtering apparatus }\end{array}$ \\
\hline
\end{tabular}

${ }^{1}$ The source-solution blank was prepared using two source solutions.

The 1990 and 1993 source-solution blanks were analyzed for major ions. Although calcium and magnesium were detected in both blanks, and chloride in the 1990 blank, the analytical results were within two MPD's, which indicated that the blanks had no measurable concentrations of major ions. However, a measurable concentration of silica was found in the 1990 blank (table 13).

All three source-solution blanks were analyzed for dissolved nutrients; no measurable concentrations were found (table 14). The source-solution blanks also were analyzed for dissolved cyanide, DOC, and WWR MBAS. Only the 1990 blank was analyzed for dissolved cyanide; the result was less than the MRL. The 1990 and 1993 blanks were analyzed for DOC; the 1990 blank had a measurable concentration of DOC. All three blanks were analyzed for WWR MBAS; the 1989 blank had a measurable concentration of WWR MBAS (table 14).

All source-solution blanks were analyzed for the following dissolved trace elements: arsenic, barium, cadmium, chromium, lead, mercury, selenium, and silver. The 1990 blank also was analyzed for dissolved iron and hexavalent and total chromium. The 1993 blank was analyzed for the following additional dissolved trace elements: aluminum, beryllium, cobalt, copper, lithium, manganese, molybdenum, nickel, strontium, vanadium, and zinc. None of the source-solution blanks had measurable concentrations of trace elements (table 15).

The source-solution blanks were analyzed for gross radioactivity, radon-222, strontium90 , tritium, uranium, radium-224, radium-226, radium-228, and gamma radiation (table 17 ). Analyses for gross radioactivity included both 
the dissolved and suspended fractions in the 1989 and 1990 blanks, but only the dissolved fractions in the 1993 blank. Blanks were analyzed for gross alpha radioactivity as uranium and as thorium-230 and for gross beta radioactivity as cesium-137 and as strontium-90/ yttrium-90. The only measurable concentration of gross radioactivity in any blank was dissolved gross alpha radioactivity both as uranium and as thorium-230 in the 1989 blank. All three blanks were analyzed for strontium90 and tritium. The 1989 blank also was analyzed for tritium by the ISU laboratory. The 1990 and 1993 blanks had measurable concentrations of both strontium-90 and tritium. The large concentration of tritium in the 1990 blank was due to tritium in the water supply at the Central Facilities Area at the INEEL, where the RESL is located (Mann and Cecil, 1990). The 1989 and 1990 blanks were analyzed for radon-222, uranium, radium-226, and radium-228. Concentrations of radon-222 were detected in the 1990 blank sample; concentrations of radium-226 were detected in both samples; concentrations of radium-228 in 1990. Analyses of the 1989 and 1990 blanks for gamma radiation showed that the 1989 equipment blank had measurable concentrations of cobalt- 60 , potassium- 40 , radium224 , and radium-226 (table 18).

For the VOC's, concentrations of only two VOC's, chloroform and methylene chloride, were at, or exceeded, the MRL's (table 19). Measurable concentrations of chloroform were detected in the 1989 blank, and concentrations of methylene chloride were detected in the 1993 blank.

The bottled, distilled water from the grocery store and the distilled, deionized water from the RESL had measurable concentrations of the many constituents of interest and, therefore, were unsuitable for use as a source-solution blank. Use of these water sources as blanks has been discontinued.

\section{Equipment Blanks}

Equipment blanks were prepared using distilled water from the IDWR and VBW from the NWQL. Equipment blanks were passed through and collected from different sampling apparatus in the same manner as the waterquality samples. Then, the blanks were analyzed for the constituents of interest to determine if the sample-collection process or equipment-cleaning process had introduced a bias to the analytical results. The following five equipment blanks were prepared: QA-MV in 1989, MV-62 in 1991, and MV-62(A), (B), and $(C)$ in 1992.

During the first round of sampling, in 1989, a new garden hose was used to divert water away from pumps and associated electrical equipment (Wegner and Campbell, 1991, p. 37). Several sites that had concentrations of VOC's that exceeded the MRL were resampled and an equipment blank (QA-MV) was prepared to determine whether the contamination was from the water in the wells or from the garden hose. The analytical results showed that there were no measurable concentrations of VOC's in the resampled water, but there were measurable concentrations in the equipment blank, which indicated that the garden hose had been the source of the contamination (table 20). Since then, a portable, stainlesssteel sampling port has been used to collect the samples.

In 1991, one equipment blank (MV-62) was prepared by passing distilled water through the stainless-steel sampling port. The rinsate then was analyzed by the IDHWL for the following dissolved trace elements: arsenic, barium, beryllium, cadmium, chromium, lead, mercury, selenium, silver; and for VOC's (tables 16 and 19). No measurable concentrations of those constituents were detected, except for chloroform, which was not 
present in any of the water-quality or QA replicate samples.

In 1992, two other equipment blanks, $\mathrm{MV}-62(\mathrm{~A})$ and (B), were prepared in the same manner as MV- 62 and analyzed by $\mathrm{DHWL}$ for the same dissolved trace elements, and these additional trace elements: aluminum, cobalt, copper, iron, lithium, manganese, molybdenum, nickel, strontium, vanadium, and zinc; and for VOC's (tables 16 and 19). The blanks had no measurable concentrations of any of the trace elements or VOC's.

Several water-quality samples contained DOC; therefore, another equipment blank, MV-62(C) was prepared in 1992 by passing VBW through the peristaltic pump tubing and the silver filter apparatus used to collect and filter the samples analyzed for DOC. The rinsate then was analyzed for DOC; there was no measurable concentration of DOC in the sample, which demonstrated that the DOC was not an artifact of the sampling process.

\section{SUMMARY AND CONCLUSIONS}

The public is concerned about the wastedisposal practices at the INEEL and the effects these practices may have on the water quality of the Snake River Plain aquifer. To monitor these effects, the USGS collected several water samples from 55 sites in the area between the southern boundary of the INEEL and Hagerman, Idaho, from 1989 through 1995. The NWQL, the IDHWL, and the ISU analyzed these water-quality samples for inorganic constituents, gross radioactivity and radionuclides, organic constituents, and stable isotopes. Concurrently, replicate samples collected and blank samples prepared for the QA/QC program were analyzed; results of the analyses of replicate pairs of samples were compared statistically for equivalence on the basis of the precision associated with each result. Determinations as to whether replicate pairs are equivalent, along with the BTD\&QS report concerning the NWQL, and historical data, are useful in assessing sources of imprecision, bias, and, in some cases, inaccuracy.

Within the major ion analyses, 99 percent were equivalent; nutrients and cyanide, 92 percent; trace elements, 98 percent; gross radioactivity and radionuclides, 81 percent; organic constituents, more than 99 percent; and stable isotopes, 88 percent. Statistical comparisons of all the data indicated that 95 percent of the replicate pairs were equivalent. The large percentage of analytical results of replicate pairs that were equivalent indicates that the samples were collected in a manner that ensured the quality of the data.

Ninety percent or more of the analytical results for each constituent were equivalent except results for orthophosphate, 67 percent; aluminum, 70 percent; vanadium, 89 percent; zinc, 89 percent; gross alpha radioactivity, 80 percent; gross beta radioactivity, 88 percent; radon-222; 70 percent; radium-226, 80 percent; strontium-90, 87 percent; tritium, 79 percent; gamma radiation, 65 percent; MBAS, 87 percent; $\delta^{13} \mathrm{C}, 80$ percent; and $\delta^{15} \mathrm{~N}, 60$ percent.

Although orthophosphate analyses were included in the BSP, the concentrations were higher than those of the replicate pairs in this report; therefore, the statistical comparisons of the replicate pairs analyzed for orthophosphate that were less than $0.03 \mathrm{mg} / \mathrm{L}$ were indeterminate.

The BTD\&QS, in the BSP, has documented a lack of precision in the analytical method to determine concentrations of aluminum. The information from the QADATA program that is available through the USGS computer network shows that the aluminum analyses of the BSP samples have displayed high variability; therefore, the BTD\&QS has reset the control limits to three standard deviations. The MPD's used in the statistical com- 
parisons were multiplied by 1.5 to adjust for the higher control limits.

Although only 89 percent of the replicate pairs analyzed for vanadium were equivalent, lack of precision was not necessarily indicated. Of the nine replicate pairs analyzed, all were equivalent except for results of one replicate pair [MV-24(28)], which were at the MRL and less than the MRL. The MPD's of these results were relatively small and equivalency could not be determined.

Nine replicate pairs were analyzed for zinc; results of one replicate pair [MV-36(60)] were not equivalent. The results were $<3 \mu \mathrm{g} / \mathrm{L}$ for the water quality samples and $30 \mu \mathrm{g} / \mathrm{L}$ for the QA replicate. The reason for the large difference between results of each sample of the replicate pair could not be determined. A more recent analytical value for dissolved zinc at the same site and the results of a replicate pair collected sequentially and analyzed by another laboratory, were near the MRL. These lower values indicated that the result for the waterquality sample was accurate and the result for the QA replicate sample was inaccurate.

Only 80 percent of the replicate pairs analyzed for gross alpha radioactivity were equivalent. Most results that were not equivalent were from samples collected and analyzed in 1989. Although the laboratory that analyzed the samples in 1989 used smaller precision estimates than the analyzing laboratories during 1990-95, close scrutiny of the data shows that use of larger precision estimates would not result in a significant increase in the number of equivalent replicate pairs. It is unlikely that the lack of precision was due to inadequate field methods because the same field methods used in 1989 were used during 1990-93 and all the replicate pairs were equivalent during that time period.

Only 88 percent of the replicate pairs analyzed for gross beta radioactivity were equiva- lent. Although the same laboratories that analyzed samples for the gross alpha radioactivity analyzed samples for gross beta radioactivity, it cannot be assumed that the lack of precision was due to laboratory conditions in 1989 because there were also non equivalent replicate pairs in 1992 and 1993.

Because radon-222 is a gas, it readily migrates in the presence of moving water. In general, radon-222 data are hard to interpret because of the short half-life of the radionuclide and the complex nature of the factors affecting its concentrations (Durrance, 1986, p. 219).

Concentrations of strontium-90 in one sample of each of the two nonequivalent replicate pairs analyzed by the NWQL in 1989 were larger than three times the analytical uncertainty. It is unlikely that strontium-90 was in those samples. Concentrations in subsequent samples from the two wells (MV-7, in 1992 and 1995; and MV-61, in 1990 and 1993) were less than the MRL, indicating that the initial laboratory analyses of these two samples are not reliable.

Results of several replicate pairs that were analyzed for tritium were not equivalent; the reason for the lack of equivalence is unknown.

The NWQL analytical data for gamma radiation were difficult to interpret and few statistical comparisons could be made between the results of the replicate pairs. Analytical results and uncertainties were reported for only 14 of the 57 replicate pairs. When no isotopes were detected in either sample of the replicate pair, the results were considered equivalent. Whenever an isotope was detected in one sample of a replicate pair larger than twice the uncertainty and not detected in the other, the results were considered not equivalent.

The analysis for WWR MBAS was not included in the BSP; therefore, the compari- 
sons of the results of the replicate pairs and the standard deviations were calculated using the RSD of 10 percent reported in the NWQL catalog. Because of the way the data were rounded and because the RSD of 10 percent is very small, analytical results at or near the MRL were not equivalent unless they were numerically the same.

Results of analyses for stable isotopes in several replicate pairs were not equivalent. The reason for the lack of equivalence is unknown.

Blanks are an important component of the QA/QC program. Source solutions that were used for preparation of blanks were: bottled, distilled water from a grocery store; distilled, deionized water from the RESL; IBW and VBW from the NWQL; and distilled water from the IDWR. Analytical results of sourcesolution blanks can be used to determine variability or bias at the laboratory and whether the blank solution is free of contaminants. An equipment blank that has been passed through and collected from all or part of the sampling apparatus can be used to detect bias introduced through use of that equipment. Blanks should not have measurable concentrations of the constituents of interest. Measurable concentrations are those that exceed the MRL plus twice the MPD or standard deviation. Radiochemical concentrations in blanks should not exceed 2SPE or two standard deviations.

Three source-solution blanks, all identified as MV-22, were prepared, one in each of the following years: 1989, 1990, and 1993. They were analyzed by the NWQL for major ions, nutrients, dissolved cyanide, DOC, MBAS, trace elements, gross radioactivity and radionuclides, and VOC's, although not all analyses were performed each year. The following constituents were present in source-solution blanks: silica (1990), DOC (1990), MBAS (1989), gross alpha radioactivity (1989), strontium-90 (1990, 1993), tritium (1990, 1993), radon-222 (1990), radium-226 (1989, 1990) radium-228 (1990), gamma radiation (1989), chloroform (1989), and methylene chloride (1993). The bottled, distilled water from the grocery store (1989) and the distilled, deionized water from the RESL (1990) had measurable concentrations of many of the constituents of interest and were unsuitable for use as source-solution blanks. Use of these water sources as blanks has been discontinued.

Three equipment blanks were prepared during sample collection: MV-62 in 1991 and MV-62(A) and (B) in 1992. Two other equipment blanks were prepared after the samples were collected and the analyses completed; QA-MV in 1989 and MV-62(C) in 1992. All were analyzed by the IDHWL for trace elements and VOC's except QA-MV and MV62(C), which were analyzed by the NWQL for VOC's and DOC, respectively. With the exception of VOC's in QA-MV and chloroform in MV-62, no measurable concentrations of these constituents were present in the equipment blanks. When comparing the results of analyses performed by the IDWHL and the NWQL, it must be remembered that the IDHWL method detection limits were greater than those of the NWQL.

During the first round of sampling, in 1989 , a new garden hose was used to divert water away from pumps and associated electrical equipment. Several sites that had concentrations of VOC's greater than the MRL were resampled and an equipment blank (QA-MV) was prepared to determine whether the contamination was from the water in the wells or from the garden hose. The analytical results showed that there were no measurable concentrations of VOC's in the resampled water, but there were in the equipment blank, which indicated that the garden hose had been the source of the contamination. Since then, a portable, stainless-steel sampling port has been used to collect the samples. 
Another equipment blank, MV-62(C), was prepared after the samples were collected and the analyses were completed in 1992 because several samples had contained DOC. The equipment blank of the filtering apparatus was prepared to determine whether the DOC had been introduced during the sampling process. The result of the analysis showed that no measurable concentration of DOC was present.

Evaluation of the QA/QC data, the information from the BSP, and historical data help to assess precision and bias of field methods at the INEEL Project Office. The large percentage of results of replicate pairs of samples that were equivalent and blanks that were free of the constituents of interest validates the methods and procedures and supports the reliability of the data. The QA/QC data also are useful in determining the source of inconsistencies when results of replicate pairs are not equivalent or when blanks contain measurable concentrations of constituents of interest. For example, when results of a specific analysis for several replicate pairs are not equivalent, and the results for other analyses of those pairs are equivalent, the source of the inconsistencies may be the laboratory procedures. On the other hand, when results of all the analyses of a replicate pair are not equivalent, the source of the inconsistencies may be the field procedures. In general, replicate samples do not address accuracy; but, a large $Z$-value, when the results of two replicate samples are compared statistically for equivalence, indicates that at least one of the results is inaccurate.

\section{REFERENCES CITED}

Bartholomay, R.C., Edwards, D.D., and Campbell, L.J., 1992, Radionuclides, inorganic constituents, organic compounds, and bacteria in water from selected wells and springs from the southern boundary of the Idaho National Engineering Laboratory to the Hagerman area, Idaho, 1990: U.S. Geological Survey OpenFile Report 92-91 (DOE/ID 22102), 42 p.
----1993, Radionuclides, inorganic constituents, organic compounds, and bacteria in water from selected wells and springs from the southern boundary of the Idaho National Engineering Laboratory to the Hagerman area, Idaho, 1991: U.S. Geological Survey Open-File Report 93-102 (DOE/TD-22108), $42 \mathrm{p}$.

----1994a, Radionuclides, inorganic constituents, organic compounds, and bacteria in water from selected wells and springs from the southern boundary of the Idaho National Engineering Laboratory to the Hagerman area, Idaho, 1992: U.S. Geological Survey Open-File Report 94-76 (DOE/ID-22114), 41 p.

-1994b, Radionuclides, stable isotopes, inorganic constituents, and organic compounds in water from selected wells and springs from the southern boundary of the Idaho National Engineering Laboratory to the Hagerman area, Idaho, 1993: U.S. Geological Survey OpenFile Report 94-503 (DOE/ID-22117), 35 p.

Bartholomay, R.C., Williams, L. M., and Campbell, L.J., 1995, Radionuclides, inorganic constituents, and organic compounds in water from selected wells and springs from the southern boundary of the Idaho National Engineering Laboratory to the Hagerman area, Idaho, 1994: U.S. Geological Survey OpenFile Report 95-718 (DOE/ID-22124), 37 p.

---1996, Radionuclides, inorganic constituents, and organic compounds in water from selected wells and springs from the southern boundary of the Idaho National Engineering Laboratory to the Hagerman area, Idaho, 1995: U.S. Geological Survey Open-File Report 96-496 (DOE/ID-22130), 29 p.

Claassen, H.C., 1982, Guidelines and techniques for obtaining water samples that accurately represent the water chemistry of an aquifer: U.S. Geological Survey Open-File Report 82$1024,49 \mathrm{p}$.

Durrance, E.M., 1986, Radioactivity in geology, principles and applications, John Wiley and Sons, Inc., New York, N.Y., 441 p. 
Erdmann, D.E., and Thomas, J.D., 1985, Quality assurance of U.S. Geological Survey waterquality field measurements in Taylor, J.K., and Stanley, T.W., eds., Quality assurance for environmental measurements: Philadelphia, American Society for Testing and Materials, ASTM STP 867, $441 \mathrm{p}$.

Faires, L.M., 1992, Methods of analysis by the U.S. Geological Survey National Water Quality Laboratory-determinations of metals in water by inductively coupled plasma-mass spectrometry: U.S. Geological Survey OpenFile Report 92-634, 28 p.

Fishman, M.J., ed., 1993, Methods of analysis by the U.S. Geological Survey National Water Quality Laboratory - determination of inorganic and organic constituents in water and fluvial sediments: U.S. Geological Survey Open-File Report 93-125, 217 p.

Fishman, M.J., and Friedman, L.C., eds., 1989, Methods for determination of inorganic substances in water and fluvial sediments: U.S. Geological Survey Techniques of WaterResources Investigations, book 5, chap. A1, $545 \mathrm{p}$.

Friedman, L.C., and Erdmann, D.E., 1982, Quality assurance practices for the chemical and biological analyses of water and fluvial sediments: U.S. Geological Survey Techniques of Water-Resources Investigations, book 5 , chap. A6, $181 \mathrm{p}$.

Goerlitz, D.F., and Brown, Eugene, 1972, Methods for analysis of organic substances in water: U.S. Geological Survey Techniques of WaterResources Investigations, book 5, chap. A3, $40 \mathrm{p}$.

Horowitz, A.J., Demas, C.R., Fitzgerald, K.K., Miller, T.L., and Rickert, D.A., 1995, U.S. Geological Survey protocol for the collection and processing of surface-water samples for the subsequent determination of inorganic constituents in filtered water: U.S. Geological Survey Open-File Report 94-539, $57 \mathrm{p}$.
Long, H.K., and Farrar, J.W., 1993, Report of the U.S. Geological Survey's evaluation program for standard reference samples distributed in April 1993 T-123 (trace constituents), T-125 (trace constituents), M-126 (major constituents), N-38 (nutrients), N-39 (nutrients), P-20 (low ionic strength), and $\mathrm{Hg}-16$ (mercury): U.S. Geological Survey Open-File Report 93-436, $149 \mathrm{p}$.

Lucey, K.J., 1990, QADATA user's manual: an interactive computer program for the retrieval and analysis of the results from the external blind sample quality-assurance project of the U.S. Geological Survey: U.S. Geological Survey Open-File Report 90-162, 53 p.

Maloney, T.J., Lutke, A.S., and Krizman, T.L., 1993, Quality assurance for routine water analysis in the laboratories of the U.S. Geological Survey for water year 1990: U.S. Geological Survey Water-Resources Investigations Report 93-4082, $145 \mathrm{p}$.

Mann, L.J., 1996, Quality-assurance plan and field methods for quality-of-water activities, U.S. Geological Survey, Idaho National Engineering Laboratory, Idaho: U.S. Geological Survey Open-File Report 96-615 (DOE/ID-22132), 37 p.

Mann, L.J., and Cecil, L.D., 1990, Tritium in ground water at the Idaho National Engineering Laboratory, Idaho: U.S. Geological Survey Water-Resources Investigations Report 904090 (DOE/ID-22090), 35 p.

Mann, L.J., and Knobel, L.L., 1990, Radionuclides, metals, and organic compounds in water, eastern part of A\&B Irrigation District, Minidoka County, Idaho: U.S. Geological Survey Open-File Report 90-191 (DOE/ID22087), $36 \mathrm{p}$.

Ott, R.L., 1993, An introduction to statistical methods and data analysis (4th ed.): Belmont, Calif., Wadsworth Publishing Company, $1183 \mathrm{p}$. 
Pritt, J., and Jones, B.E., eds., 1989, 1990 National Water Quality Laboratory services catalog: U.S. Geological Survey Open-File Report 89-386 [variously paged].

Pritt, J.W. and Raese, J.W., eds., 1992, Quality assurance/quality control manual, National Water Quality Laboratory: U.S. Geological Survey Open-File Report 92-495, 33 p.

-----1995, Quality assurance/quality control manual, National Water Quality Laboratory: U.S. Geological Survey Open-File Report 95-443, $35 \mathrm{p}$.

Rose, D.L., and Schroeder, M.P., 1995, Methods of analysis by the U.S. Geological Survey National Water Quality Laboratory-determination of volatile organic compounds in water by purge and trap capillary gas chromatograph/mass spectrometry: U.S. Geological Survey Open-File Report 94-708, 26 p.

Stevens, H.H., Jr., Ficke, J.F., and Smoot, G.F., 1975, Water temperature - influential factors, field measurement, and data presentation: U.S. Geological Survey Techniques of WaterResources Investigations, book 5, chap. D1, $65 \mathrm{p}$.

Thatcher, L.L., Janzer, V.J., and Edwards, K.W., 1977, Methods for determination of radioactive substances in water and fluvial sediments: U.S. Geological Survey Techniques of WaterResources Investigations, book 5, chap. A5, $95 \mathrm{p}$.

Timme, P.J., 1994, 1994 National Water Quality Laboratory services catalog: U.S. Geological Survey Open-File Report 94-304 [variously paged].
1995, 1995 National Water Quality Laboratory services catalog: U.S. Geological Survey Open-File Report 95-352 [variously paged].

Volk, William, 1969, Applied statistics for engineers ( $2 \mathrm{~d}$ ed.): New York, McGraw-Hill Book Company, $415 \mathrm{p}$.

Wegner, S.J., and Campbell, L.J., 1991, Radionuclides, chemical constituents, and organic compounds in water from designated wells and springs from the southern boundary of the Idaho National Engineering Laboratory to the Hagerman area, Idaho, 1989: U.S. Geological Survey Open-File Report 91-232 (DOE/ID22098), 49 p.

Wershaw, R.L., Fishman, M.J., Grabbe, R.R., and Lowe, L.L, eds., 1987, Methods for the determination of organic substances in water and fluvial sediments: U.S. Geological Survey Techniques of Water-Resources Investigations, book 5, chap. A3, 80 p.

Wood, W.W., 1981, Guidelines for collection and field analysis of ground-water samples for selected unstable constituents: U.S. Geological Survey Techniques of Water-Resources Investigations, book 1, chap. D2, $24 \mathrm{p}$.

Zaugg, S.D., Sandstrom, M.W., Smith, S.G., Fehlberg, K.M., 1995, Methods of analysis by the U.S. Geological Survey National Water Quality Laboratory - determination of pesticides in water by $\mathrm{C}-18$ solid-phase extraction and capillary-column gas chromatograph/mass spectrometry with selected-ion monitoring: U.S. Geological Survey Open-File Report 95-181, $49 \mathrm{p}$. 
SUPPLEMENTAL INFORMATION 
Table 3. Results of replicate pairs of samples from selected wells and springs, eastern Snake River Plain, analyzed for major ions

[Analyses performed by the U.S. Geological Survey National Water Quality Laboratory (NWQL) and the Idaho Department of Health and Welfare Laboratory (IDHWL). Site identifier: water-quality sample identifier followed by quality-assurance replicate sample identifier in parentheses; see figure 2 for location of sites. Z-value: see section on statistical comparisons for explanation. Remark: no entry, analytical results of replicate pairs are statistically equivalent; $N$, the analytical results are not statistically equivalent. Abbreviations: $\mathrm{mg} / \mathrm{L}$, milligram per liter; MV, water-quality sample; QA, quality assurance replicate sample; na, not analyzed]

\begin{tabular}{|c|c|c|c|c|c|c|c|}
\hline \multirow{2}{*}{$\begin{array}{c}\text { Site } \\
\text { identifier }\end{array}$} & \multirow{2}{*}{$\begin{array}{c}\text { Date } \\
\text { sampled }\end{array}$} & \multicolumn{2}{|c|}{$\begin{array}{c}\text { Dissolved concentration, } \\
\text { NWQL } \\
(\mathrm{mg} / \mathrm{L})\end{array}$} & \multirow[b]{2}{*}{ Z-value } & \multirow[b]{2}{*}{ Remark } & \multicolumn{2}{|c|}{$\begin{array}{c}\text { Total concentration, } \\
\text { DHWL } \\
(\mathrm{mg} / \mathrm{L})\end{array}$} \\
\hline & & $\mathbf{M V}$ & QA & & & MV & QA \\
\hline \multicolumn{8}{|c|}{ Calcium } \\
\hline$M V-4(8)$ & $8 / 13 / 90$ & 50 & 47 & 0.90 & & & \\
\hline $\mathrm{MV}-24(28)$ & $8 / 12 / 91$ & 73 & 74 & .21 & & & \\
\hline $\mathrm{MV}-40(34)$ & $8 / 15 / 91$ & 31 & 31 & .00 & & & \\
\hline $\mathrm{MV}-46(44)$ & $6 / 23 / 92$ & 27 & 28 & .50 & & 27 & 27 \\
\hline MV-36(60) & $7 / 29 / 92$ & 51 & 51 & .00 & & 54 & 54 \\
\hline$M V-21(8)$ & $8 / 4 / 93$ & 31 & 33 & .87 & & & \\
\hline MV-10(28) & $8 / 11 / 94$ & 59 & 59 & .00 & & & \\
\hline$M V-56(34)$ & $8 / 9 / 94$ & 37 & 37 & .00 & & & \\
\hline MV-38(44) & $7 / 24 / 95$ & 40 & 38 & .73 & & & \\
\hline MV-55(60) & $7 / 26 / 95$ & 35 & 35 & .00 & & & \\
\hline \multicolumn{8}{|c|}{ Magnesium } \\
\hline $\mathrm{MV}-4(8)$ & $8 / 13 / 90$ & 25 & 23 & 1.39 & & & \\
\hline $\mathrm{MV}-24(28)$ & $8 / 12 / 91$ & 34 & 34 & .00 & & & \\
\hline$M V-40(34)$ & $8 / 15 / 91$ & 15 & 15 & .00 & & & \\
\hline MV-46(44) & $6 / 23 / 92$ & 13 & 14 & 1.18 & & 14 & 14.5 \\
\hline$M V-36(60)$ & $7 / 29 / 92$ & 16 & 17 & .98 & . & 17 & 17 \\
\hline$M V-21(8)$ & $8 / 4 / 93$ & 16 & 15 & 1.04 & & & \\
\hline$M V-10(28)$ & $8 / 11 / 94$ & 23 & 24 & .71 & & & \\
\hline MV-56(34) & $8 / 9 / 94$ & 16 & 16 & .00 & & & \\
\hline$M V-38(44)$ & $7 / 24 / 95$ & 13 & 13 & .00 & & & \\
\hline$M V-55(60)$ & $7 / 26 / 95$ & 15 & 15 & .00 & & & \\
\hline \multicolumn{8}{|c|}{ Sodium } \\
\hline$M V-4(8)$ & $8 / 13 / 90$ & 54 & 49 & 1.57 & & & \\
\hline$M V-24(28)$ & $8 / 12 / 91$ & 88 & 89 & .19 & & 84 & 80 \\
\hline$M V-40(34)$ & $8 / 15 / 91$ & 18 & 18 & .00 & & 16 & na \\
\hline$M V-46(44)$ & $6 / 23 / 92$ & 14 & 14 & .00 & & 15 & 16 \\
\hline$M V-36(60)$ & $7 / 29 / 92$ & 17 & 17 & .00 & & 18 & 19 \\
\hline MV-21(8) & $8 / 4 / 93$ & 17 & 16 & .66 & & & \\
\hline $\mathrm{MV}-10(28)$ & $8 / 11 / 94$ & 50 & 50 & .00 & & & \\
\hline MV-56(34) & $8 / 9 / 94$ & 20 & 20 & .00 & & & \\
\hline$M V-38(44)$ & $7 / 24 / 95$ & 15 & 15 & .00 & & & \\
\hline MV-55(60) & $7 / 26 / 95$ & 19 & 19 & .00 & & & \\
\hline
\end{tabular}


Table 3. Results of replicate pairs of samples from selected wells and springs, eastern Snake River Plain, analyzed for major ions-Continued

\begin{tabular}{|c|c|c|c|c|c|c|c|}
\hline \multirow{2}{*}{$\begin{array}{c}\text { Site } \\
\text { identifier }\end{array}$} & \multirow{2}{*}{$\begin{array}{c}\text { Date } \\
\text { sampled }\end{array}$} & \multicolumn{2}{|c|}{$\begin{array}{l}\text { Dissolved concentration, } \\
\text { NWQL } \\
(\mathrm{mg} / \mathrm{L})\end{array}$} & \multirow[b]{2}{*}{ Z-value } & \multirow[b]{2}{*}{ Remark } & \multicolumn{2}{|c|}{$\begin{array}{l}\text { Total concentration, } \\
\text { IDHWL } \\
(\mathbf{m g} / \mathbf{L})\end{array}$} \\
\hline & & MV & QA & & & MV & QA \\
\hline \multicolumn{8}{|c|}{ Potassium } \\
\hline$M V-4(8)$ & $8 / 13 / 90$ & 4.8 & 4.4 & 1.16 & & & \\
\hline $\mathrm{MV}-24(28)$ & $8 / 12 / 91$ & 8.3 & 8.2 & .18 & & & \\
\hline$M V-40(34)$ & $8 / 15 / 91$ & 3.3 & 3.2 & .37 & & & \\
\hline MV-46(44) & $6 / 23 / 92$ & 3.3 & 3.3 & .00 & & 3.3 & 3.4 \\
\hline MV-36(60) & $7 / 29 / 92$ & 3.1 & 3.1 & .00 & & 3.4 & 3.4 \\
\hline MV-21(8) & $8 / 4 / 93$ & 3.9 & 5.1 & 2.09 & $\mathrm{~N}$ & & \\
\hline$M V-10(28)$ & $8 / 11 / 94$ & 6.4 & 5.4 & 1.40 & & & \\
\hline MV-56(34) & $8 / 9 / 94$ & 3.5 & 3.5 & .00 & & & \\
\hline MV-38(44) & $7 / 24 / 95$ & 2.9 & 3.0 & .24 & & & \\
\hline$M V-55(60)$ & $7 / 26 / 95$ & 3.5 & 3.5 & .00 & & & \\
\hline \multicolumn{8}{|c|}{ Sulfate } \\
\hline$M V-4(8)$ & $8 / 13 / 90$ & 67 & 66 & .17 & & & \\
\hline$M V-24(28)$ & $8 / 12 / 91$ & 90 & 95 & .68 & & 102 & 102 \\
\hline $\mathrm{MV}-40(34)$ & $8 / 15 / 91$ & 26 & 27 & .29 & & 24 & na \\
\hline MV-46(44) & $6 / 23 / 92$ & 22 & 21 & .32 & & 19 & 20 \\
\hline$M V-36(60)$ & $7 / 29 / 92$ & 26 & 26 & .00 & & 23 & 22 \\
\hline$M V-21(8)$ & $8 / 4 / 93$ & 24 & 26 & .60 & & & \\
\hline MV-10(28) & $8 / 11 / 94$ & 72 & 71 & .16 & & & \\
\hline MV-56(34) & $8 / 9 / 94$ & 36 & 37 & .25 & & & \\
\hline MV-38(44) & $7 / 24 / 95$ & 18 & 17 & .35 & & & \\
\hline MV-55(60) & $7 / 26 / 95$ & 34 & 34 & .00 & & & \\
\hline \multicolumn{8}{|c|}{ Chloride } \\
\hline$M V-4(8)$ & $8 / 13 / 90$ & 61 & 60 & .26 & & & \\
\hline MV-24(28) & $8 / 12 / 91$ & 100 & 110 & 1.61 & & 101 & 101 \\
\hline $\mathrm{MV}-40(34)$ & $8 / 15 / 91$ & 13 & 13 & .00 & & 12 & na \\
\hline$M V-46(44)$ & $6 / 23 / 92$ & 9.4 & 9.3 & .09 & & 9 & 9 \\
\hline MV-36(60) & $7 / 29 / 92$ & 12 & 12 & .00 & & 10 & 28 \\
\hline MV-21(8) & $8 / 4 / 93$ & 10 & 10 & .00 & & & \\
\hline MV-10(28) & $8 / 11 / 94$ & 66 & 66 & .00 & & & \\
\hline MV-56(34) & $8 / 9 / 94$ & 23 & 24 & .55 & & & \\
\hline MV-38(44) & $7 / 24 / 95$ & 8 & 8 & .00 & & & \\
\hline MV-55(60) & $7 / 26 / 95$ & 23 & 22 & .56 & & & \\
\hline
\end{tabular}


Table 3. Results of replicate pairs of samples from selected wells and springs, eastern Snake River Plain, analyzed for major ions-Continued

\begin{tabular}{|c|c|c|c|c|c|c|c|}
\hline \multirow{2}{*}{$\begin{array}{c}\text { Site } \\
\text { identifier }\end{array}$} & \multirow{2}{*}{$\begin{array}{c}\text { Date } \\
\text { sampled }\end{array}$} & \multicolumn{2}{|c|}{$\begin{array}{c}\text { Dissolved concentration, } \\
\text { NWQL } \\
(\mathrm{mg} / \mathrm{L})\end{array}$} & \multirow[b]{2}{*}{ Z-value } & \multirow[b]{2}{*}{ Remark } & \multicolumn{2}{|c|}{$\begin{array}{l}\text { Total concentration, } \\
\text { IDHWL } \\
(\mathrm{mg} / \mathbf{L})\end{array}$} \\
\hline & & MV & QA & & & MV & QA \\
\hline \multicolumn{8}{|c|}{ Fluoride } \\
\hline MV-4(8) & $8 / 13 / 90$ & .5 & .4 & .09 & & & \\
\hline MV-24(28) & $8 / 12 / 91$ & .4 & .4 & .00 & & .41 & .44 \\
\hline$M V-40(34)$ & $8 / 15 / 91$ & .5 & .4 & .94 & & .50 & na \\
\hline MV-46(44) & $6 / 23 / 92$ & 0.4 & .4 & 0.00 & & .4 & .4 \\
\hline$M V-36(60)$ & $7 / 29 / 92$ & .3 & .3 & .00 & & .29 & .33 \\
\hline$M V-21(8)$ & $8 / 4 / 93$ & .4 & .5 & .94 & & & \\
\hline MV-10(28) & $8 / 11 / 94$ & .5 & .4 & .94 & & & \\
\hline MV-56(34) & $8 / 9 / 94$ & .6 & .6 & .00 & & & \\
\hline MV-38(44) & $7 / 24 / 95$ & .3 & .3 & .00 & & & \\
\hline$M V-55(60)$ & $7 / 26 / 95$ & .6 & .5 & .94 & & & \\
\hline \multicolumn{8}{|c|}{ Bromide } \\
\hline $\mathrm{MV}-4(8)$ & $8 / 13 / 90$ & .12 & .12 & .00 & & & \\
\hline MV-24(28) & $8 / 12 / 91$ & .25 & .25 & .00 & & & \\
\hline MV-40(34) & $8 / 15 / 91$ & .03 & .03 & .00 & & & \\
\hline MV-46(44) & $6 / 23 / 92$ & .02 & .02 & .00 & & & \\
\hline MV-36(60) & $7 / 29 / 92$ & .03 & .04 & .20 & & & \\
\hline$M V-21(8)$ & $8 / 4 / 93$ & .04 & .02 & .45 & & & \\
\hline$M V-10(28)$ & $8 / 11 / 94$ & .15 & .16 & .05 & & & \\
\hline MV-56(34) & $8 / 9 / 94$ & .06 & .06 & .00 & & & \\
\hline MV-38(44) & $7 / 24 / 95$ & .03 & .03 & .00 & & & \\
\hline$M V-55(60)$ & $7 / 26 / 95$ & .05 & .05 & .00 & & & \\
\hline \multicolumn{8}{|c|}{ Silica } \\
\hline $\mathrm{MV}-4(8)$ & $8 / 13 / 90$ & 33 & 33 & .00 & & & \\
\hline $\mathrm{MV}-24(28)$ & $8 / 12 / 91$ & 34 & 34 & .00 & & & \\
\hline MV-40(34) & $8 / 15 / 91$ & 33 & 33 & .00 & & & \\
\hline MV-46(44) & $6 / 23 / 92$ & 32 & 32 & .00 & & 31 & 31 \\
\hline MV-36(60) & $7 / 29 / 92$ & 29 & 29 & .00 & & 28.3 & 28.4 \\
\hline MV-21(8) & $8 / 4 / 93$ & 33 & 33 & .00 & & & \\
\hline MV-10(28) & $8 / 11 / 94$ & 34 & 34 & .00 & & & \\
\hline MV-56(34) & $8 / 9 / 94$ & 32 & 32 & .00 & & & \\
\hline MV-38(44) & $7 / 24 / 95$ & 31 & 31 & .00 & & & \\
\hline MV-55(60) & $7 / 26 / 95$ & 33 & 33 & .00 & & & \\
\hline
\end{tabular}


Table 4. Results of replicate pairs of samples from selected wells and springs, eastern Snake River Plain, analyzed for dissolved nutrients and cyanide

[Analyses performed by the U.S. Geological Survey National Water Quality Laboratory. Site identifier: water-quality sample identifier followed by quality-assurance identifier in parentheses; see figure 2 for location of sites. Z-value: see section on statistical comparisons for explanation. Remark: no entry, analytical results of replicate pairs are statistically equivalent; 1 , statistical equivalence of the analytical results of replicate pairs is indeterminate. Abbreviations: $\mathrm{mg} / \mathrm{L}$, milligram per liter; $M V$, water-quality sample; QA, quality assurance replicate sample. Symbol: <, the result was less than the indicated reporting level]

\begin{tabular}{|c|c|c|c|c|c|}
\hline \multirow{2}{*}{$\begin{array}{c}\text { Site } \\
\text { identifier }\end{array}$} & \multirow{2}{*}{$\begin{array}{c}\text { Date } \\
\text { sampled }\end{array}$} & \multicolumn{2}{|c|}{$\begin{array}{c}\text { Concentration } \\
(\mathrm{mg} / \mathrm{L})\end{array}$} & \multirow[b]{2}{*}{ Z-value } & \multirow[b]{2}{*}{ Remark } \\
\hline & & MV & QA & & \\
\hline \multicolumn{6}{|c|}{ Nitrite, as nitrogen } \\
\hline $\mathrm{MV}-27(28)$ & $8 / 15 / 89$ & $<0.01$ & $<0.01$ & 0 & \\
\hline $\mathrm{MV}-7(8)$ & $8 / 16 / 89$ & $<.01$ & $<.01$ & 0 & \\
\hline MV-33(34) & $8 / 17 / 89$ & $<.01$ & $<.01$ & 0 & \\
\hline$M V-43(44)$ & $8 / 22 / 89$ & $<.01$ & $<.01$ & 0 & \\
\hline MV-61(60) & $9 / 14 / 89$ & $<.01$ & $<.01$ & 0 & \\
\hline$M V-4(8)$ & $8 / 13 / 90$ & $<.01$ & $<.01$ & 0 & \\
\hline MV-24(28) & $8 / 12 / 91$ & $<.01$ & $<.01$ & 0 & \\
\hline$M V-40(34)$ & $8 / 15 / 91$ & $<.01$ & $<.01$ & 0 & \\
\hline MV-46(44) & $6 / 23 / 92$ & $<.01$ & $<.01$ & 0 & \\
\hline MV-36(60) & $7 / 29 / 92$ & $<.01$ & $<.01$ & 0 & \\
\hline MV-21(8) & $8 / 4 / 93$ & $<.01$ & $<.01$ & 0 & \\
\hline MV-10(28) & $8 / 11 / 94$ & $<.01$ & $<.01$ & 0 & \\
\hline MV-56(34) & $8 / 9 / 94$ & $<.01$ & $<.01$ & 0 & \\
\hline MV-38(44) & $7 / 24 / 95$ & $<.01$ & $<.01$ & 0 & \\
\hline MV-55(60) & $7 / 26 / 95$ & $<.01$ & $<.01$ & 0 & \\
\hline \multicolumn{6}{|c|}{ Nitrite plus nitrate, as nitrogen } \\
\hline MV-27(28) & $8 / 15 / 89$ & 1.5 & 1.5 & .00 & \\
\hline $\mathrm{MV}-7(8)$ & $8 / 16 / 89$ & .40 & .45 & 1.09 & \\
\hline MV-33(34) & $8 / 17 / 89$ & .53 & .54 & .20 & \\
\hline MV-43(44) & $8 / 22 / 89$ & 4.3 & 4.3 & .00 & \\
\hline MV-61(60) & $9 / 14 / 89$ & .98 & .97 & .15 & \\
\hline$M V-4(8)$ & $8 / 13 / 90$ & 1.8 & 1.9 & 1.03 & \\
\hline MV-24(28) & $8 / 12 / 91$ & 5.7 & 5.7 & .00 & \\
\hline MV-40(34) & $8 / 15 / 91$ & .69 & .67 & .36 & \\
\hline MV-46(44) & $6 / 23 / 92$ & .62 & .62 & .19 & \\
\hline MV-36(60) & $7 / 29 / 92$ & 1.6 & 1.7 & 1.11 & \\
\hline MV-21(8) & $8 / 4 / 93$ & 1.0 & 1.0 & .00 & \\
\hline MV-10(28) & $8 / 11 / 94$ & 2.6 & 2.6 & .00 & \\
\hline MV-56(34) & $8 / 9 / 94$ & 1.0 & 1.0 & .00 & \\
\hline MV-38(44) & $7 / 24 / 95$ & 1.4 & 1.3 & .63 & \\
\hline MV-55(60) & $7 / 26 / 95$ & .99 & 1.0 & .08 & \\
\hline
\end{tabular}


Table 4. Results of replicate pairs of samples from selected wells and springs, eastern Snake River Plain, analyzed for dissolved nutrients and cyanide-Continued

\begin{tabular}{|c|c|c|c|c|c|}
\hline \multirow{2}{*}{$\begin{array}{c}\text { Site } \\
\text { identifier }\end{array}$} & \multirow{2}{*}{$\begin{array}{c}\text { Date } \\
\text { sampled }\end{array}$} & \multicolumn{2}{|c|}{$\begin{array}{c}\text { Concentration } \\
(\mathrm{mg} / \mathrm{L})\end{array}$} & \multirow[b]{2}{*}{ Z-value } & \multirow[b]{2}{*}{ Remark } \\
\hline & & MV & QA & & \\
\hline \multicolumn{6}{|c|}{ Ammonia, as nitrogen } \\
\hline $\mathrm{MV}-27(28)$ & $8 / 15 / 89$ & 0.01 & 0.01 & 0.00 & \\
\hline MV-7(8) & $8 / 16 / 89$ & $<.01$ & $<.01$ & 0 & \\
\hline MV-33(34) & $8 / 17 / 89$ & $<.01$ & $<.01$ & 0 & \\
\hline MV-43(44) & $8 / 22 / 89$ & $<.01$ & $<.01$ & 0 & \\
\hline$M V-61(60)$ & $9 / 14 / 89$ & .01 & .01 & .00 & \\
\hline$M V-4(8)$ & $8 / 13 / 90$ & $<.01$ & $<.01$ & 0 & \\
\hline $\mathrm{MV}-24(28)$ & $8 / 12 / 91$ & $<.01$ & $<.01$ & 0 & \\
\hline$M V-40(34)$ & $8 / 15 / 91$ & $<.01$ & $<.01$ & 0 & \\
\hline$M V-46(44)$ & $6 / 23 / 92$ & $<.01$ & $<.01$ & 0 & \\
\hline$M V-36(60)$ & $7 / 29 / 92$ & .01 & .01 & .00 & \\
\hline MV-21(8) & $8 / 4 / 93$ & .01 & .01 & .00 & \\
\hline MV-10(28) & $8 / 11 / 94$ & .01 & .02 & .44 & \\
\hline $\mathrm{MV}-56(34)$ & $8 / 9 / 94$ & .01 & .02 & .44 & \\
\hline MV-38(44) & $7 / 24 / 95$ & .03 & .03 & .00 & \\
\hline MV-55(60) & $7 / 26 / 95$ & .03 & $<.015$ & .64 & \\
\hline \multicolumn{6}{|c|}{ Orthophosphate, as phosphorus } \\
\hline $\mathrm{MV}-27(28)$ & $8 / 15 / 89$ & .01 & .02 & & I \\
\hline MV-7(8) & $8 / 16 / 89$ & .01 & .01 & .00 & \\
\hline MV-33(34) & $8 / 17 / 89$ & .01 & $<.01$ & & I \\
\hline$M V-43(44)$ & $8 / 22 / 89$ & .01 & .01 & .00 & \\
\hline MV-61(60) & $9 / 14 / 89$ & $<.01$ & $<.01$ & 0 & \\
\hline$M V-4(8)$ & $8 / 13 / 90$ & .01 & $<.01$ & & I \\
\hline MV-24(28) & $8 / 12 / 91$ & .01 & .01 & .00 & \\
\hline MV-40(34) & $8 / 15 / 91$ & .02 & .02 & .00 & \\
\hline MV-46(44) & $6 / 23 / 92$ & $<.01$ & $<.01$ & 0 & \\
\hline MV-36(60) & $7 / 29 / 92$ & .03 & .03 & .00 & \\
\hline MV-21(8) & $8 / 4 / 93$ & .01 & .01 & .00 & \\
\hline MV-10(28) & $8 / 11 / 94$ & $<.01$ & .01 & & I \\
\hline MV-56(34) & $8 / 9 / 94$ & .01 & .03 & & I \\
\hline MV-38(44) & $7 / 24 / 95$ & .03 & .03 & .00 & \\
\hline$M V-55(60)$ & $7 / 26 / 95$ & .01 & .01 & .00 & \\
\hline \multicolumn{6}{|c|}{ Cyanide } \\
\hline$M V-4(8)$ & $8 / 13 / 90$ & $<.01$ & $<.01$ & 0 & \\
\hline MV-24(28) & $8 / 12 / 91$ & $<.01$ & $<.01$ & 0 & \\
\hline MV-46(44) & $6 / 23 / 92$ & $<.01$ & $<.01$ & 0 & \\
\hline$M V-36(60)$ & $7 / 29 / 92$ & $<.01$ & $<.01$ & 0 & \\
\hline
\end{tabular}


Table 5. Results of replicate pairs of samples from selected wells and springs, eastern Snake River Plain, analyzed for trace elements

[Analyses performed by the U.S. Geological Survey National Water Quality Laboratory (NWQL) and the Idaho Department of Health and Welfare Laboratory (IDHWL). Site identifier: water-quality sample identifier followed by quality-assurance identifier in parentheses; see figure 2 for location of sites. Z-value: see section on statistical comparisons for explanation. Remark: no entry, analytical results of replicate pairs are statistically equivalent; $\mathrm{N}$, analytical results are not statistically equivalent; $\mathrm{I}$, statistical equivalence of the analytical results of replicate pairs is indeterminate. Abbreviations: $\mu \mathrm{g} / \mathrm{L}$, microgram per liter; MV, water-quality sample; QA, quality-assurance replicate sample; na, no analysis. Symbol: $<$, the resut was less than the stated value]

\begin{tabular}{|c|c|c|c|c|c|c|c|c|c|c|c|c|c|}
\hline \multirow{2}{*}{$\begin{array}{c}\text { Site } \\
\text { identifier }\end{array}$} & \multirow{2}{*}{$\begin{array}{c}\text { Date } \\
\text { sampled }\end{array}$} & \multicolumn{2}{|c|}{$\begin{array}{c}\text { Dissolved concentration } \\
\text { NWQL } \\
(\mu \mathrm{g} / \mathrm{L})\end{array}$} & \multirow[b]{2}{*}{ Z-value } & \multirow[b]{2}{*}{ Remark } & \multicolumn{2}{|c|}{$\begin{array}{c}\text { Total concentration, } \\
\text { NWQL } \\
(\mu \mathrm{g} / \mathbf{L})\end{array}$} & \multirow[b]{2}{*}{ Z-value } & \multirow[b]{2}{*}{ Remark } & \multicolumn{2}{|c|}{$\begin{array}{c}\text { Dissolved concentration, } \\
\text { IDHWL } \\
(\mu \mathrm{g} / \mathrm{L})\end{array}$} & \multicolumn{2}{|c|}{$\begin{array}{l}\text { Total concentration, } \\
\text { IDHWL } \\
(\mu \mathrm{g} / \mathrm{L})\end{array}$} \\
\hline & & MV & $\mathbf{Q A}$ & & & MV & QA & & & MV & QA & MV & QA \\
\hline \multicolumn{14}{|c|}{ Aluminum } \\
\hline MV-4(8) & $8 / 13 / 90$ & $<10$ & $<10$ & 0 & '. & & & & & & & & \\
\hline$M V-24(28)$ & $8 / 12 / 91$ & $<10$ & $<10$ & 0 & & & & & & & & & \\
\hline MV-40(34) & $8 / 15 / 91$ & 20 & $<10$ & 2.04 & $\mathrm{~N}$ & & & & & & & & \\
\hline MV-43(44) & $6 / 23 / 92$ & $<10$ & $<10$ & 0 & & & & & & $<100$ & $<100$ & & \\
\hline MV-36(60) & $7 / 29 / 92$ & 20 & 10 & 2.04 & $\mathrm{~N}$ & & & & & $<100$ & $<100$ & & \\
\hline MV-21(8) & $8 / 4 / 93$ & $<10$ & 20 & 2.04 & $\mathrm{~N}$ & & & & & & & & \\
\hline MV-10(28) & $8 / 11 / 94$ & $<10$ & $<10$ & 0 & & & & & & & & & \\
\hline MV-56(34) & $8 / 9 / 94$ & $<10$ & $<10$ & 0 & & & & & & & & & \\
\hline MV-38(44) & $7 / 24 / 95$ & $<10$ & $<10$ & 0 & & & & & & & & & \\
\hline MV-55(60) & $7 / 26 / 95$ & 20 & 20 & .00 & & & & & & & & & \\
\hline \multicolumn{14}{|c|}{ Arsenic } \\
\hline MV-27(28) & $8 / 15 / 89$ & 2 & 2 & .00 & & & & & & . & & & \\
\hline MV-7(8) & $8 / 16 / 89$ & 2 & 2 & .00 & & & & & & & & & \\
\hline$M V-33(34)$ & $8 / 17 / 89$ & 2 & 2 & .00 & & & & & & & & & \\
\hline$M V-43(44)$ & $8 / 22 / 89$ & 2 & 2 & .00 & & & & & & & & & \\
\hline MV-61(60) & $9 / 14 / 89$ & 3 & 3 & .00 & & & & & & & & & \\
\hline MV-4(8) & $8 / 13 / 90$ & 3 & 4 & .70 & & & & & & & & & \\
\hline MV-24(28) & $8 / 12 / 91$ & 3 & 3 & .00 & & & & & & $<10$ & $<10$ & $<10$ & $<10$ \\
\hline$M V-40(34)$ & $8 / 15 / 91$ & 2 & 2 & .00 & & & & & & $<10$ & na & $<10$ & na \\
\hline MV-46(44) & $6 / 23 / 92$ & 2 & 2 & .00 & & & & & & $<10$ & $<10$ & & \\
\hline MV-36(60) & $7 / 29 / 92$ & 2 & 2 & .00 & & & & & & $<10$ & $<10$ & & \\
\hline MV-21(8) & $8 / 4 / 93$ & 2 & 2 & .00 & & & & & & & & & \\
\hline
\end{tabular}


Table 5. Results of replicate pairs of samples from selected wells and springs, eastern Snake River Plain, analyzed for trace elements-Continued

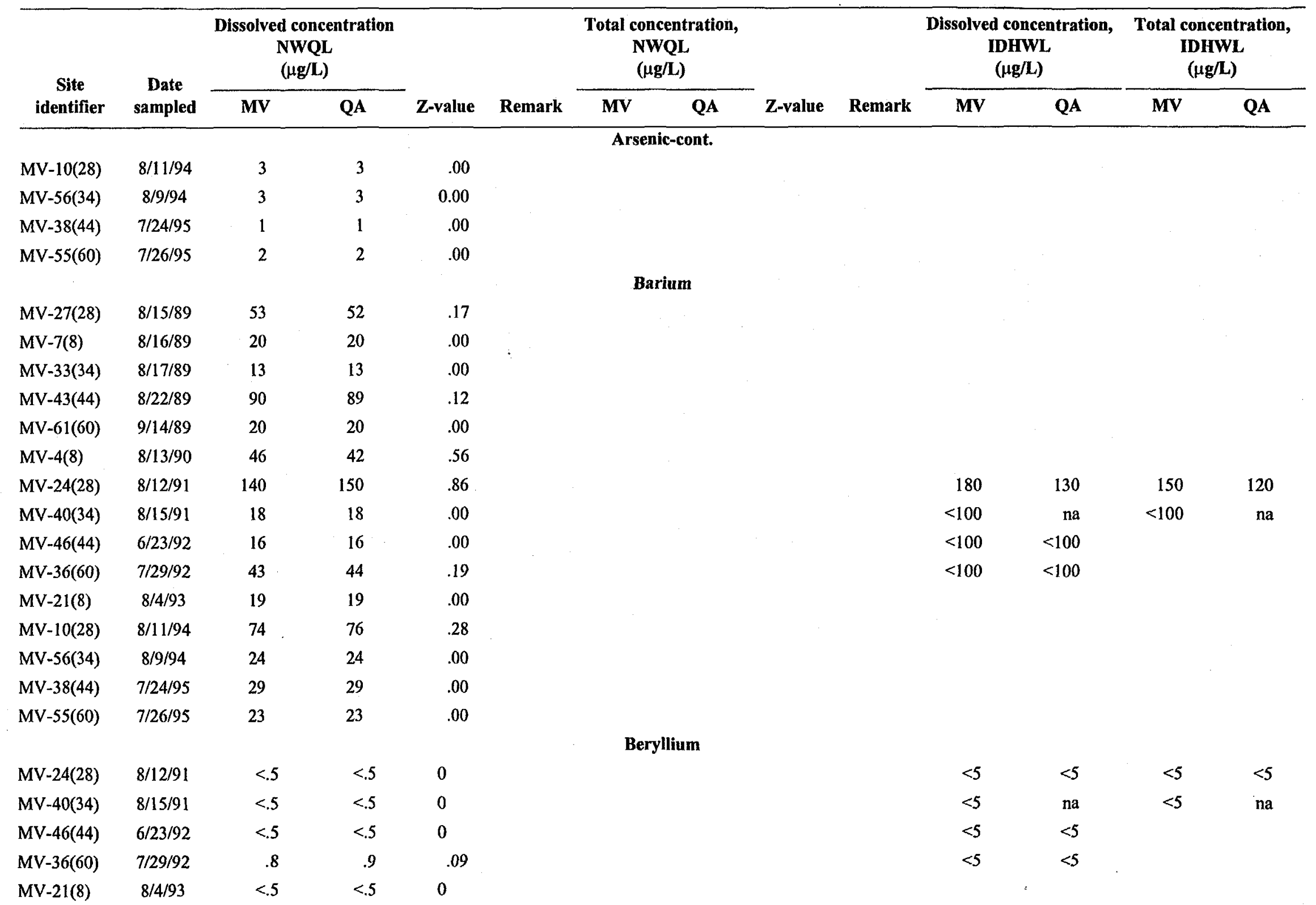


Table 5. Results of replicate pairs of samples from selected wells and springs, eastern Snake River Plain, analyzed for trace elements-Continued

\begin{tabular}{|c|c|c|c|c|c|c|c|c|c|c|c|c|c|}
\hline \multirow{2}{*}{$\begin{array}{c}\text { Site } \\
\text { Identifier }\end{array}$} & \multirow{2}{*}{$\begin{array}{c}\text { Date } \\
\text { sampled }\end{array}$} & \multicolumn{2}{|c|}{$\begin{array}{c}\text { Dissolved concentration } \\
\text { NWQL } \\
(\mu g / L)\end{array}$} & \multirow[b]{2}{*}{ Z-value } & \multirow[b]{2}{*}{ Remark } & \multicolumn{2}{|c|}{$\begin{array}{l}\text { Total concentration, } \\
\text { NWQL } \\
(\mu \mathrm{g} / \mathrm{L})\end{array}$} & \multirow[b]{2}{*}{ Z-value } & \multirow[b]{2}{*}{ Remark } & \multicolumn{2}{|c|}{$\begin{array}{c}\text { Dissolved concentration, } \\
\text { DHWL } \\
(\mu g / L)\end{array}$} & \multicolumn{2}{|c|}{$\begin{array}{c}\text { Total concentration, } \\
\text { IDHWL } \\
(\mu \mathrm{g} / \mathrm{L})\end{array}$} \\
\hline & & MV & QA & & & MV & QA & & & MV & QA & MV & QA \\
\hline & & & & & & Beryl & cont. & & & & & & \\
\hline MV-10(28) & $8 / 11 / 94$ & $<.5$ & $<.5$ & 0 & & & & & & & & & \\
\hline MV-56(34 & 8/9/94 & $<0.5$ & 0.7 & 0.17 & & & & & & & & & \\
\hline MV-38(44) & $7 / 24 / 95$ & $<.5$ & .5 & 0 & & & & & & & & & \\
\hline \multirow[t]{2}{*}{$M V-55(60)$} & $7 / 26 / 95$ & $<.5$ & $<.5$ & 0 & & & & & & & & & \\
\hline & & & & & \multicolumn{3}{|c|}{ Cadmium } & & & & & & \\
\hline MV-27(28) & $8 / 15 / 89$ & $<1$ & $<1$ & 0 & & & & & & & & & \\
\hline MV-7(8) & $8 / 16 / 89$ & $<1$ & $<1$ & 0 & & & & & & & & & \\
\hline MV-33(34) & $8 / 17 / 89$ & $<1$ & $<1$ & 0 & & & & & & & & & \\
\hline MV-43(44) & $8 / 22 / 89$ & $<1$ & $<1$ & 0 & & & & & & & & & \\
\hline$M V-61(60)$ & $9 / 14 / 89$ & $<1$ & $<1$ & 0 & & & & & & & & & \\
\hline MV-4(8) & $8 / 13 / 90$ & $<1$ & $<1$ & 0 & & & & & & & & & \\
\hline MV-24(28) & $8 / 12 / 91$ & $<1$ & $<1$ & 0 & & & & & & $<1$ & $<1$ & $<1$ & $<1$ \\
\hline$M V-40(34)$ & $8 / 15 / 91$ & $<1$ & $<1$ & 0 & & & & & & $<1$ & $<1$ & $<1$ & na \\
\hline$M V-46(44)$ & $6 / 23 / 92$ & $<1$ & $<1$ & 0 & & & & & & $<1$ & $<1$ & & \\
\hline MV-36(60) & $7 / 29 / 92$ & $<1$ & $<1$ & 0 & & & & & & $<1$ & $<1$ & & \\
\hline MV-21(8) & $8 / 4 / 93$ & $<1$ & $<1$ & 0 & & & & & & & & & \\
\hline MV-10(28) & $8 / 11 / 94$ & $<1$ & 1 & 0 & & & & & & & & & \\
\hline MV-56(34) & $8 / 9 / 94$ & $<1$ & $<1$ & 0 & & & & $\cdot$ & & & & & \\
\hline MV-38(44) & $7 / 24 / 95$ & $<1$ & $<1$ & 0 & & & & & & & & & \\
\hline$M V-55(60)$ & $7 / 26 / 95$ & $<1$ & $<1$ & 0 & & & & & & & & & \\
\hline \multicolumn{14}{|c|}{ Chromium } \\
\hline MV-27(28) & $8 / 15 / 89$ & 3 & 2 & .30 & & & & & & & & & \\
\hline MV-7(8) & $8 / 16 / 89$ & 3 & 3 & .00 & & & & & & & & & \\
\hline MV-33(34) & $8 / 17 / 89$ & 4 & 4 & .00 & & & & & & & & & \\
\hline MV-43(44) & $8 / 22 / 89$ & 2 & 2 & .00 & & & & & & & & & \\
\hline MV-61(60) & $9 / 14 / 89$ & 5 & 5 & .00 & & & & & & & & & \\
\hline
\end{tabular}


Table 5. Results of replicate pairs of samples from selected wells and springs, eastern Snake River Plain, analyzed for trace elements-Continued

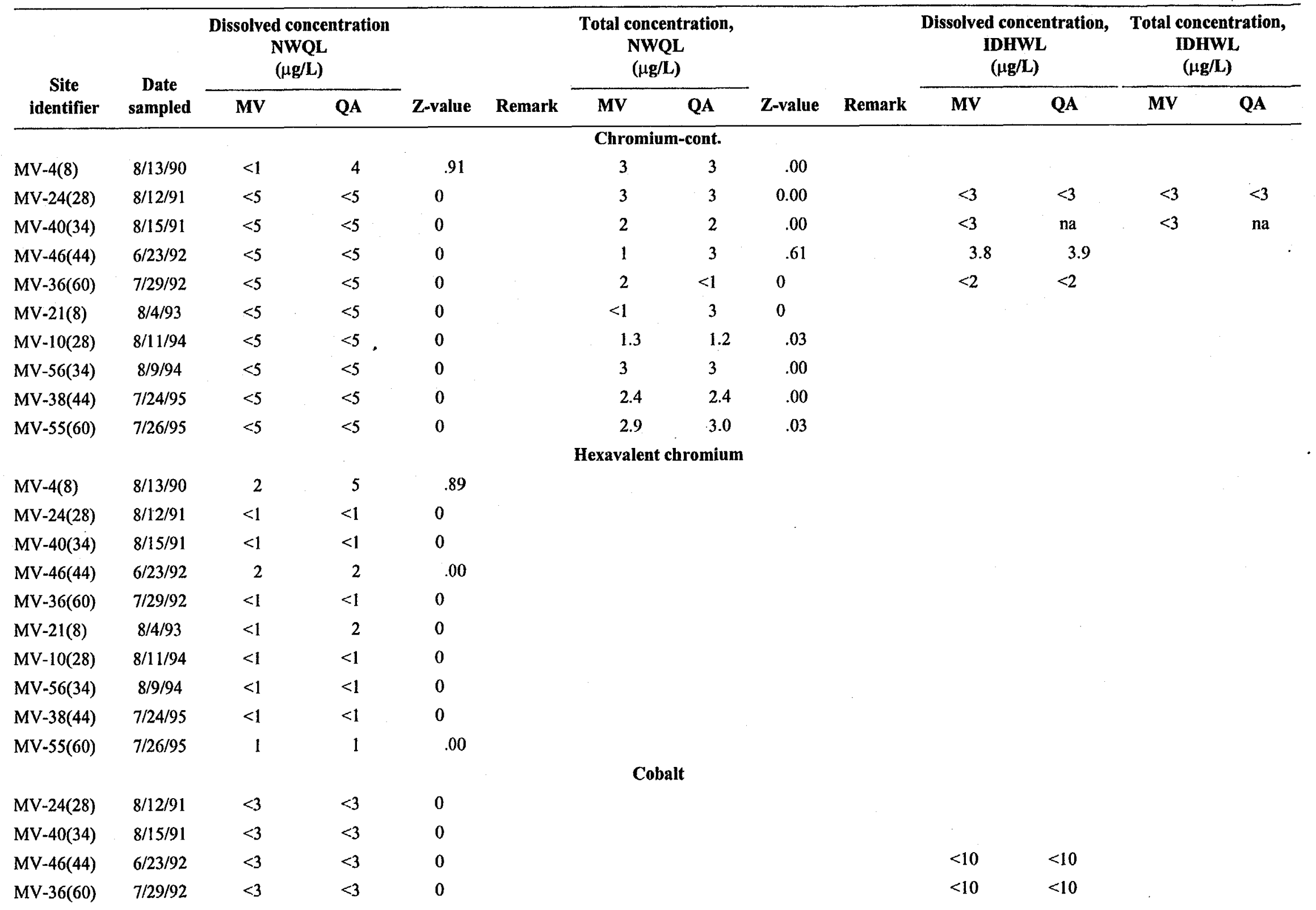


Table 5. Results of replicate pairs of samples from selected wells and springs, eastern Snake RIver Plain, analyzed for trace elements-Continued

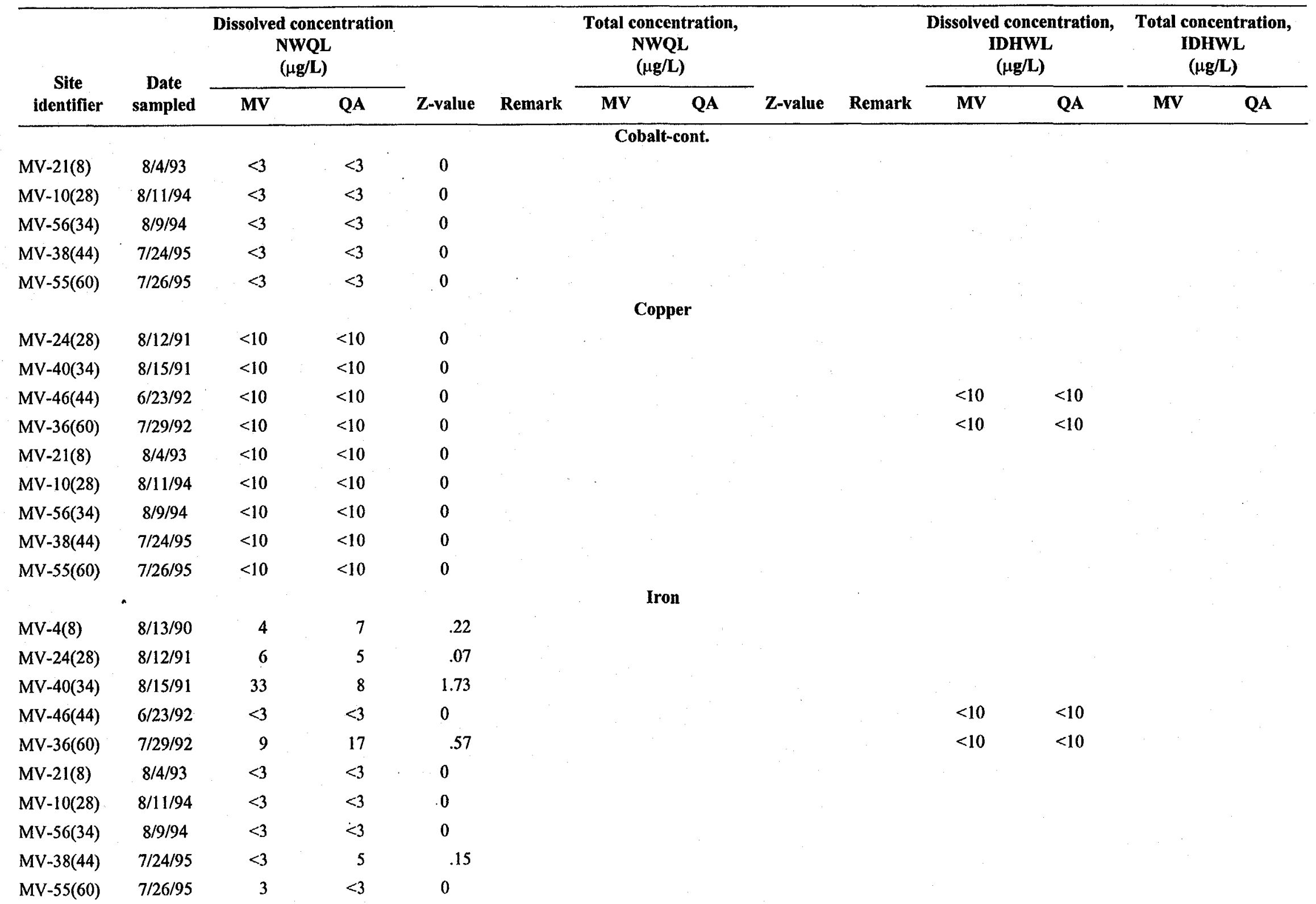


Table 5. Results of replicate pairs of samples from selected wells and springs, eastern Snake River Plain, analyzed for trace elements-Continued

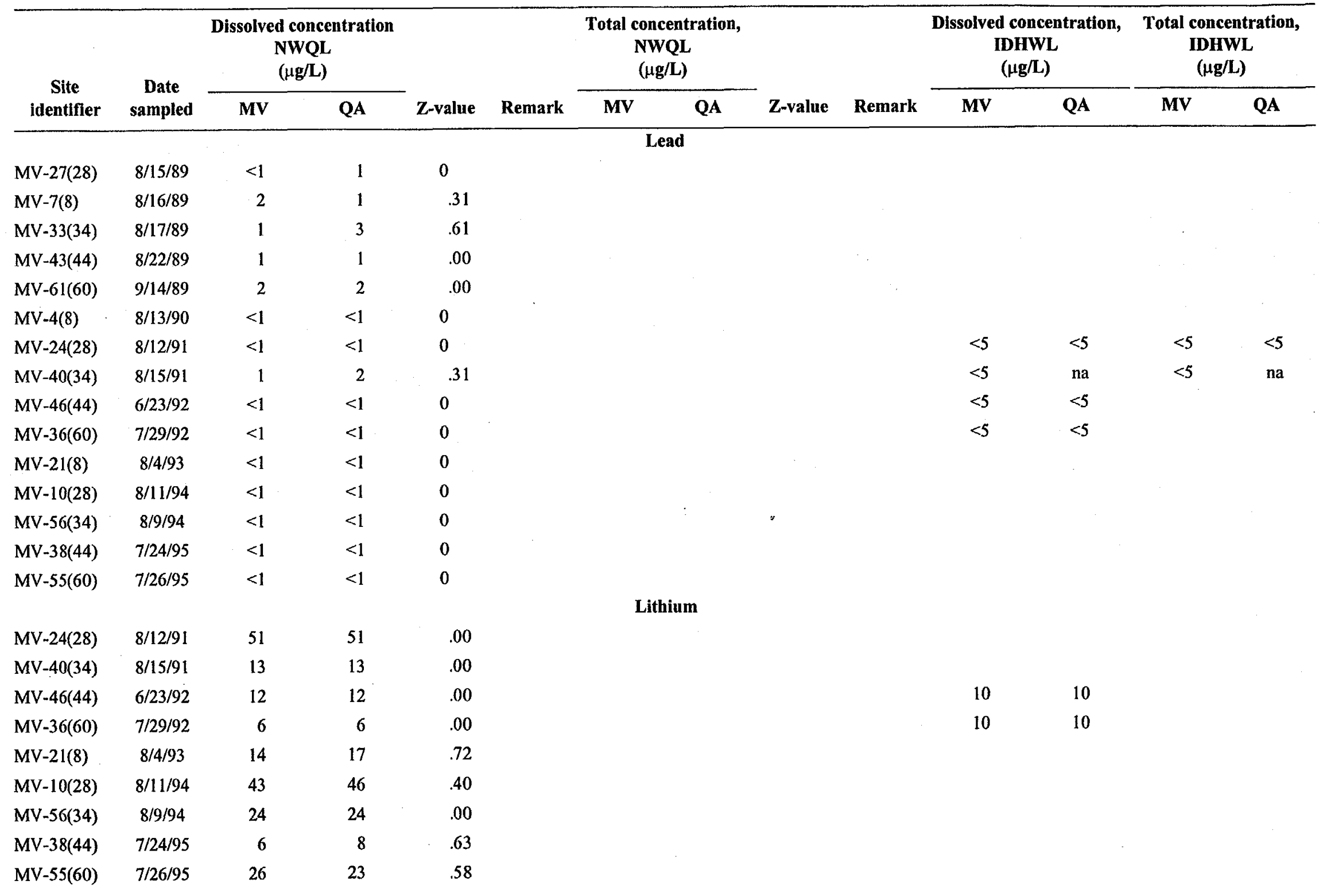




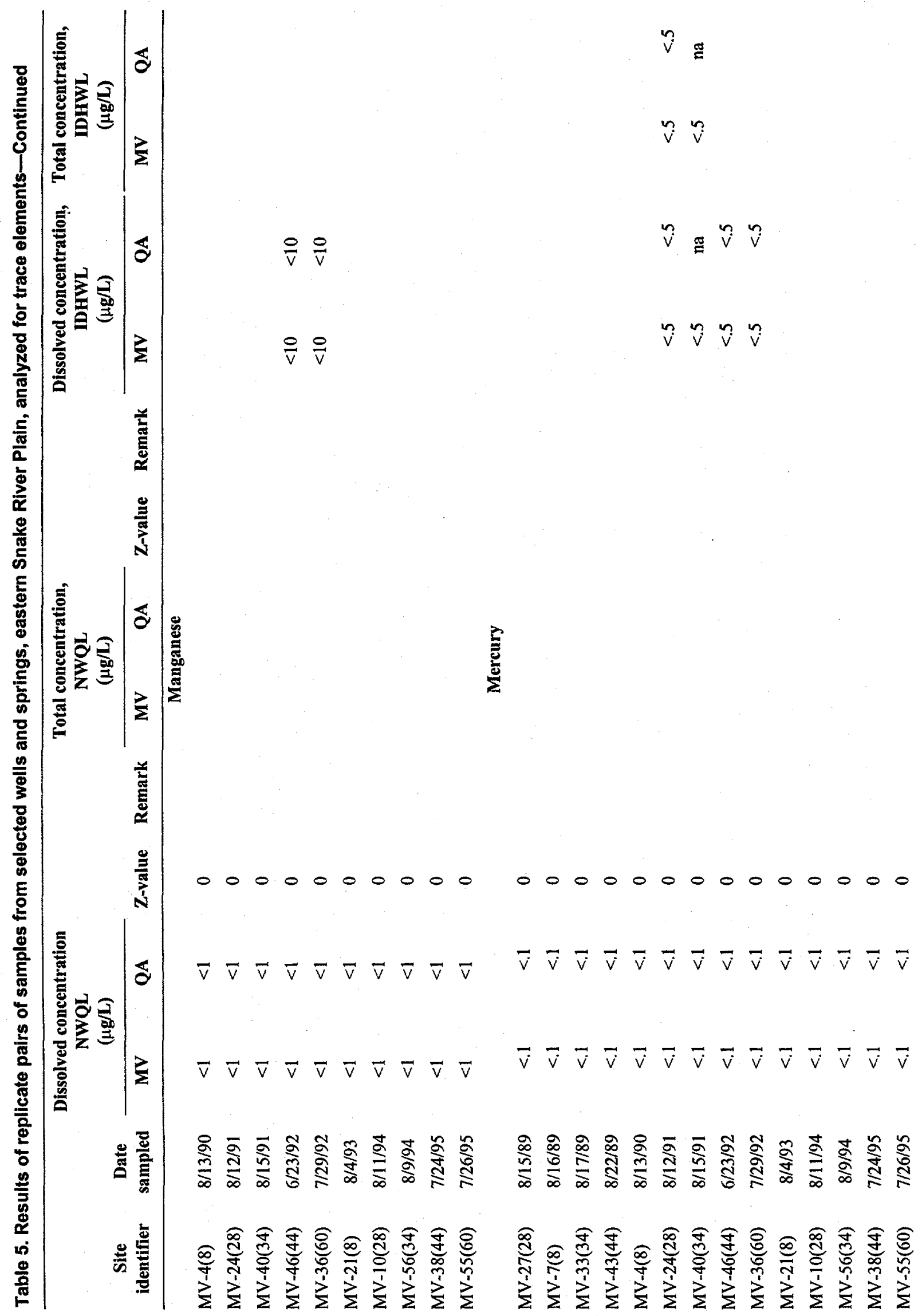


Table 5. Results of replicate pairs of samples from selected wells and springs, eastern Snake River Plain, analyzed for trace elements-Continued

\begin{tabular}{|c|c|c|c|c|c|c|c|c|c|c|c|c|c|}
\hline \multirow{2}{*}{$\begin{array}{c}\text { Site } \\
\text { identifier }\end{array}$} & \multirow{2}{*}{$\begin{array}{c}\text { Date } \\
\text { sampled }\end{array}$} & \multicolumn{2}{|c|}{$\begin{array}{c}\text { Dissolved concentration } \\
\text { NWQL } \\
(\mu \mathrm{g} / \mathrm{L})\end{array}$} & \multirow[b]{2}{*}{ Z-value } & \multirow[b]{2}{*}{ Remark } & \multicolumn{2}{|c|}{$\begin{array}{c}\text { Total concentration, } \\
\text { NWQL } \\
(\mu \mathrm{g} / \mathrm{L})\end{array}$} & \multirow[b]{2}{*}{ Z-value } & \multirow[b]{2}{*}{ Remark } & \multicolumn{2}{|c|}{$\begin{array}{c}\text { Dissolved concentration, } \\
\text { IDHWL } \\
(\mu \mathrm{g} / \mathrm{L})\end{array}$} & \multicolumn{2}{|c|}{$\begin{array}{c}\text { Total concentration, } \\
\text { IDHWL } \\
(\mu \mathrm{g} / \mathrm{L})\end{array}$} \\
\hline & & MV & QA & & & MV & $\mathbf{Q A}$ & & & MV & QA & MV & QA \\
\hline \multicolumn{14}{|c|}{ Molybdenum } \\
\hline MV-24(28) & $8 / 12 / 91$ & $<10$ & $<10$ & 0 & & & & & & & & & \\
\hline MV-40(34) & $8 / 15 / 91$ & $<10$ & $<10$ & 0 & & & & & & & & & \\
\hline MV-46(44) & $6 / 23 / 92$ & 10 & $<10$ & 0 & & & & & & $<10$ & $<10$ & & \\
\hline MV-36(60) & $7 / 29 / 92$ & $<10$ & $<10$ & 0 & & & & & & $<10$ & $<10$ & & \\
\hline MV-21(8) & $8 / 4 / 93$ & $<10$ & $<10$ & 0 & & & & & & & & & \\
\hline MV-10(28) & $8 / 11 / 94$ & $<10$ & $<10$ & 0 & & & & 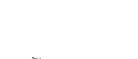 & & & & & \\
\hline MV-56(34) & $8 / 9 / 94$ & $<10$ & $<10$ & 0 & & & & & & & & & \\
\hline MV-38(44) & $7 / 24 / 95$ & $<10$ & $<10$ & 0 & & & & & & & & & \\
\hline MV-55(60) & $7 / 26 / 95$ & $<10$ & $<10$ & 0 & & & & & & & & & \\
\hline \multicolumn{14}{|c|}{ Nickel } \\
\hline$M V-24(28)$ & $8 / 12 / 91$ & $<10$ & $<10$ & 0 & & & & & & & & & \\
\hline MV-40(34) & $8 / 15 / 91$ & $<10$ & $<10$ & 0 & & & & & & & & & \\
\hline MV-46(44) & $6 / 23 / 92$ & $<10$ & $<10$ & 0 & & & & & & $<10$ & $<10$ & & \\
\hline$M V-36(60)$ & $7 / 29 / 92$ & $<10$ & $<10$ & 0 & & & & & & $<10$ & $<10$ & & \\
\hline$M V-21(8)$ & $8 / 4 / 93$ & $<10$ & $<10$ & 0 & & & & & & & & & \\
\hline MV-10(28) & $8 / 11 / 94$ & $<10$ & $<10$ & 0 & & & & & & & & & \\
\hline MV-56(34) & $8 / 9 / 94$ & $<10$ & $<10$ & 0 & & & & & & & & & \\
\hline MV-38(44) & $7 / 24 / 95$ & $<10$ & $<10$ & 0 & & & & & & & & & \\
\hline MV-55(60) & $7 / 26 / 95$ & $<10$ & $<10$ & 0 & & & & & & & & & \\
\hline \multicolumn{14}{|c|}{ Selenium } \\
\hline MV-27(28) & $8 / 15 / 89$ & 1 & $<1$ & 0 & & & & & & & & & \\
\hline MV-7(8) & $8 / 16 / 89$ & $<1$ & $<1$ & 0 & & & & & & & & & \\
\hline MV-33(34) & $8 / 17 / 89$ & $<1$ & $<1$ & 0 & & & & & & & & & \\
\hline MV-43(44) & $8 / 22 / 89$ & $<1$ & $<1$ & 0 & & & & & & & & & \\
\hline MV-61(60) & $9 / 14 / 89$ & 1 & 1 & .00 & & & & & & & & & \\
\hline MV-4(8) & $8 / 13 / 90$ & $<1$ & $<1$ & 0 & & & & & & & & & \\
\hline
\end{tabular}


Table 5. Results of replicate pairs of samples from selected wells and springs, eastern Snake River Plain, analyzed for trace elements-Continued

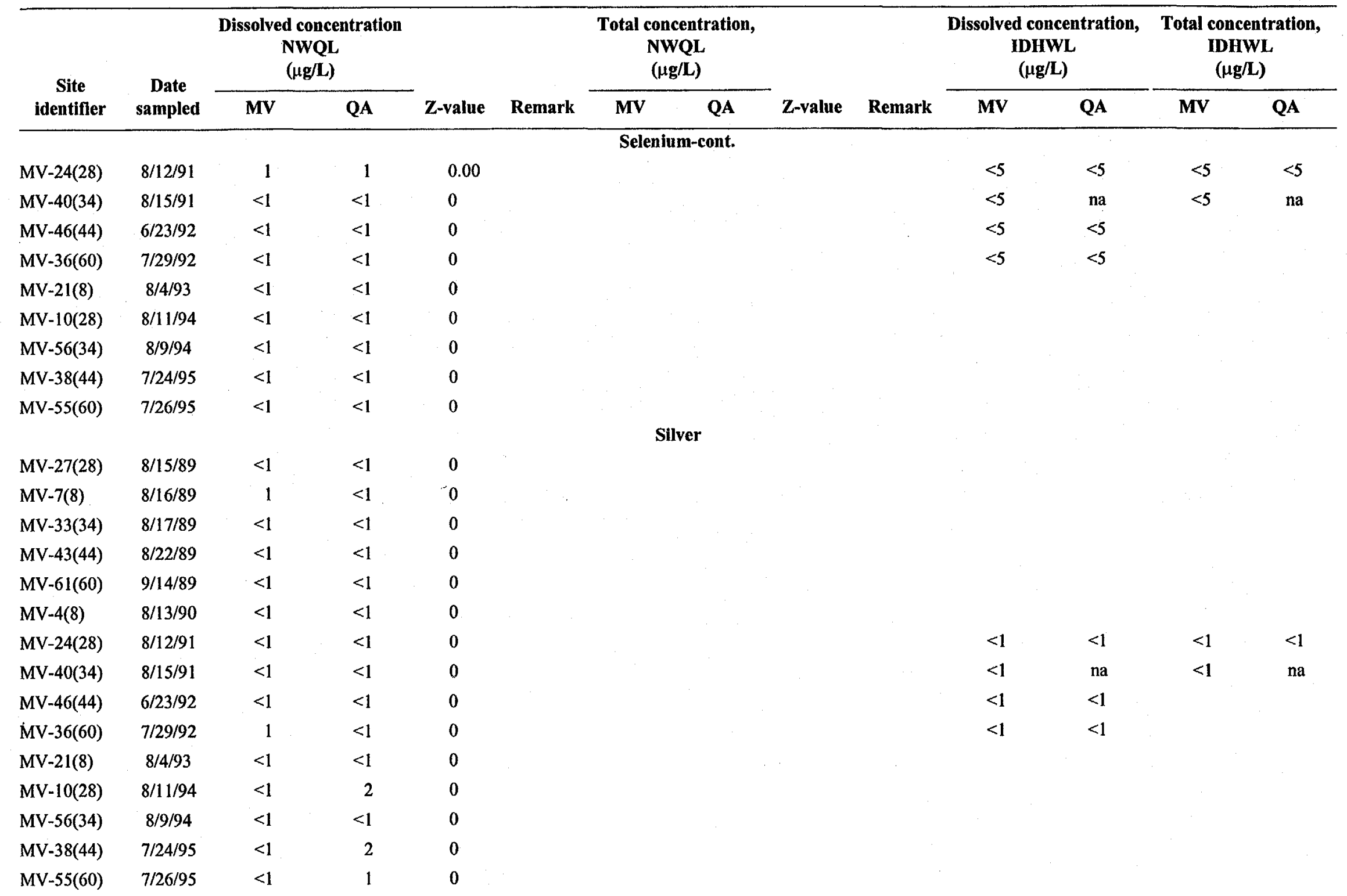


Table 5. Results of replicate pairs of samples from selected wells and springs, eastern Snake River Plain, analyzed for trace elements-Continued

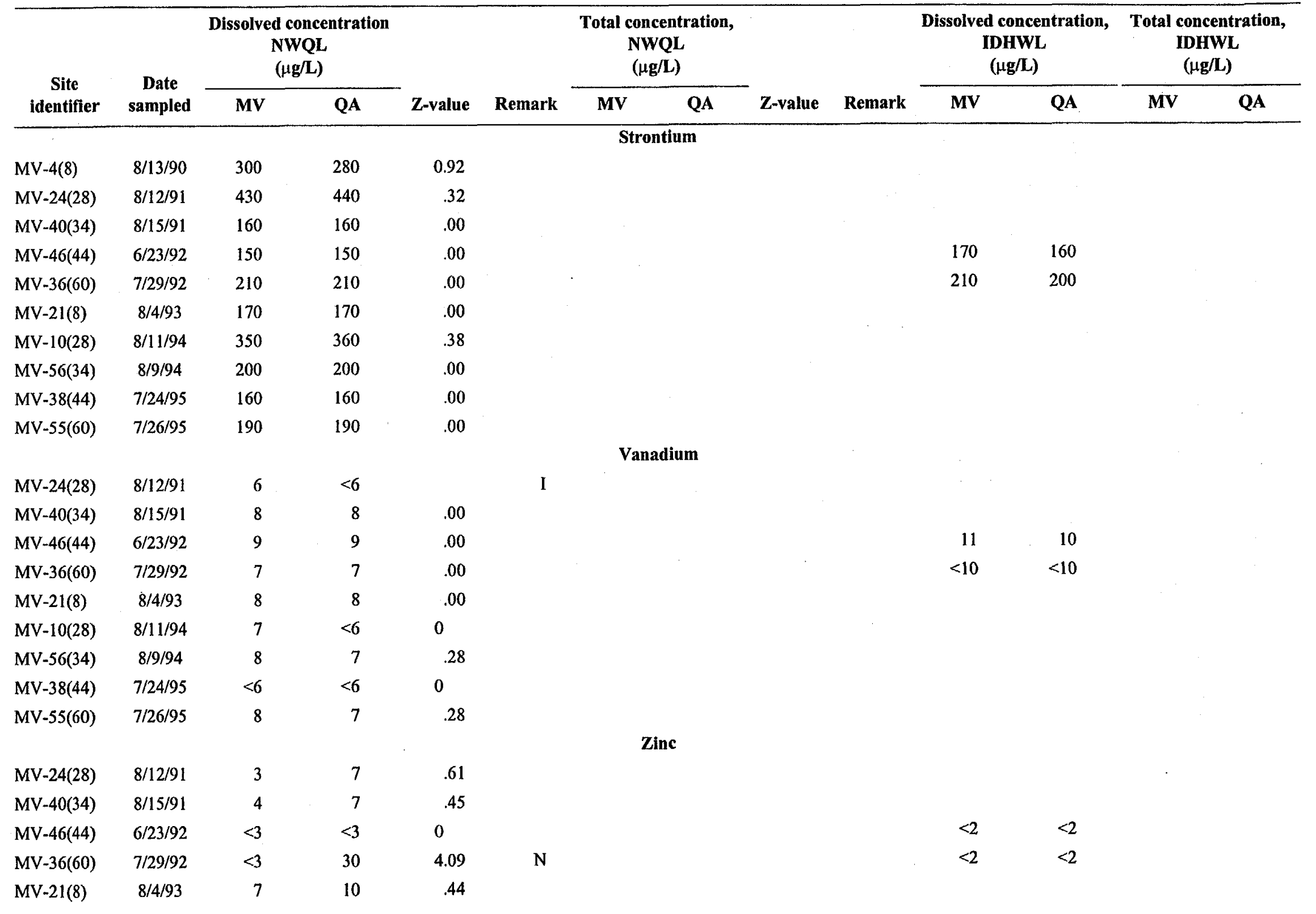


Table 5. Results of replicate pairs of samples from selected wells and springs, eastern Snake River Plain, analyzed for trace elements-Continued

\begin{tabular}{|c|c|c|c|c|c|c|c|c|c|c|c|c|c|}
\hline \multirow{2}{*}{$\begin{array}{c}\text { Site } \\
\text { identifier }\end{array}$} & \multirow{2}{*}{$\begin{array}{c}\text { Date } \\
\text { sampled }\end{array}$} & \multicolumn{2}{|c|}{$\begin{array}{c}\text { Dissolved concentration } \\
\text { NWQL } \\
(\mu \mathrm{g} / \mathrm{L})\end{array}$} & \multirow[b]{2}{*}{ Z-value } & \multirow[b]{2}{*}{ Remark } & \multicolumn{2}{|c|}{$\begin{array}{c}\text { Total concentration, } \\
\text { NWQL } \\
(\mu \mathrm{g} / \mathrm{L})\end{array}$} & \multirow[b]{2}{*}{ Z-value } & \multirow[b]{2}{*}{ Remark } & \multicolumn{2}{|c|}{$\begin{array}{c}\text { Dissolved concentration, } \\
\text { IDHWL } \\
(\mu \mathrm{g} / \mathrm{L})\end{array}$} & \multicolumn{2}{|c|}{$\begin{array}{l}\text { Total concentration, } \\
\text { IDHWL } \\
(\mu \mathrm{g} / \mathrm{L})\end{array}$} \\
\hline & & MV & $\mathbf{Q A}$ & & & MV & QA & & & MV & QA & MV & $\mathbf{Q A}$ \\
\hline \multicolumn{14}{|c|}{ Zinc-cont. } \\
\hline$M V-10(28)$ & $8 / 11 / 94$ & $<3$ & $<3$ & 0 & & & & & & & & & \\
\hline MV-56(34) & $8 / 9 / 94$ & 30 & 28 & .24 & & & & & & & & & \\
\hline MV-38(44) & $7 / 24 / 95$ & 6 & 5 & .15 & & & & & & & & & \\
\hline MV-55(60) & $7 / 26 / 95$ & 7 & $<3$ & .61 & & & & & & & & & \\
\hline
\end{tabular}


Table 6. Results of replicate pairs of samples from selected wells and springs, eastern Snake River Plain, analyzed for gross radioactivity and radionuclides

[Analyses performed by the U.S. Geological Survey National Water Quality Laboratory (NWQL) and the Idaho State University (ISU) Environmental Monitoring Laboratory. Site identifier: water-quality sample identifier followed by quality-assurance identifier in parentheses; see figure 2 for location of sites. Z-value: see section on statistical comparisons for explanation. Remark: no entry, analytical results of replicate pairs are statistically equivalent; $N$, the analytical results are not statistically equivalent. Uncertainties are reported as the two-sigma precision estimate. Abbreviations: $\mathrm{pCi} / \mathrm{L}$, picocurie per liter; $\mu \mathrm{g} / \mathrm{L}$, microgram per liter; $\mathrm{MV}$, waterquality sample; QA, quality-assurance replicate sample)

\begin{tabular}{|c|c|c|c|c|c|}
\hline \multirow{2}{*}{$\begin{array}{c}\text { Site } \\
\text { identifier }\end{array}$} & \multirow{2}{*}{$\begin{array}{c}\text { Date } \\
\text { sampled }\end{array}$} & \multicolumn{2}{|c|}{ Concentration } & \multirow[b]{2}{*}{ Z-value } & \multirow[b]{2}{*}{ Remark } \\
\hline & & MV & QA & & \\
\hline \multicolumn{6}{|c|}{ Gross alpha radioactivity, as dissolved thorium-230, NWQL (pCi/L) } \\
\hline MV-27(28) & $8 / 15 / 89$ & $4.09 \pm 0.80$ & $2.45 \pm 0.56$ & 3.36 & $\mathrm{~N}$ \\
\hline $\mathrm{MV}-7(8)$ & $8 / 16 / 89$ & $2.46 \pm 0.62$ & $1.91 \pm 0.87$ & 1.03 & \\
\hline MV-33(34) & $8 / 17 / 89$ & $.681 \pm 0.462$ & $2.07 \pm 0.51$ & 4.04 & $\mathrm{~N}$ \\
\hline MV-43(44) & $8 / 22 / 89$ & $5.01 \pm 0.92$ & $5.56 \pm 1.00$ & .81 & \\
\hline $\mathrm{MV}-61(60)$ & $9 / 14 / 89$ & $11.2 \pm 1.6$ & $2.94 \pm 0.63$ & 9.61 & $\mathrm{~N}$ \\
\hline$M V-4(8)$ & $8 / 13 / 90$ & $4.07 \pm 1.09$ & $2.79 \pm 0.845$ & 1.86 & \\
\hline $\mathrm{MV}-24(28)$ & $8 / 12 / 91$ & $3.53 \pm 1.00$ & $3.69 \pm 1.03$ & .22 & \\
\hline$M V-40(34)$ & $8 / 15 / 91$ & $1.63 \pm 0.691$ & $1.66 \pm 0.689$ & .06 & \\
\hline$M V-46(44)$ & $6 / 23 / 92$ & $1.10 \pm 0.535$ & $1.27 \pm 0.554$ & .44 & \\
\hline MV-36(60) & $7 / 29 / 92$ & $2.10 \pm 0.699$ & $2.39 \pm 0.801$ & .55 & \\
\hline MV-21(8) & $8 / 4 / 93$ & $1.93 \pm 1.11$ & $1.79 \pm 1.12$ & .18 & \\
\hline MV-10(28) & $8 / 11 / 94$ & $3.22 \pm 2.14$ & $2.32 \pm 1.97$ & .62 & \\
\hline MV-56(34) & $8 / 9 / 94$ & $1.11 \pm 1.01$ & $1.58 \pm 1.15$ & .61 & \\
\hline MV-38(44) & $7 / 24 / 95$ & $1.62 \pm 2.26$ & $1.01 \pm 2.08$ & .40 & \\
\hline$M V-55(60)$ & $7 / 26 / 95$ & $-.808 \pm 1.44$ & $3.20 \pm 2.71$ & 2.71 & $\mathrm{~N}$ \\
\hline \multicolumn{6}{|c|}{ Gross alpha radioactivity, as dissolved uranium, NWQL ( $\mu \mathrm{g} / \mathrm{L})$} \\
\hline MV-27(28) & $8 / 15 / 89$ & $3.73 \pm 0.73$ & $2.24 \pm 0.51$ & 3.35 & $\mathrm{~N}$ \\
\hline MV-7(8) & $8 / 16 / 89$ & $2.22 \pm 0.56$ & $1.73 \pm 0.79$ & 1.01 & \\
\hline MV-33(34) & $8 / 17 / 89$ & $.623 \pm 0.423$ & $1.90 \pm 0.46$ & 4.09 & $\mathrm{~N}$ \\
\hline MV-43(44) & $8 / 22 / 89$ & $4.62 \pm 0.85$ & $5.06 \pm 0.91$ & .71 & \\
\hline MV-61(60) & $9 / 14 / 89$ & $10.2 \pm 1.5$ & $2.69 \pm 0.57$ & 9.36 & $\mathbf{N}$ \\
\hline MV-4(8) & $8 / 13 / 90$ & $5.62 \pm 1.51$ & $4.04 \pm 1.22$ & 1.63 & \\
\hline MV-24(28) & $8 / 12 / 91$ & $4.86 \pm 1.38$ & $5.28 \pm 1.46$ & .42 & \\
\hline MV-40(34) & $8 / 15 / 91$ & $2.34 \pm 0.987$ & $2.38 \pm 0.982$ & .06 & \\
\hline$M V-46(44)$ & $6 / 23 / 92$ & $1.79 \pm 0.843$ & $1.84 \pm 0.798$ & .09 & \\
\hline$M V-36(60)$ & $7 / 29 / 92$ & $3.07 \pm 1.03$ & $3.40 \pm 1.13$ & .43 & \\
\hline MV-21(8) & $8 / 4 / 93$ & $2.75 \pm 1.59$ & $2.34 \pm 1.47$ & .38 & \\
\hline $\mathrm{MV}-10(28)$ & $8 / 11 / 94$ & $4.46 \pm 2.97$ & $3.64 \pm 3.09$ & .38 & \\
\hline MV-56(34) & $8 / 9 / 94$ & $1.59 \pm 1.45$ & $2.23 \pm 1.63$ & .59 & \\
\hline MV-38(44) & $7 / 24 / 95$ & $2.12 \pm 2.95$ & $1.32 \pm 2.72$ & .40 & \\
\hline MV-55(60) & $7 / 26 / 95$ & $-1.05 \pm 1.87$ & $4.28 \pm 3.65$ & 2.60 & $\mathrm{~N}$ \\
\hline
\end{tabular}


Table 6. Results of replicate pairs of samples from selected wells and springs, eastern Snake River Plain, analyzed for gross radioactivity and radionuclides-Continued

\begin{tabular}{|c|c|c|c|c|c|}
\hline \multirow{2}{*}{$\begin{array}{c}\text { Site } \\
\text { identifier }\end{array}$} & \multirow{2}{*}{$\begin{array}{c}\text { Date } \\
\text { sampled }\end{array}$} & \multicolumn{2}{|c|}{ Concentration } & \multirow[b]{2}{*}{ Z-value } & \multirow[b]{2}{*}{ Remark } \\
\hline & & MV & QA & & \\
\hline \multicolumn{6}{|c|}{ Gross alpha radioactivity, as suspended uranium, NWQL $(\mu \mathrm{g} / \mathrm{L})$} \\
\hline $\mathrm{MV}-27(28)$ & $8 / 15 / 89$ & $0.025 \pm 0.042$ & $0.007 \pm 0.015$ & 0.81 & \\
\hline MV-7(8) & $8 / 16 / 89$ & $.006 \pm 0.013$ & $-.003 \pm 0.046$ & .38 & \\
\hline MV-33(34) & $8 / 17 / 89$ & $.031 \pm 0.042$ & $.034 \pm 0.030$ & .14 & \\
\hline $\mathrm{MV}-43(44)$ & $8 / 22 / 89$ & $.003 \pm 0.033$ & $.025 \pm 0.041$ & .84 & \\
\hline $\mathrm{MV}-61(60)$ & $9 / 14 / 89$ & $.148 \pm 0.080$ & $-.032 \pm 0.081$ & 3.16 & $\mathbf{N}$ \\
\hline MV-4(8) & $8 / 13 / 90$ & $-.276 \pm 0.318$ & $-.166 \pm 0.278$ & .52 & \\
\hline MV-24(28) & $8 / 12 / 91$ & $-.121 \pm 0.235$ & $-.120 \pm 0.232$ & .01 & \\
\hline $\mathrm{MV}-40(34)$ & $8 / 15 / 91$ & $-.230 \pm 0.281$ & $-.117 \pm 0.228$ & .62 & \\
\hline MV-46(44) & $6 / 23 / 92$ & $-.302 \pm 0.384$ & $.010 \pm 0.387$ & 1.14 & \\
\hline$M V-36(60)$ & $7 / 29 / 92$ & $.084 \pm 0.253$ & $-.094 \pm 0.365$ & .80 & \\
\hline \multicolumn{6}{|c|}{ Gross alpha radioactivity, as suspended thorium-230, NWQL (pCi/L) } \\
\hline MV-27(28) & $8 / 15 / 89$ & $.025 \pm 0.041$ & $.007 \pm 0.015$ & .82 & \\
\hline $\mathrm{MV}-7(8)$ & $8 / 16 / 89$ & $.006 \pm 0.012$ & $-.003 \pm 0.046$ & .38 & \\
\hline MV-33(34) & $8 / 17 / 89$ & $.030 \pm 0.041$ & $.033 \pm 0.030$ & .12 & \\
\hline$M V-43(44)$ & $8 / 22 / 89$ & $.003 \pm 0.032$ & $.024 \pm 0.040$ & .85 & \\
\hline$M V-61(60)$ & $9 / 14 / 89$ & $.145 \pm 0.078$ & $-.031 \pm 0.080$ & 3.17 & $\mathrm{~N}$ \\
\hline $\mathrm{MV}-4(8)$ & $8 / 13 / 90$ & $-.148 \pm 0.180$ & $-.087 \pm 0.150$ & .52 & \\
\hline $\mathrm{MV}-24(28)$ & $8 / 12 / 91$ & $-.066 \pm 0.130$ & $-.063 \pm 0.124$ & .03 & \\
\hline $\mathrm{MV}-40(34)$ & $8 / 15 / 91$ & $-.130 \pm 0.166$ & $-.065 \pm 0.128$ & .62 & \\
\hline $\mathrm{MV}-46(44)$ & $6 / 23 / 92$ & $-.163 \pm 0.213$ & $.005 \pm 0.203$ & 1.14 & \\
\hline$M V-36(60)$ & $7 / 29 / 92$ & $.046 \pm 0.142$ & $-.050 \pm 0.197$ & .79 & \\
\hline \multicolumn{6}{|c|}{ Gross alpha radioactivity, as total americium-241, ISU (pCi/L) } \\
\hline $\mathrm{MV}-24(28)$ & $8 / 12 / 91$ & $-2.4 \pm 3.0$ & $-4.2 \pm 3.2$ & .82 & \\
\hline MV-46(44) & $6 / 23 / 92$ & $0 \pm 2$ & $0 \pm 2$ & .00 & \\
\hline$M V-36(60)$ & $7 / 29 / 92$ & $0 \pm 2$ & $0 \pm 2$ & .00 & \\
\hline MV-21(8) & $8 / 4 / 93$ & $1 \pm 1$ & $1 \pm 1$ & .00 & \\
\hline MV-10(28) & $8 / 11 / 94$ & $1 \pm 4$ & $-2 \pm 1.0$ & 1.46 & \\
\hline MV-56(34) & $8 / 9 / 94$ & $2 \pm 3$ & $0 \pm 2$ & 1.11 & \\
\hline MV-38(44) & $7 / 24 / 95$ & $2 \pm 5$ & $0 \pm 5$ & .57 & \\
\hline MV $-55(60)$ & $7 / 26 / 95$ & $-2 \pm 5$ & $-3 \pm 5$ & .28 & \\
\hline \multicolumn{6}{|c|}{ Gross beta radioactivity, as dissolved cesium-137, NWQL ( $\mathrm{pCi} / \mathrm{L})$} \\
\hline $\mathrm{MV}-27(28)$ & $8 / 15 / 89$ & $6.81 \pm 1.04$ & $6.47 \pm 1.17$ & .43 & \\
\hline $\mathrm{MV}-7(8)$ & $8 / 16 / 89$ & $4.62 \pm 0.77$ & $3.37 \pm 0.65$ & 2.48 & $\mathrm{~N}$ \\
\hline MV-33(34) & $8 / 17 / 89$ & $4.82 \pm 0.78$ & $4.92 \pm 0.77$ & .18 & \\
\hline $\mathrm{MV}-43(44)$ & $8 / 22 / 89$ & $10.10 \pm 1.71$ & $11.9 \pm 2.0$ & 1.37 & \\
\hline
\end{tabular}


Table 6. Results of replicate pairs of samples from selected wells and springs, eastern Snake River Plain, analyzed for gross radioactivity and radionuclides-Continued

\begin{tabular}{|c|c|c|c|c|c|}
\hline \multirow{2}{*}{$\begin{array}{c}\text { Site } \\
\text { identifier }\end{array}$} & \multirow{2}{*}{$\begin{array}{c}\text { Date } \\
\text { sampled }\end{array}$} & \multicolumn{2}{|c|}{ Concentration } & \multirow[b]{2}{*}{ Z-value } & \multirow[b]{2}{*}{ Remark } \\
\hline & & MV & QA & & \\
\hline \multicolumn{6}{|c|}{ Gross beta radioactivity, as dissolved cesium-137, NWQL (pCi/L)-cont. } \\
\hline MV-61(60) & $9 / 14 / 89$ & $4.65 \pm 0.85$ & $3.86 \pm 0.72$ & 1.42 & \\
\hline $\mathrm{MV}-4(8)$ & $8 / 13 / 90$ & $7.38 \pm 1.67$ & $5.94 \pm 1.40$ & 1.32 & \\
\hline MV-24(28) & $8 / 12 / 91$ & $10.6 \pm 2.59$ & $11.9 \pm 2.86$ & .67 & \\
\hline MV-40(34) & $8 / 15 / 91$ & $4.11 \pm 1.19$ & $4.36 \pm 1.25$ & .29 & \\
\hline$M V-46(44)$ & $6 / 23 / 92$ & $4.17 \pm 1.25$ & $2.79 \pm 0.959$ & 1.75 & \\
\hline MV-36(60) & $7 / 29 / 92$ & $4.80 \pm 1.18$ & $4.63 \pm 1.17$ & .20 & \\
\hline MV-21(8) & $8 / 4 / 93$ & $3.65 \pm 1.19$ & $5.63 \pm 1.55$ & 2.03 & $\mathbf{N}$ \\
\hline MV-10(28) & $8 / 11 / 94$ & $9.93 \pm 1.96$ & $9.03 \pm 1.88$ & .66 & \\
\hline MV-56(34) & $8 / 9 / 94$ & $5.21 \pm 1.24$ & $4.53 \pm 1.15$ & .80 & \\
\hline MV-38(44) & $7 / 24 / 95$ & $4.71 \pm 3.85$ & $7.57 \pm 4.16$ & 1.01 & \\
\hline$M V-55(60)$ & $7 / 26 / 95$ & $8.46 \pm 4.25$ & $4.39 \pm 3.87$ & 1.42 & \\
\hline
\end{tabular}

Gross beta radioactivity, as dissolved strontium-90 in equilibrium with yttrium-90, NWQL (pCi/L)

$\begin{array}{lccccc}\text { MV-27(28) } & 8 / 15 / 89 & 6.65 \pm 1.02 & 5.67 \pm 1.02 & 1.36 & \\ \text { MV-7(8) } & 8 / 16 / 89 & 3.94 \pm 0.66 & 2.83 \pm 0.54 & 2.60 & \mathrm{~N} \\ \text { MV-33(34) } & 8 / 17 / 89 & 4.30 \pm 0.70 & 4.45 \pm 0.70 & .30 & \\ \text { MV-43(44) } & 8 / 22 / 89 & 8.61 \pm 1.46 & 11.20 \pm 1.90 & 2.16 & \mathrm{~N} \\ \text { MV-61(60) } & 9 / 14 / 89 & 3.96 \pm 0.72 & 3.37 \pm 0.62 & 1.24 & \\ \text { MV-4(8) } & 8 / 13 / 90 & 5.48 \pm 1.24 & 4.51 \pm 1.07 & 1.18 \\ \text { MV-24(28) } & 8 / 12 / 91 & 8.10 \pm 1.98 & 8.91 \pm 2.14 & .56 & \\ \text { MV-40(34) } & 8 / 15 / 91 & 3.02 \pm 0.756 & 3.22 \pm 0.795 & .36 & \\ \text { MV-46(44) } & 6 / 23 / 92 & 3.13 \pm 0.776 & 2.09 \pm 0.652 & 2.05 & \\ \text { MV-36(60) } & 7 / 29 / 92 & 3.66 \pm 0.899 & 3.47 \pm 0.877 & .30 & \\ \text { MV-21(8) } & 8 / 4 / 93 & 2.66 \pm 0.750 & 4.09 \pm 0.912 & 2.42 & \\ \text { MV-10(28) } & 8 / 11 / 94 & 7.48 \pm 1.48 & 6.71 \pm 1.40 & .76 & \\ \text { MV-56(34) } & 8 / 9 / 94 & 3.91 \pm 0.933 & 3.43 \pm 0.869 & .75 & \\ \text { MV-38(44) } & 7 / 24 / 95 & 3.61 \pm 2.90 & 5.81 \pm 3.06 & 1.04 & \\ \text { MV-55(60) } & 7 / 26 / 95 & 6.51 \pm 3.11 & 3.32 \pm 2.88 & 1.51 & \end{array}$

Gross beta radioactivity, as suspended cesium-137, NWQL (pCi/L)

$\begin{array}{lrrrr}\text { MV-27(28) } & 8 / 15 / 89 & -.157 \pm 0.268 & .000 \pm 0.260 & .84 \\ \text { MV-7(8) } & 8 / 16 / 89 & .138 \pm 0.278 & -.137 \pm 0.257 & 1.45 \\ \text { MV-33(34) } & 8 / 17 / 89 & .008 \pm 0.256 & .044 \pm 0.248 & .20 \\ \text { MV-43(44) } & 8 / 22 / 89 & .095 \pm 0.240 & .172 \pm 0.249 & .45 \\ \text { MV-61(60) } & 9 / 14 / 89 & .353 \pm 0.268 & .183 \pm 0.265 & .90 \\ \text { MV-4(8) } & 8 / 13 / 90 & .009 \pm 0.512 & -.207 \pm 0.549 & .58\end{array}$


Table 6. Results of replicate pairs of samples from selected wells and springs, eastern Snake River Plain, analyzed for gross radioactivity and radionuclides-Continued

\begin{tabular}{|c|c|c|c|c|c|}
\hline \multirow{2}{*}{$\begin{array}{c}\text { Site } \\
\text { identifier }\end{array}$} & \multirow{2}{*}{$\begin{array}{c}\text { Date } \\
\text { sampled }\end{array}$} & \multicolumn{2}{|c|}{ Concentration } & \multirow[b]{2}{*}{ Z-value } & \multirow[b]{2}{*}{ Remark } \\
\hline & & $\mathbf{M V}$ & QA & & \\
\hline \multicolumn{6}{|c|}{ Gross beta radioactivity, as suspended cesium-137, NWQL (pCi/L)-cont. } \\
\hline $\mathrm{MV}-24(28)$ & $8 / 12 / 91$ & $0.553 \pm 0.508$ & $0.059 \pm 0.468$ & 1.43 & \\
\hline $\mathrm{MV}-40(34)$ & $8 / 15 / 91$ & $.207 \pm 0.460$ & $-.182 \pm 0.496$ & 1.18 & \\
\hline MV-46(44) & $6 / 23 / 92$ & $.119 \pm 0.511$ & $.308 \pm 0.445$ & .56 & \\
\hline MV-36(60) & $7 / 29 / 92$ & $.481 \pm 0.506$ & $.348 \pm 0.471$ & .38 & \\
\hline \multicolumn{6}{|c|}{ Gross beta radioactivity, as suspended strontium-90 in equilibrium with yttrium-90, NWQL (pCi/L, } \\
\hline $\mathrm{MV}-27(28)$ & $8 / 15 / 89$ & $-.164 \pm 0.280$ & $.000 \pm 0.272$ & .84 & \\
\hline MV-7(8) & $8 / 16 / 89$ & $.144 \pm 0.290$ & $-.143 \pm 0.268$ & 1.45 & \\
\hline MV-33(34) & $8 / 17 / 89$ & $.008 \pm 0.267$ & $.046 \pm 0.259$ & .20 & \\
\hline$M V-43(44)$ & $8 / 22 / 89$ & $.099 \pm 0.251$ & $.180 \pm 0.260$ & .45 & \\
\hline$M V-61(60)$ & $9 / 14 / 89$ & $.357 \pm 0.271$ & $.180 \pm 0.260$ & .94 & \\
\hline MV-4(8) & $8 / 13 / 90$ & $.008 \pm 0.498$ & $-.195 \pm 0.519$ & .56 & \\
\hline $\mathrm{MV}-24(28)$ & $8 / 12 / 91$ & $.529 \pm 0.486$ & $.057 \pm 0.456$ & 1.42 & \\
\hline $\mathrm{MV}-40(34)$ & $8 / 15 / 91$ & $.200 \pm 0.446$ & $-.177 \pm 0.482$ & 1.15 & \\
\hline$M V-46(44)$ & $6 / 23 / 92$ & $.112 \pm 0.483$ & $.295 \pm 0.426$ & .57 & \\
\hline MV-36(60) & $7 / 29 / 92$ & $.460 \pm 0.484$ & $.339 \pm 0.458$ & .36 & \\
\hline \multicolumn{6}{|c|}{ Gross beta radioactivity, as total cesium-137, ISU (pCi/L) } \\
\hline MV-24(28) & $8 / 12 / 91$ & $1.4 \pm 5.0$ & $4.1 \pm 5.0$ & .76 & \\
\hline MV-46(44) & $6 / 23 / 92$ & $2 \pm 4$ & $3 \pm 4$ & .35 & \\
\hline MV-36(60) & $7 / 29 / 92$ & $6 \pm 4$ & $4 \pm 4$ & .71 & \\
\hline MV-21(8) & $8 / 4 / 93$ & $1 \pm 2$ & $5 \pm 2$ & 1.41 & \\
\hline$M V-10(28)$ & $8 / 11 / 94$ & $5 \pm 2$ & $4 \pm 2$ & .71 & \\
\hline MV-56(34) & $8 / 9 / 94$ & $3 \pm 2$ & $2 \pm 2$ & .71 & \\
\hline MV-38(44) & $7 / 24 / 95$ & $3 \pm 2$ & $4 \pm 2$ & .71 & \\
\hline MV-55(60) & $7 / 26 / 95$ & $4 \pm 2$ & $5 \pm 2$ & .71 & \\
\hline \multicolumn{6}{|c|}{ Radon-222, NWQL (pCi/L) } \\
\hline$M V-27(28)$ & $8 / 15 / 89$ & $12 \pm 36$ & $-19 \pm 34$ & 1.25 & \\
\hline $\mathrm{MV}-7(8)$ & $8 / 16 / 89$ & $8 \pm 29$ & $49 \pm 26$ & 2.11 & $\mathrm{~N}$ \\
\hline MV-33(34) & $8 / 17 / 89$ & $43 \pm 47$ & $39 \pm 45$ & .12 & \\
\hline MV-43(44) & $8 / 22 / 89$ & $80 \pm 39$ & $104 \pm 40$ & .86 & \\
\hline MV-61(60) & $9 / 14 / 89$ & $5 \pm 24$ & $-8 \pm 23$ & .78 & \\
\hline$M V-4(8)$ & $8 / 13 / 90$ & $24 \pm 35$ & $31 \pm 24$ & .33 & \\
\hline $\mathrm{MV}-24(28)$ & $8 / 12 / 91$ & $43 \pm 31$ & $81 \pm 32$ & 1.71 & \\
\hline MV-40(34) & $8 / 15 / 91$ & $56 \pm 42$ & $137 \pm 37$ & 3.24 & $\mathrm{~N}$ \\
\hline MV-46(44) & $6 / 23 / 92$ & $137 \pm 33$ & $134 \pm 33$ & .13 & \\
\hline MV-36(60) & $7 / 29 / 92$ & $236 \pm 40$ & $268 \pm 43$ & 1.09 & \\
\hline
\end{tabular}


Table 6. Results of replicate pairs of samples from selected wells and springs, eastern Snake River Plain, analyzed for gross radioactivity and radionuclides-Continued

\begin{tabular}{|c|c|c|c|c|c|}
\hline \multirow{2}{*}{$\begin{array}{c}\text { Site } \\
\text { identifier }\end{array}$} & \multirow{2}{*}{$\begin{array}{c}\text { Date } \\
\text { sampled }\end{array}$} & \multicolumn{2}{|c|}{ Concentration } & \multirow[b]{2}{*}{ Z-value } & \multirow[b]{2}{*}{ Remark } \\
\hline & & MV & QA & & \\
\hline \multicolumn{6}{|c|}{ Radium-226, by radon emanation, NWQL (pCi/L) } \\
\hline MV-27(28) & $8 / 15 / 89$ & $0.073 \pm 0.018$ & $0.064 \pm 0.015$ & 0.77 & \\
\hline MV-7(8) & $8 / 16 / 89$ & $.112 \pm 0.024$ & $.147 \pm 0.026$ & 1.98 & $\mathrm{~N}$ \\
\hline MV-33(34) & $8 / 17 / 89$ & $.065 \pm 0.015$ & $.048 \pm 0.013$ & 1.71 & \\
\hline MV-43(44) & $8 / 22 / 89$ & $.091 \pm 0.022$ & $.069 \pm 0.019$ & 1.51 & \\
\hline$M V-61(60)$ & $9 / 14 / 89$ & $.085 \pm 0.017$ & $.096 \pm 0.019$ & .86 & \\
\hline$M V-4(8)$ & $8 / 13 / 90$ & $.058 \pm 0.018$ & $.079 \pm 0.016$ & 1.74 & \\
\hline MV-24(28) & $8 / 12 / 91$ & $.030 \pm 0.009$ & $.032 \pm 0.012$ & .27 & \\
\hline MV-40(34) & $8 / 15 / 91$ & $.027 \pm 0.011$ & $.028 \pm 0.011$ & .13 & \\
\hline MV-46(44) & $6 / 23 / 92$ & $.035 \pm 0.014$ & $.049 \pm 0.015$ & 1.36 & \\
\hline MV-36(60) & $7 / 29 / 92$ & $.024 \pm 0.008$ & $.061 \pm 0.013$ & 4.85 & $\mathrm{~N}$ \\
\hline \multicolumn{6}{|c|}{ Radium-228, by beta counter, NWQL (pCi/L) } \\
\hline MV-27(28) & $8 / 15 / 89$ & $.57 \pm 0.65$ & $.579 \pm 1.07$ & .01 & \\
\hline MV-7(8) & $8 / 16 / 89$ & $.17 \pm 0.59$ & $.03 \pm 0.62$ & .33 & \\
\hline MV-33(34) & $8 / 17 / 89$ & $.49 \pm 1.03$ & $.464 \pm 0.691$ & .04 & \\
\hline MV-43(44) & $8 / 22 / 89$ & $1.43 \pm 1.05$ & $.81 \pm 0.72$ & .97 & \\
\hline MV-61(60) & $9 / 14 / 89$ & $.618 \pm 0.623$ & $-.116 \pm 0.784$ & 1.47 & \\
\hline MV-4(8) & $8 / 13 / 90$ & $.182 \pm 0.498$ & $.071 \pm 0.460$ & .33 & \\
\hline MV-24(28) & $8 / 12 / 91$ & $.600 \pm 0.574$ & $.113 \pm 0.337$ & 1.46 & \\
\hline MV-40(34) & $8 / 15 / 91$ & $.213 \pm 0.312$ & $.265 \pm 0.304$ & .24 & \\
\hline MV-46(44) & $6 / 23 / 92$ & $.227 \pm 0.296$ & $.226 \pm 0.283$ & .00 & \\
\hline MV-36(60) & $7 / 29 / 92$ & $.100 \pm 0.275$ & $.216 \pm 0.340$ & .27 & \\
\hline \multicolumn{6}{|c|}{ Uranium, NwQL $(\mu \mathrm{g} / \mathrm{L})$} \\
\hline MV-27(28) & $8 / 15 / 89$ & $3.59 \pm 0.38$ & $3.88 \pm 0.61$ & .81 & \\
\hline MV-7(8) & $8 / 16 / 89$ & $1.78 \pm 0.33$ & $1.86 \pm 0.29$ & .36 & \\
\hline $\mathrm{MV}-33(34)$ & $8 / 17 / 89$ & $2.08 \pm 0.22$ & $1.97 \pm 0.21$ & .72 & \\
\hline$M V-43(44)$ & $8 / 22 / 89$ & $7.00 \pm 1.05$ & $6.86 \pm 0.98$ & .19 & \\
\hline$M V-61(60)$ & $9 / 14 / 89$ & $5.75 \pm 0.61$ & $2.97 \pm 0.59$ & 6.55 & $\mathbf{N}$ \\
\hline $\mathrm{MV}-4(8)$ & $8 / 13 / 90$ & $3.35 \pm 0.503$ & $3.40 \pm 0.510$ & .14 & \\
\hline MV-24(28) & $8 / 12 / 91$ & $3.35 \pm 0.503$ & $3.31 \pm 0.497$ & .11 & \\
\hline$M V-40(34)$ & $8 / 15 / 91$ & $1.48 \pm 0.221$ & $1.59 \pm 0.239$ & .68 & \\
\hline MV-46(44) & $6 / 23 / 92$ & $1.36 \pm 0.205$ & $1.65 \pm 0.247$ & 1.81 & \\
\hline MV-36(60) & $7 / 29 / 92$ & $3.16 \pm 0.474$ & $3.10 \pm 0.465$ & .18 & \\
\hline \multicolumn{6}{|c|}{ Strontium-90, NWQL (pCi/L) } \\
\hline MV-27(28) & $8 / 15 / 89$ & $.27 \pm 0.17$ & $.09 \pm 0.17$ & 1.50 & \\
\hline MV-7(8) & $8 / 16 / 89$ & $1.15 \pm 0.26$ & $.130 \pm 0.191$ & 6.32 & $\mathrm{~N}$ \\
\hline
\end{tabular}


Table 6. Results of replicate pairs of samples from selected wells and springs, eastern Snake River Plain, analyzed for gross radioactivity and radionuclides-Continued

\begin{tabular}{|c|c|c|c|c|c|}
\hline \multirow{2}{*}{$\begin{array}{c}\text { Site } \\
\text { identifier }\end{array}$} & \multirow{2}{*}{$\begin{array}{c}\text { Date } \\
\text { sampled }\end{array}$} & \multicolumn{2}{|c|}{ Concentration } & \multirow[b]{2}{*}{ Z-value } & \multirow[b]{2}{*}{ Remark } \\
\hline & & MV & QA & & \\
\hline \multicolumn{6}{|c|}{ Strontium-90, NWQL (pCi/L)-cont. } \\
\hline $\mathrm{MV}-33(34)$ & $8 / 17 / 89$ & $0.27 \pm 0.16$ & $0.16 \pm 0.17$ & 0.94 & \\
\hline$M V-43(44)$ & $8 / 22 / 89$ & $.010 \pm 0.051$ & $-.06 \pm 0.17$ & .79 & \\
\hline$M V-61(60)$ & $9 / 14 / 89$ & $2.93 \pm 0.40$ & $.06 \pm 0.18$ & 13.09 & $N$ \\
\hline $\mathrm{MV}-4(8)$ & $8 / 13 / 90$ & $.063 \pm 0.215$ & $.037 \pm 0.229$ & .17 & \\
\hline MV-24(28) & $8 / 12 / 91$ & $.055 \pm 0.195$ & $.210 \pm 0.233$ & 1.02 & \\
\hline $\mathrm{MV}-40(34)$ & $8 / 15 / 91$ & $.022 \pm 0.196$ & $.060 \pm 0.238$ & .25 & \\
\hline MV-46(44) & $6 / 23 / 92$ & $-.007 \pm 0.145$ & $.052 \pm 0.204$ & .47 & \\
\hline MV-36(60) & $7 / 29 / 92$ & $-.001 \pm 0.207$ & $.136 \pm 0.270$ & .81 & \\
\hline $\mathrm{MV}-21(8)$ & $8 / 4 / 93$ & $.049 \pm 0.201$ & $.026 \pm 0.220$ & .16 & \\
\hline $\mathrm{MV}-10(28)$ & $8 / 11 / 94$ & $.232 \pm 0.263$ & $.336 \pm 0.294$ & .53 & \\
\hline MV-56(34) & $8 / 9 / 94$ & $.280 \pm 0.276$ & $.273 \pm 0.273$ & .04 & \\
\hline MV-38(44) & $7 / 24 / 95$ & $.212 \pm 0.271$ & $.311 \pm 0.303$ & .49 & \\
\hline MV-55(60) & $7 / 26 / 95$ & $.134 \pm 0.261$ & $.238 \pm 0.255$ & .57 & \\
\hline \multicolumn{6}{|c|}{ Strontium-90, ISU (pCi/L) } \\
\hline MV-24(28) & $8 / 12 / 91$ & $0 \pm 0.2$ & $-2.7 \pm 1.0$ & 5.40 & $\mathrm{~N}$ \\
\hline$M V-46(44)$ & $6 / 23 / 92$ & $-2.3 \pm 1.4$ & $-3.9 \pm 1.0$ & 1.86 & \\
\hline MV-36(60) & $7 / 29 / 92$ & $.4 \pm 0.8$ & $-.4 \pm 1.6$ & .89 & \\
\hline \multicolumn{6}{|c|}{ Tritium, NWQL (pCi/L) } \\
\hline MV-27(28) & $8 / 15 / 89$ & $44.8 \pm 25.6$ & $64.0 \pm 25.6$ & 1.06 & \\
\hline MV-7(8) & $8 / 16 / 89$ & $-3.2 \pm 25.6$ & $3.2 \pm 25.6$ & .35 & \\
\hline MV-33(34) & $8 / 17 / 89$ & $3.2 \pm 25.6$ & $3.2 \pm 25.6$ & .00 & \\
\hline MV-43(44) & $8 / 22 / 89$ & sample lost & $73.6 \pm 25.6$ & & \\
\hline$M V-61(60)$ & $9 / 14 / 89$ & $3.2 \pm 25.6$ & $19.2 \pm 25.6$ & .88 & \\
\hline$M V-4(8)$ & $8 / 13 / 90$ & $4.67 \pm 0.57$ & $4.96 \pm 0.57$ & .72 & \\
\hline$M V-24(28)$ & $8 / 12 / 91$ & $82.6 \pm 5.76$ & $90.6 \pm 5.76$ & 1.96 & \\
\hline MV-40(34) & $8 / 15 / 91$ & $13.7 \pm 0.9$ & $14.2 \pm 0.96$ & .76 & \\
\hline MV-46(44) & $6 / 23 / 92$ & $11.8 \pm 1.02$ & $10.3 \pm 0.77$ & 2.35 & $\mathrm{~N}$ \\
\hline MV-36(60) & $7 / 29 / 92$ & $58.2 \pm 3.84$ & $60.2 \pm 3.84$ & .74 & \\
\hline MV-21(8) & $8 / 4 / 93$ & $14.2 \pm 0.96$ & $13.9 \pm 0.90$ & .46 & \\
\hline MV-10(28) & $8 / 11 / 94$ & $35.53+2.56$ & $40.96 \pm 2.56$ & 3.00 & $\mathrm{~N}$ \\
\hline MV-56(34) & $8 / 9 / 94$ & $7.81 \pm 0.576$ & $8.80 \pm 0.704$ & 2.18 & $\mathrm{~N}$ \\
\hline MV-38(44) & $7 / 24 / 95$ & $40.00 \pm 2.56$ & $37.44 \pm 2.56$ & 1.41 & \\
\hline$M V-55(60)$ & $7 / 26 / 95$ & $7.648 \pm 0.768$ & $8.064 \pm 0.832$ & .73 & \\
\hline$M V-27(28)$ & $8 / 15 / 89$ & $70 \pm 220$ & $-260 \pm 200$ & 2.12 & $\mathrm{~N}$ \\
\hline $\mathrm{MV}-7(8)$ & $8 / 16 / 89$ & $-120 \pm 220$ & $40 \pm 220$ & 1.03 & \\
\hline $\mathrm{MV}-33(34)$ & $8 / 17 / 89$ & $-210 \pm 220$ & $-70 \pm 220$ & .90 & \\
\hline
\end{tabular}


Table 6. Results of replicate pairs of samples from selected wells and springs, eastern Snake River Plain, analyzed for gross radioactivity and radionuclides-Continued

\begin{tabular}{|c|c|c|c|c|c|}
\hline \multirow{2}{*}{$\begin{array}{c}\text { Site } \\
\text { identifier }\end{array}$} & \multirow{2}{*}{$\begin{array}{c}\text { Date } \\
\text { sampled }\end{array}$} & \multicolumn{2}{|c|}{ Concentration } & \multirow[b]{2}{*}{ Z-value } & \multirow[b]{2}{*}{ Remark } \\
\hline & & MV & QA & & \\
\hline \multicolumn{6}{|c|}{ Tritium, ISU (pCi/L) } \\
\hline MV-43(44) & $8 / 22 / 89$ & $-90 \pm 220$ & $110 \pm 220$ & 1.29 & \\
\hline MV-61(60) & $9 / 14 / 89$ & $-100 \pm 220$ & $-30 \pm 220$ & .45 & \\
\hline$M V-24(28)$ & $8 / 12 / 91$ & $230 \pm 220$ & $90 \pm 220$ & .90 & \\
\hline MV-46(44) & $6 / 23 / 92$ & $260 \pm 200$ & $0 \pm 200$ & 1.84 & \\
\hline$M V-36(60)$ & $7 / 29 / 92$ & $-40 \pm 200$ & $60 \pm 200$ & .71 & \\
\hline MV-21(8) & $8 / 4 / 93$ & $-100 \pm 100$ & $-100 \pm 100$ & .00 & \\
\hline MV-10(28) & $8 / 11 / 94$ & $100 \pm 200$ & $-100 \pm 200$ & 1.41 & \\
\hline MV-56(34) & $8 / 9 / 94$ & $-300 \pm 200$ & $-100 \pm 200$ & 1.41 & \\
\hline MV-38(44) & $7 / 24 / 95$ & $40 \pm 120$ & $150 \pm 120$ & 1.30 & \\
\hline MV-55(60) & $7 / 26 / 95$ & $80 \pm 120$ & $90 \pm 120$ & .12 & \\
\hline
\end{tabular}


Table 7. Results of replicate pairs from selected wells and springs, eastern Snake River Plain, analyzed for gamma radiation

[Analyses performed by the U.S. Geological Survey National Water Quality Laboratory (NWQL) and the Idaho State University (ISU) Environmental Monitoring Laboratory. Site identifier: water-quality sample identifier followed by quality-assurance identifier in parentheses; see figure 2 for location of sites. Z-value: see section on statistical comparisons for explanation. Remark: no entry, analytical results of replicate pairs are statistically equivalent; $N$, the analytical results are not statistically equivalent; na, not analyzed. Abbreviations: pCi/L, picocurie per liter; $M V$, water-quality sample; $Q A$, quality assurance replicate sample; $\mathrm{nr}$, no result reported; naa, no analyses available]

\begin{tabular}{|c|c|c|c|c|c|}
\hline \multirow{2}{*}{$\begin{array}{c}\text { Site } \\
\text { identifier }\end{array}$} & \multirow{2}{*}{$\begin{array}{c}\text { Date } \\
\text { sampled }\end{array}$} & \multicolumn{2}{|c|}{$\begin{array}{l}\text { Concentration } \\
\qquad(\mathrm{pCi} / \mathrm{L})\end{array}$} & \multirow[b]{2}{*}{ Z-value } & \multirow[b]{2}{*}{ Remark } \\
\hline & & MV & $\mathbf{Q A}$ & & \\
\hline \multicolumn{6}{|c|}{ Potassium-40, NWQL } \\
\hline MV-27(28) & $8 / 15 / 89$ & nr & $9.43 \pm 1.94$ & & \\
\hline $\mathrm{MV}-7(8)$ & $8 / 16 / 89$ & $2.44 \pm 1.51$ & $1.39 \pm 1.39$ & 1.02 & \\
\hline MV-33(34) & $8 / 17 / 89$ & $\mathrm{nr}$ & naa & & \\
\hline MV-43(44) & $8 / 22 / 89$ & $\mathrm{nr}$ & $\mathrm{nr}$ & & \\
\hline MV-61(60) & $9 / 14 / 89$ & $5.68 \pm 1.27$ & $2.84 \pm 1.42$ & 2.98 & $N$ \\
\hline$M V-24(28)$ & $8 / 12 / 91$ & $\mathrm{nr}$ & $\mathrm{nr}$ & & \\
\hline $\mathrm{MV}-40(34)$ & $8 / 15 / 91$ & $3.27 \pm 2.47$ & $\mathrm{nr}$ & & \\
\hline MV-46(44) & $6 / 23 / 92$ & $\mathrm{nr}$ & $\mathrm{nr}$ & & \\
\hline MV-36(60) & $7 / 29 / 92$ & $1.48 \pm 2.36$ & $1.56 \pm 3.22$ & .04 & \\
\hline \multicolumn{6}{|c|}{ Cobalt-60, NWQL } \\
\hline MV-27(28) & $8 / 15 / 89$ & $\mathrm{nr}$ & $\mathrm{nr}$ & & \\
\hline $\mathrm{MV}-7(8)$ & $8 / 16 / 89$ & nr & $\mathrm{nr}$ & & \\
\hline MV-33(34) & $8 / 17 / 89$ & nr & naa & & \\
\hline$M V-43(44)$ & $8 / 22 / 89$ & $\mathrm{nr}$ & $\mathrm{nr}$ & & \\
\hline$M V-61(60)$ & $9 / 14 / 89$ & $.31 \pm 0.08$ & $\mathrm{nr}$ & & \\
\hline \multicolumn{6}{|c|}{ Cobalt-60, ISU } \\
\hline MV-21(8) & $8 / 04 / 93$ & $2.1 \pm 1.2$ & $1.1 \pm 1.2$ & .59 & \\
\hline \multicolumn{6}{|c|}{ Cesium-137, NWQL } \\
\hline $\mathrm{MV}-4(8)$ & $8 / 13 / 90$ & $\mathrm{nr}$ & $.013 \pm 0.103$ & & \\
\hline$M V-24(28)$ & $8 / 12 / 91$ & $.057 \pm 0.115$ & $-.039 \pm 0.096$ & 1.28 & \\
\hline MV-40(34) & $8 / 15 / 91$ & $.014 \pm 0.097$ & $-.063 \pm 0.094$ & 1.14 & \\
\hline$M V-46(44)$ & $6 / 23 / 92$ & $.007 \pm 0.087$ & $.014 \pm 0.090$ & .11 & \\
\hline$M V-36(60)$ & $7 / 29 / 92$ & $.031 \pm 0.096$ & $-.051 \pm 0.092$ & 1.24 & \\
\hline \multicolumn{6}{|c|}{ Cesium-137, ISU } \\
\hline$M V-24(28)$ & $8 / 12 / 91$ & $1 \pm 2$ & $3 \pm 2$ & 1.41 & \\
\hline$M V-40(34)$ & $8 / 15 / 91$ & $1 \pm 2$ & naa & $=$ & \\
\hline MV-46(44) & $6 / 23 / 92$ & $.3 \pm 2.2$ & $.4 \pm 2.4$ & .06 & \\
\hline MV-36(60) & $7 / 29 / 92$ & $.5 \pm 2.2$ & $.2 \pm 1.8$ & .21 & \\
\hline MV-21(8) & $8 / 04 / 93$ & $-1.1 \pm 1.2$ & $1.0 \pm 1.2$ & 1.24 & \\
\hline MV-10(28) & $8 / 11 / 94$ & $2.0 \pm 2.8$ & $-4.2 \pm 2.7$ & 3.19 & $\mathrm{~N}$ \\
\hline MV-56(34) & $8 / 09 / 94$ & $0 \pm 2.6$ & $1.0 \pm 2.7$ & .53 & \\
\hline$M V-38(44)$ & $7 / 24 / 95$ & $2.45 \pm 3.94$ & $2.43 \pm 2.18$ & .01 & \\
\hline MV-55(60) & $7 / 26 / 95$ & $2.36 \pm 3.74$ & $-.44 \pm 2.00$ & 1.32 & \\
\hline
\end{tabular}


Table 7. Results of replicate pairs from selected wells and springs, eastern Snake River Plain, analyzed for gamma radiation-Continued

\begin{tabular}{|c|c|c|c|c|c|}
\hline \multirow{2}{*}{$\begin{array}{c}\text { Site } \\
\text { identifier }\end{array}$} & \multirow{2}{*}{$\begin{array}{c}\text { Date } \\
\text { sampled }\end{array}$} & \multicolumn{2}{|c|}{$\begin{array}{c}\text { Concentration } \\
(\mathrm{pCi} / \mathrm{L})\end{array}$} & \multirow[b]{2}{*}{ Z-value } & \multirow[b]{2}{*}{ Remark } \\
\hline & & MV & QA & & \\
\hline \multicolumn{6}{|c|}{ Lead-212, NWQL } \\
\hline $\mathrm{MV}-7(8)$ & $8 / 16 / 89$ & $0.204 \pm 0.101$ & $0.806 \pm 0.137$ & 7.07 & $\mathrm{~N}$ \\
\hline $\mathrm{MV}-27(28)$ & $8 / 15 / 89$ & $\mathrm{nr}$ & $.683 \pm 0.166$ & & \\
\hline MV-33(34) & $8 / 17 / 89$ & $\mathrm{nr}$ & naa & & \\
\hline$M V-43(44)$ & $8 / 22 / 89$ & $.754 \pm 0.441$ & $\mathrm{nr}$ & & \\
\hline$M V-61(60)$ & $9 / 14 / 89$ & nr & $\mathrm{nr}$ & & \\
\hline MV-4(8) & $8 / 13 / 90$ & $\mathrm{nr}$ & $\mathrm{nr}$ & & \\
\hline MV-24(28) & $8 / 12 / 91$ & $.227 \pm 0.133$ & $\mathrm{nr}$ & & \\
\hline $\mathrm{MV}-40(34)$ & $8 / 15 / 91$ & $\mathrm{nr}$ & $\mathrm{nr}$ & & \\
\hline \multicolumn{6}{|c|}{ Lead-214, NWQL } \\
\hline $\mathrm{MV}-4(8)$ & $8 / 13 / 90$ & $.318 \pm 0.244$ & $\mathrm{nr}$ & & \\
\hline $\mathrm{MV}-24(28)$ & $8 / 12 / 91$ & $\mathrm{nr}$ & $\mathrm{nr}$ & & \\
\hline MV-40(34) & $8 / 15 / 91$ & nr & $\mathrm{nr}$ & & \\
\hline \multicolumn{6}{|c|}{ Bismuth-212, NWQL } \\
\hline$M V-27(28)$ & $8 / 15 / 89$ & $\mathrm{nr}$ & $\mathrm{nr}$ & & \\
\hline MV-7(8) & $8 / 16 / 89$ & $\mathrm{nr}$ & $\mathrm{nr}$ & & \\
\hline MV-33(34) & $8 / 17 / 89$ & $\mathrm{nr}$ & naa & & \\
\hline $\mathrm{MV}-43(44)$ & $8 / 22 / 89$ & $\mathrm{nr}$ & $\mathrm{nr}$ & & \\
\hline MV-61(60) & $9 / 14 / 89$ & $\mathrm{nr}$ & $\mathrm{nr}$ & & \\
\hline $\mathrm{MV}-4(8)$ & $8 / 13 / 90$ & $\mathrm{nr}$ & $\mathrm{nr}$ & & \\
\hline \multicolumn{6}{|c|}{ Bismuth-214, NWQL } \\
\hline $\mathrm{MV}-4(8)$ & $8 / 13 / 90$ & $\mathrm{nr}$ & $\mathrm{nr}$ & & \\
\hline MV-24(28) & $8 / 12 / 91$ & $\mathrm{nr}$ & $\mathrm{nr}$ & & \\
\hline MV-40(34) & $8 / 15 / 91$ & $\mathrm{nr}$ & $\mathrm{nr}$ & & \\
\hline \multicolumn{6}{|c|}{ Radium-224, NWQL } \\
\hline $\mathrm{MV}-27(28)$ & $8 / 15 / 89$ & $.722 \pm 0.089$ & $.828 \pm 0.202$ & .96 & \\
\hline MV-7(8) & $8 / 16 / 89$ & $.245 \pm 0.122$ & $.965 \pm 0.164$ & 7.04 & $\mathrm{~N}$ \\
\hline $\mathrm{MV}-33(34)$ & $8 / 17 / 89$ & $.722 \pm 0.202$ & naa & & \\
\hline$M V-43(44)$ & $8 / 22 / 89$ & $.875 \pm 0.511$ & $.237 \pm 0.110$ & 2.44 & $\mathrm{~N}$ \\
\hline$M V-61(60)$ & $9 / 14 / 89$ & $.91 \pm 0.18$ & $.284 \pm 0.112$ & 5.91 & $N$ \\
\hline \multicolumn{6}{|c|}{ Radium-226, NWQL } \\
\hline$M V-27(28)$ & $8 / 15 / 89$ & $\mathrm{nr}$ & $\mathrm{nr}$ & & \\
\hline MV-7(8) & $8 / 16 / 89$ & $n r$ & $\mathrm{nr}$ & & \\
\hline $\mathrm{MV}-33(34)$ & $8 / 17 / 89$ & nr & naa & & \\
\hline$M V-43(44)$ & $8 / 22 / 89$ & $\mathrm{nr}$ & $\mathrm{nr}$ & & \\
\hline$M V-61(60)$ & $9 / 14 / 89$ & $.39 \pm 0.14$ & $\mathrm{nr}$ & & \\
\hline MV-46(44) & $6 / 23 / 92$ & $.351 \pm 0.196$ & $.317 \pm 0.200$ & .24 & \\
\hline $\mathrm{MV}-36(60)$ & $7 / 29 / 92$ & nr & nr & & \\
\hline
\end{tabular}


Table 7. Results of replicate pairs from selected wells and springs, eastern Snake River Plain, analyzed for gamma radiation-Continued

\begin{tabular}{|c|c|c|c|c|c|}
\hline \multirow{2}{*}{$\begin{array}{c}\text { Site } \\
\text { identifier }\end{array}$} & \multirow{2}{*}{$\begin{array}{l}\text { Date } \\
\text { sampled }\end{array}$} & \multicolumn{2}{|c|}{$\begin{array}{c}\text { Concentration } \\
(\mathrm{pCi} / \mathrm{L})\end{array}$} & \multirow[b]{2}{*}{ Z-value } & \multirow[b]{2}{*}{ Remark } \\
\hline & & MV & QA & & \\
\hline \multicolumn{6}{|c|}{ Radium-228, NWQL } \\
\hline MV-27(28) & $8 / 15 / 89$ & $\mathrm{nr}$ & $0.571 \pm 0.369$ & & \\
\hline MV-7(8) & $8 / 16 / 89$ & $.457 \pm 0.259$ & $\mathrm{nr}$ & & \\
\hline MV-33(34) & $8 / 17 / 89$ & $\mathrm{nr}$ & naa & & \\
\hline$M V-43(44)$ & $8 / 22 / 89$ & $\mathrm{nr}$ & $\mathrm{nr}$ & & \\
\hline MV-61(60) & $9 / 14 / 89$ & $\mathrm{nr}$ & $.393 \pm 0.233$ & & \\
\hline \multicolumn{6}{|c|}{ Thorium-234, NWQL } \\
\hline MV-27(28) & $8 / 15 / 89$ & $\mathrm{nr}$ & $10.06 \pm 1.13$ & & \\
\hline $\mathrm{MV}-7(8)$ & $8 / 16 / 89$ & $4.09 \pm 1.09$ & $3.72 \pm 0.94$ & .51 & \\
\hline MV-33(34) & $8 / 17 / 89$ & $9.52 \pm 1.15$ & naa & & \\
\hline$M V-43(44)$ & $8 / 22 / 89$ & $\mathrm{nr}$ & $1.92 \pm 0.52$ & & \\
\hline MV-61(60) & $9 / 14 / 89$ & $\mathrm{nr}$ & $3.38 \pm 0.96$ & & \\
\hline \multicolumn{6}{|c|}{ Uranium-235, NWQL } \\
\hline MV-46(44) & $6 / 23 / 92$ & $\mathrm{nr}$ & $\mathrm{nr}$ & & \\
\hline MV-36(60) & $7 / 29 / 92$ & $\mathrm{nr}$ & $\mathrm{nr}$ & & \\
\hline \multicolumn{4}{|c|}{ Uranium-238, NWQL } & & \\
\hline MV-46(44) & $6 / 23 / 92$ & $\mathrm{nr}$ & $\mathrm{nr}$ & & \\
\hline MV-36(60) & $7 / 29 / 92$ & $\mathrm{nr}$ & $.497 \pm 0.175$ & & \\
\hline
\end{tabular}


Table 8. Results of replicate pairs of samples from selected wells and springs, eastern Snake River Plain, analyzed for organic carbon and anionic surfactants as methylene blue active substances

[Analyses performed by the U.S. Geological Survey National Water Quality Laboratory. Site identifier: water-quality sample identifier followed by quality-assurance identifier in parentheses; see figure 2 for location of sites. Z-value: see section on statistical comparisons for explanation. Remark: no entry, analytical results of replicate pairs are statistically equivalent; $N$, the analytical results are not statistically equivalent. Abbreviations: $\mathrm{mg} / \mathrm{L}$, milligram per liter; $\mathrm{MV}$, water-quality sample; $Q A$, quality-assurance replicate sample; WWR, whole water, recoverable. Symbol: <, the result was less than the indicated reporting level]

\begin{tabular}{|c|c|c|c|c|c|}
\hline \multirow[b]{2}{*}{ Site identifier } & \multirow[b]{2}{*}{ Date sampled } & \multicolumn{2}{|c|}{$\begin{array}{c}\text { Concentration } \\
(\mathrm{mg} / \mathrm{L})\end{array}$} & \multirow[b]{2}{*}{ Z-value } & \multirow[b]{2}{*}{ Remark } \\
\hline & & MV & QA & & \\
\hline \multicolumn{6}{|c|}{ Dissolved organic carbon } \\
\hline$M V-61(60)$ & $9 / 14 / 89$ & 0.4 & 0.5 & 0.48 & \\
\hline$M V-4(8)$ & $8 / 13 / 90$ & 1.1 & 1.2 & .49 & \\
\hline MV-24(28) & $8 / 12 / 91$ & 2.3 & 2.4 & .50 & \\
\hline MV-40(34) & $8 / 15 / 91$ & .5 & .4 & .48 & \\
\hline MV-46(44) & $6 / 23 / 92$ & .2 & .2 & .00 & \\
\hline $\mathrm{MV}-36(60)$ & $7 / 29 / 92$ & .6 & .5 & .48 & \\
\hline$M V-21(8)$ & $8 / 4 / 93$ & .3 & 1.2 & 4.37 & $\mathrm{~N}$ \\
\hline$M V-10(28)$ & $8 / 11 / 94$ & .9 & .9 & .00 & \\
\hline MV-56(34) & $8 / 9 / 94$ & .4 & .4 & .00 & \\
\hline MV-38(44) & $7 / 24 / 95$ & .3 & .3 & .00 & \\
\hline MV-55(60) & $7 / 26 / 95$ & .3 & .4 & .48 & \\
\hline \multicolumn{6}{|c|}{ WWR anionic surfactants as methylene blue active substances } \\
\hline MV-27(28) & $8 / 15 / 89$ & .05 & .05 & .00 & \\
\hline $\mathrm{MV}-7(8)$ & $8 / 16 / 89$ & .01 & .02 & 4.47 & $\mathrm{~N}$ \\
\hline MV-33(34) & $8 / 17 / 89$ & .01 & .01 & .00 & \\
\hline $\mathrm{MV}-43(44)$ & $8 / 22 / 89$ & $: 08$ & .09 & .83 & \\
\hline$M V-61(60)$ & $9 / 14 / 89$ & $<.01$ & .02 & 4.47 & $\mathrm{~N}$ \\
\hline MV-4(8) & $8 / 13 / 90$ & .04 & .04 & .00 & \\
\hline MV-24(28) & $8 / 12 / 91$ & .07 & .08 & .94 & \\
\hline MV-40(34) & $8 / 15 / 91$ & $<.01$ & $<.01$ & 0 & \\
\hline $\mathrm{MV}-46(44)$ & $6 / 23 / 92$ & $<.01$ & $<.01$ & 0 & \\
\hline$M V-36(60)$ & $7 / 29 / 92$ & .02 & .02 & .00 & \\
\hline$M V-21(8)$ & $8 / 4 / 93$ & .01 & .01 & .00 & \\
\hline MV-10(28) & $8 / 11 / 94$ & $<.02$ & $<.02$ & 0 & \\
\hline MV-56(34) & $8 / 9 / 94$ & $<.02$ & $<.02$ & 0 & \\
\hline MV-38(44) & $7 / 24 / 95$ & $<.02$ & $<.02$ & 0 & \\
\hline$M V-55(60)$ & $7 / 26 / 95$ & $<.02$ & $<.02$ & 0 & \\
\hline
\end{tabular}


Table 9. Results of replicate pairs of samples from selected wells and springs, eastern Snake River Plain, analyzed for volatile organic compounds

[Analyses performed by the U.S. Geological Survey National Water Quality Laboratory. Site identifier: water-quality identifier followed by quality-assurance identifier in

parentheses; see figure 2 for location of sites. Z-value: see section on statistical comparisons for explanation. Remark: no entry, analytical results of replicate pairs are statistically

equivalent; $\mathrm{N}$, the analytical results are not statistically equivalent. Abbreviations: $\mu \mathrm{g} / \mathrm{L}$, microgram per liter; MV, water-quality sample; QA, quality-assurance replicate sample. Symbol: $<$, the result was less than the stated value. Numbers in bold indicate the results were at or above their respective reporting limits]

\begin{tabular}{|c|c|c|c|c|c|c|c|c|c|c|c|c|c|}
\hline \multirow{2}{*}{$\begin{array}{c}\text { Site } \\
\text { Identifier }\end{array}$} & \multirow{2}{*}{$\begin{array}{c}\text { Date } \\
\text { sampled }\end{array}$} & \multicolumn{2}{|c|}{$\begin{array}{c}\text { Concentration } \\
(\mu \mathrm{g} / \mathrm{L})\end{array}$} & \multirow[b]{2}{*}{ Z-value } & \multirow[b]{2}{*}{ Remark } & \multicolumn{2}{|c|}{$\begin{array}{c}\text { Concentration } \\
(\mu g / L)\end{array}$} & \multirow[b]{2}{*}{ Z-value } & \multirow[b]{2}{*}{ Remark } & \multicolumn{2}{|c|}{$\begin{array}{c}\text { Concentration } \\
(\mu \mathrm{g} / \mathrm{L})\end{array}$} & \multirow[b]{2}{*}{ Z-value } & \multirow[b]{2}{*}{ Remark } \\
\hline & & MV & $\mathbf{Q A}$ & & & MV & $\mathbf{Q A}$ & & & MV & $\mathbf{Q A}$ & & \\
\hline & & \multicolumn{4}{|c|}{ Benzene } & \multicolumn{4}{|c|}{ Ethylbenzene } & \multicolumn{4}{|c|}{ n-Propylbenzene } \\
\hline MV-27(28) & $8 / 15 / 89$ & $<0.2$ & $<0.2$ & 0 & & $<0.2$ & $<0.2$ & 0 & & $<0.2$ & $<0.2$ & 0 & \\
\hline $\mathrm{MV}-7(8)$ & $8 / 16 / 89$ & $<.2$ & $<.2$ & 0 & & $<.2$ & $<.2$ & 0 & & $<.2$ & $<.2$ & 0 & \\
\hline MV-33(34) & $8 / 17 / 89$ & $<.2$ & $<.2$ & 0 & & $<.2$ & $<.2$ & 0 & & $<.2$ & $<.2$ & 0 & \\
\hline$M V-43(44)$ & $8 / 22 / 89$ & $<.2$ & $<.2$ & 0 & & $<.2$ & $<.2$ & 0 & & $<.2$ & $<.2$ & 0 & \\
\hline$M V-61(60)$ & $9 / 14 / 89$ & $<.2$ & $<.2$ & 0 & & $<.2$ & $<.2$ & 0 & & $<.2$ & $<.2$ & 0 & \\
\hline$M V-4(8)$ & $8 / 13 / 90$ & $<.2$ & $<.2$ & 0 & & $<.2$ & $<.2$ & 0 & & $<.2$ & $<.2$ & 0 & \\
\hline MV-24(28) & $8 / 12 / 91$ & $<.2$ & $<.2$ & 0 & & $<.2$ & $<.2$ & 0 & & $<.2$ & $<.2$ & 0 & \\
\hline MV $-40(34)$ & $8 / 15 / 91$ & $<.2$ & $<.2$ & 0 & & $<.2$ & $<.2$ & 0 & & $<.2$ & $<.2$ & 0 & \\
\hline$M V-46(44)$ & $6 / 23 / 92$ & $<.2$ & $<.2$ & 0 & & $<.2$ & $<.2$ & 0 & & $<.2$ & $<.2$ & 0 & \\
\hline$M V-36(60)$ & $7 / 29 / 92$ & $<.2$ & $<.2$ & 0 & & $<.2$ & $<.2$ & $\mathbf{0}$ & & $<.2$ & $<.2$ & 0 & \\
\hline MV-21(8) & $8 / 4 / 93$ & $<.2$ & $<.2$ & 0 & & $<.2$ & $<.2$ & 0 & & $<.2$ & $<.2$ & 0 & \\
\hline MV-10(28) & $8 / 11 / 94$ & $<.2$ & $<.2$ & 0 & & $<.2$ & $<.2$ & 0 & & $<.2$ & $<.2$ & 0 & \\
\hline$M V-56(34)$ & $8 / 9 / 94$ & $<.2$ & $<.2$ & 0 & & $<.2$ & $<.2$ & 0 & & $<.2$ & $<.2$ & 0 & \\
\hline MV-38(44) & $7 / 24 / 95$ & $<.2$ & $<.2$ & 0 & & $<.2$ & $<.2$ & 0 & & $<.2$ & $<.2$ & 0 & \\
\hline$M V-55(60)$ & $7 / 26 / 95$ & $<.2$ & $<.2$ & 0 & & $<.2$ & $<.2$ & 0 & & $<.2$ & $<.2$ & 0 & \\
\hline & & \multicolumn{4}{|c|}{ 1,1,1-Trichloroethane } & \multicolumn{4}{|c|}{ 1,2,4-Trimethylbenzene } & \multicolumn{4}{|c|}{ 1,3,5-Trimethylbenzene } \\
\hline $\mathrm{MV}-27(28)$ & $8 / 15 / 89$ & $<.2$ & $<.2$ & 0 & & $<.2$ & $<.2$ & 0 & & $<.2$ & $<.2$ & 0 & \\
\hline$M V-7(8)$ & $8 / 16 / 89$ & $<.2$ & $<.2$ & 0 & & $<.2$ & $<.2$ & 0 & & $<.2$ & $<.2$ & 0 & \\
\hline MV-33(34) & $8 / 17 / 89$ & $<.2$ & $<.2$ & 0 & & 1.0 & .7 & 1.76 & & .4 & .2 & 3.44 & $\mathrm{~N}$ \\
\hline MV-43(44) & $8 / 22 / 89$ & $<.2$ & $<.2$ & 0 & & $<.2$ & $<.2$ & 0 & & $<.2$ & $<.2$ & 0 & \\
\hline MV $-61(60)$ & $9 / 14 / 89$ & $<.2$ & $<.2$ & 0 & & $<.2$ & $<.2$ & 0 & & $<.2$ & $<.2$ & 0 & \\
\hline$M V-4(8)$ & $8 / 13 / 90$ & $<.2$ & $<.2$ & 0 & & $<.2$ & $<.2$ & 0 & & $<.2$ & $<.2$ & 0 & \\
\hline MV-36(60) & $7 / 29 / 92$ & $<.2$ & $<.2$ & 0 & & $<.2$ & $<.2$ & 0 & & $<.2$ & $<.2$ & 0 & \\
\hline
\end{tabular}


Table 9. Results of replicate pairs of samples from selected wells and springs, eastern Snake River Plain, analyzed for volatile organic compounds-Continued

\begin{tabular}{|c|c|c|c|c|c|c|c|c|c|c|c|c|c|}
\hline \multirow{2}{*}{$\begin{array}{c}\text { Site } \\
\text { Identifier }\end{array}$} & \multirow{2}{*}{$\begin{array}{l}\text { Date } \\
\text { sampled }\end{array}$} & \multicolumn{2}{|c|}{$\begin{array}{c}\text { Concentration } \\
(\mu \mathrm{g} / \mathrm{L})\end{array}$} & \multirow[b]{2}{*}{ Z-value } & \multirow[b]{2}{*}{ Remark } & \multicolumn{2}{|c|}{$\begin{array}{c}\text { Concentration } \\
(\mu \mathrm{g} / \mathrm{L})\end{array}$} & \multirow[b]{2}{*}{ Z-value } & \multirow[b]{2}{*}{ Remark } & \multicolumn{2}{|c|}{$\begin{array}{c}\text { Concentration } \\
(\mu \mathrm{g} / \mathrm{L})\end{array}$} & \multirow[b]{2}{*}{ Z-value } & \multirow[b]{2}{*}{ Remark } \\
\hline & & MV & QA & & & MV & QA & & & MV & QA & & \\
\hline & & \multicolumn{4}{|c|}{ 1,1,1-Trichloroethane-cont. } & \multicolumn{4}{|c|}{ 1,2,4-Trimethylbenzene-cont. } & \multicolumn{4}{|c|}{ 1,3,5-Trimethylbenzene-cont. } \\
\hline$M V-21(8)$ & $8 / 4 / 93$ & $<0.2$ & $<0.2$ & 0 & & $<.02$ & $<0.2$ & 0 & & $<0.2$ & $<0.2$ & 0 & \\
\hline MV-10(28) & $8 / 11 / 94$ & $<.2$ & $<.2$ & 0 & & $<.2$ & $<.2$ & 0 & & $<.2$ & $<.2$ & 0 & \\
\hline MV-56(34) & $8 / 9 / 94$ & $<.2$ & $<.2$ & 0 & & $<.2$ & $<.2$ & 0 & & $<.2$ & $<.2$ & 0 & \\
\hline MV-38(44) & $7 / 24 / 95$ & $<.2$ & $<.2$ & 0 & & $<.2$ & $<.2$ & 0 & & $<.2$ & $<.2$ & 0 & \\
\hline \multirow[t]{2}{*}{ MV-55(60) } & $7 / 26 / 95$ & $<.2$ & $<.2$ & 0 & & $<.2$ & $<.2$ & 0 & & $<.2$ & $<.2$ & 0 & \\
\hline & \multicolumn{5}{|c|}{ Toluene } & \multicolumn{4}{|c|}{ Xylene } & & & & \\
\hline$M V-27(28)$ & $8 / 15 / 89$ & $<.2$ & $<.2$ & 0 & & $<.2$ & $<.2$ & 0 & & & & & \\
\hline MV-7(8) & $8 / 16 / 89$ & $<.2$ & $<.2$ & 0 & & $<.2$ & $<.2$ & 0 & & & & & \\
\hline MV-33(34) & $8 / 17 / 89$ & $<.2$ & $<.2$ & 0 & & .2 & .4 & 4.07 & $\mathrm{~N}$ & & & & \\
\hline MV-43(44) & $8 / 22 / 89$ & $<.2$ & $<.2$ & 0 & & .4 & .4 & .00 & & & & & \\
\hline MV-61(60) & $9 / 14 / 89$ & 1.0 & .9 & .68 & & $<.2$ & $<.2$ & 0 & & & & & \\
\hline MV-4(8) & $8 / 13 / 90$ & $<.2$ & $<.2$ & 0 & & $<.2$ & $<.2$ & 0 & & & & & \\
\hline MV-24(28) & $8 / 12 / 91$ & $<.2$ & $<.2$ & 0 & & $<.2$ & $<.2$ & 0 & & & & & \\
\hline MV-40(34) & $8 / 15 / 91$ & $<.2$ & $<.2$ & 0 & & $<.2$ & $<.2$ & 0 & & & & & \\
\hline MV-46(44) & $6 / 23 / 92$ & $<.2$ & $<.2$ & 0 & & $<.2$ & $<.2$ & 0 & & & & & \\
\hline MV-36(60) & $7 / 29 / 92$ & $<.2$ & $<.2$ & 0 & & $<.2$ & $<.2$ & 0 & & & & & \\
\hline$M V-21(8)$ & $8 / 4 / 93$ & $<.2$ & $<.2$ & 0 & & $<.2$ & $<.2$ & 0 & & & & & \\
\hline MV-10(28) & $8 / 11 / 94$ & $<.2$ & $<.2$ & 0 & & $<.2$ & $<.2$ & 0 & & & & & \\
\hline MV-56(34) & $8 / 9 / 94$ & $<.2$ & $<.2$ & 0 & & $<.2$ & $<.2$ & 0 & & & & & \\
\hline MV-38(44) & $7 / 24 / 95$ & $<.2$ & $<.2$ & 0 & & $<.2$ & $<.2$ & 0 & & & & & \\
\hline MV-55(60) & $7 / 26 / 95$ & $<.2$ & $<.2$ & 0 & & $<.2$ & $<.2$ & 0 & & & & & \\
\hline
\end{tabular}


Table 10. Results of replicate pairs of samples from selected wells and springs, eastern Snake River Plaln, analyzed for pesticides

[Analyses performed by the U.S. Geological Survey National Water Quality Laboratory. Site identifier: water-quality sample identifier followed by quality-assurance identifier in parentheses; see figure 2 for location of sites. Z-value: see section on statistical comparisons for explanation. Remark: no entry, analytical results of replicate pairs are statistically equivalent; I, statistical equivalence of the analytical results of the replicate pairs is indeterminate. Abbreviation: $\mu \mathrm{g} / \mathrm{L}$, microgram per liter; MV, water-quality sample; QA, quality assurance replicate sample. Symbol: $<$, the result was less than the indicated reporting level]

\begin{tabular}{|c|c|c|c|c|c|c|c|c|c|c|c|c|c|}
\hline \multirow{2}{*}{$\begin{array}{c}\text { Site } \\
\text { identifier }\end{array}$} & \multirow{2}{*}{$\begin{array}{c}\text { Date } \\
\text { sampled }\end{array}$} & \multicolumn{2}{|c|}{$\begin{array}{c}\text { Concentration } \\
(\mu \mathrm{g} / \mathbf{L})\end{array}$} & \multirow[b]{2}{*}{$Z$-value } & \multirow[b]{2}{*}{ Remark } & \multicolumn{2}{|c|}{$\begin{array}{c}\text { Concentration } \\
(\mu \mathrm{g} / \mathrm{L})\end{array}$} & \multirow[b]{2}{*}{$Z$-value } & \multirow[b]{2}{*}{ Remark } & \multicolumn{2}{|c|}{$\begin{array}{c}\text { Concentration } \\
(\mu \mathrm{g} / \mathbf{L})\end{array}$} & \multirow[b]{2}{*}{ Z-value } & \multirow[b]{2}{*}{ Remark } \\
\hline & & MV & QA & & & MV & $\mathbf{Q A}$ & & & MV & QA & & \\
\hline \multicolumn{14}{|c|}{ Herbicides } \\
\hline & & \multicolumn{4}{|c|}{ Atrazine } & \multicolumn{3}{|c|}{ 2,4-D } & & \multirow{2}{*}{\multicolumn{3}{|c|}{ Desethylatrazine }} & \\
\hline$M V-27(28)$ & $8 / 15 / 89$ & $<0.1$ & $<0.1$ & 0 & & $<0.01$ & $<0.01$ & 0 & & & & & \\
\hline$M V-7(8)$ & $8 / 16 / 89$ & $<.1$ & $<.1$ & 0 & & $<.01$ & $<.01$ & 0 & & & & & \\
\hline MV-33(34) & $8 / 17 / 89$ & $<.1$ & $<.1$ & 0 & & $<.01$ & $<.01$ & 0 & & & & & \\
\hline MV-43(44) & $8 / 22 / 89$ & $<.1$ & $<.1$ & 0 & & $<.01$ & $<.01$ & 0 & & & & & \\
\hline MV-6I(60) & $9 / 14 / 89$ & $<.1$ & $<.1$ & 0 & & $<.01$ & $<.01$ & 0 & & & & & \\
\hline MV-4(8) & $8 / 13 / 90$ & $<.1$ & $<.1$ & 0 & & $<.01$ & $<.01$ & 0 & & & & & \\
\hline$M V-24(28)$ & $8 / 12 / 91$ & $<.1$ & $<.1$ & 0 & & $<.01$ & $<.01$ & 0 & & & & & \\
\hline$M V-40(34)$ & $8 / 15 / 91$ & $<.1$ & $<.1$ & 0 & & $<.01$ & $<.01$ & 0 & & & & & \\
\hline MV-46(44) & $6 / 23 / 92$ & $<.1$ & $<.1$ & 0 & & $<.01$ & $<.01$ & 0 & & & & & \\
\hline MV-36(60) & $7 / 29 / 92$ & $<.1$ & $<.1$ & 0 & & $<.01$ & $<.01$ & 0 & & & & & \\
\hline MV-21(8) & $8 / 4 / 93$ & $<.1$ & $<.1$ & 0 & & $<.01$ & $<.01$ & 0 & & & & & \\
\hline$M V-10(28)$ & $8 / 11 / 94$ & $.003^{1}$ & $.005^{1}$ & & I & $<.01$ & $<.01$ & 0 & & $0.002^{1}$ & $<0.005$ & & 1 \\
\hline MV-56(34) & $8 / 9 / 94$ & $<.017$ & $<.017$ & 0 & & $<.01$ & $<.01$ & 0 & & $<.005$ & $<.005$ & 0 & \\
\hline MV-38(44) & $7 / 24 / 95$ & $<.017$ & $.004^{1}$ & & I & $<.01$ & $<.01$ & 0 & & $<.005$ & .005 & & I \\
\hline \multirow[t]{2}{*}{ MV-55(60) } & $7 / 26 / 95$ & $<.017$ & $<.017$ & 0 & & $<.01$ & $<.01$ & 0 & & $<.005$ & $<.005$ & 0 & \\
\hline & & \multicolumn{4}{|c|}{ EPTC } & \multicolumn{4}{|c|}{ Metribuzin } & \multicolumn{4}{|c|}{ Pebulate } \\
\hline MV-27(28) & $8 / 15 / 89$ & & & & & $<.1$ & $<.1$ & 0 & & & & & \\
\hline MV-7(8) & $8 / 16 / 89$ & & & & & $<.1$ & $<.1$ & 0 & & & & & \\
\hline MV-33(34) & $8 / 17 / 89$ & & & & & $<.1$ & $<.1$ & 0 & & & & & \\
\hline MV-43(44) & $8 / 22 / 89$ & & & & & $<.1$ & $<.1$ & 0 & & & & & \\
\hline MV-61(60) & $9 / 14 / 89$ & & & & & $<.1$ & $<.1$ & 0 & & & & & \\
\hline MV-4(8) & $8 / 13 / 90$ & & & & & $<.1$ & $<.1$ & 0 & & & & & \\
\hline MV-24(28) & $8 / 12 / 91$ & & & & & $<.1$ & $<.1$ & 0 & & & & & \\
\hline
\end{tabular}


Table 10. Results of replicate pairs of samples from selected wells and springs, eastern Snake River Plain, analyzed for pesticides-Continued

\begin{tabular}{|c|c|c|c|c|c|c|c|c|c|c|c|c|c|}
\hline \multirow{2}{*}{$\begin{array}{c}\text { Site } \\
\text { identifier }\end{array}$} & \multirow{2}{*}{$\begin{array}{l}\text { Date } \\
\text { sampled }\end{array}$} & \multicolumn{2}{|c|}{$\begin{array}{c}\text { Concentration } \\
(\mu \mathrm{g} / \mathrm{L})\end{array}$} & \multirow[b]{2}{*}{ Z-value } & \multirow[b]{2}{*}{ Remark } & \multicolumn{2}{|c|}{$\begin{array}{l}\text { Concentration } \\
(\mu \mathrm{g} / \mathrm{L})\end{array}$} & \multirow[b]{2}{*}{ Z-value } & \multirow[b]{2}{*}{ Remark } & \multicolumn{2}{|c|}{$\begin{array}{c}\text { Concentration } \\
(\mu \mathrm{g} / \mathrm{L})\end{array}$} & \multirow[b]{2}{*}{ Z-value } & \multirow[b]{2}{*}{ Remark } \\
\hline & & MV & QA & & & MV & QA & & & MV & QA & & \\
\hline \multicolumn{14}{|c|}{ Herbicides-cont. } \\
\hline & & \multicolumn{4}{|c|}{ EPTC-cont. } & \multicolumn{4}{|c|}{ Metribuzin-cont. } & \multicolumn{4}{|c|}{ Pebulate-cont. } \\
\hline MV-40(34) & $8 / 15 / 91$ & & & & & $<0.1$ & $<0.1$ & 0 & & & & & \\
\hline MV-46(44) & $6 / 23 / 92$ & & & & & $<.1$ & $<.1$ & 0 & & & & & \\
\hline MV-36(60) & $7 / 29 / 92$ & & & & & & & & & & & & \\
\hline$M V-21(8)$ & $8 / 4 / 93$ & & & & & & & & & & & & \\
\hline MV-10(28) & $811 / 94$ & $<0.005$ & $<0.005$ & 0 & & $<.012$ & $<.012$ & 0 & & $<0.009$ & $<0.009$ & 0 & \\
\hline MV-56(34) & $8 / 9 / 94$ & $<.005$ & $<.005$ & 0 & & $<.012$ & $<.012$ & 0 & & $<.009$ & $<.009$ & 0 & \\
\hline MV-38(44) & $7 / 24 / 95$ & $<.005$ & $<.005$ & 0 & & $<.012$ & $<.012$ & 0 & & $<.009$ & $<.009$ & 0 & \\
\hline MV-55(60) & $7 / 26 / 95$ & $<.005$ & $<.005$ & 0 & & $<.012$ & $<.012$ & 0 & & $<.009$ & $<.009$ & 0 & \\
\hline \multicolumn{14}{|c|}{ Simazine } \\
\hline$M V-27(28)$ & $8 / 15 / 89$ & $<.1$ & $<.1$ & 0 & & & & & & & & & \\
\hline MV-7(8) & $8 / 16 / 89$ & $<.1$ & $<.1$ & 0 & & & & & & & & & \\
\hline MV-33(34) & $8 / 17 / 89$ & $<.1$ & $<.1$ & 0 & & & & & & & & & \\
\hline MV-43(44) & $8 / 22 / 89$ & $<.1$ & $<.1$ & 0 & & & & & & & & & \\
\hline MV-61(60) & $9 / 14 / 89$ & $<.1$ & $<.1$ & 0 & & & & & & & & & \\
\hline$M V-4(8)$ & $8 / 13 / 90$ & $<.1$ & $<.1$ & 0 & & & & & & & & & \\
\hline$M V-24(28)$ & $8 / 12 / 91$ & $<.1$ & $<.1$ & 0 & & & & & & & & & \\
\hline MV-40(34) & $8 / 15 / 91$ & $<.1$ & $<.1$ & 0 & & & & & & & & & \\
\hline MV-46(44) & $6 / 23 / 92$ & $<.1$ & $<.1$ & 0 & & & & & & & & & \\
\hline MV-36(60) & $7 / 29 / 92$ & $<.1$ & $<.1$ & 0 & & & & & & & & & \\
\hline MV-21(8) & $8 / 4 / 93$ & $<.1$ & $<.1$ & 0 & & & & & & & & & \\
\hline MV-10(28) & $8 / 11 / 94$ & $<.008$ & $<.008$ & 0 & & & & & & & & & \\
\hline MV-56(34) & $8 / 9 / 94$ & $<.008$ & $<.008$ & 0 & & & & & & & & & \\
\hline MV-38(44) & $7 / 24 / 95$ & $<.008$ & $<.008$ & 0 & & & & & & & & & \\
\hline MV-55(60) & $7 / 26 / 95$ & $<.008$ & $<.008$ & 0 & & & & & & & & & \\
\hline
\end{tabular}




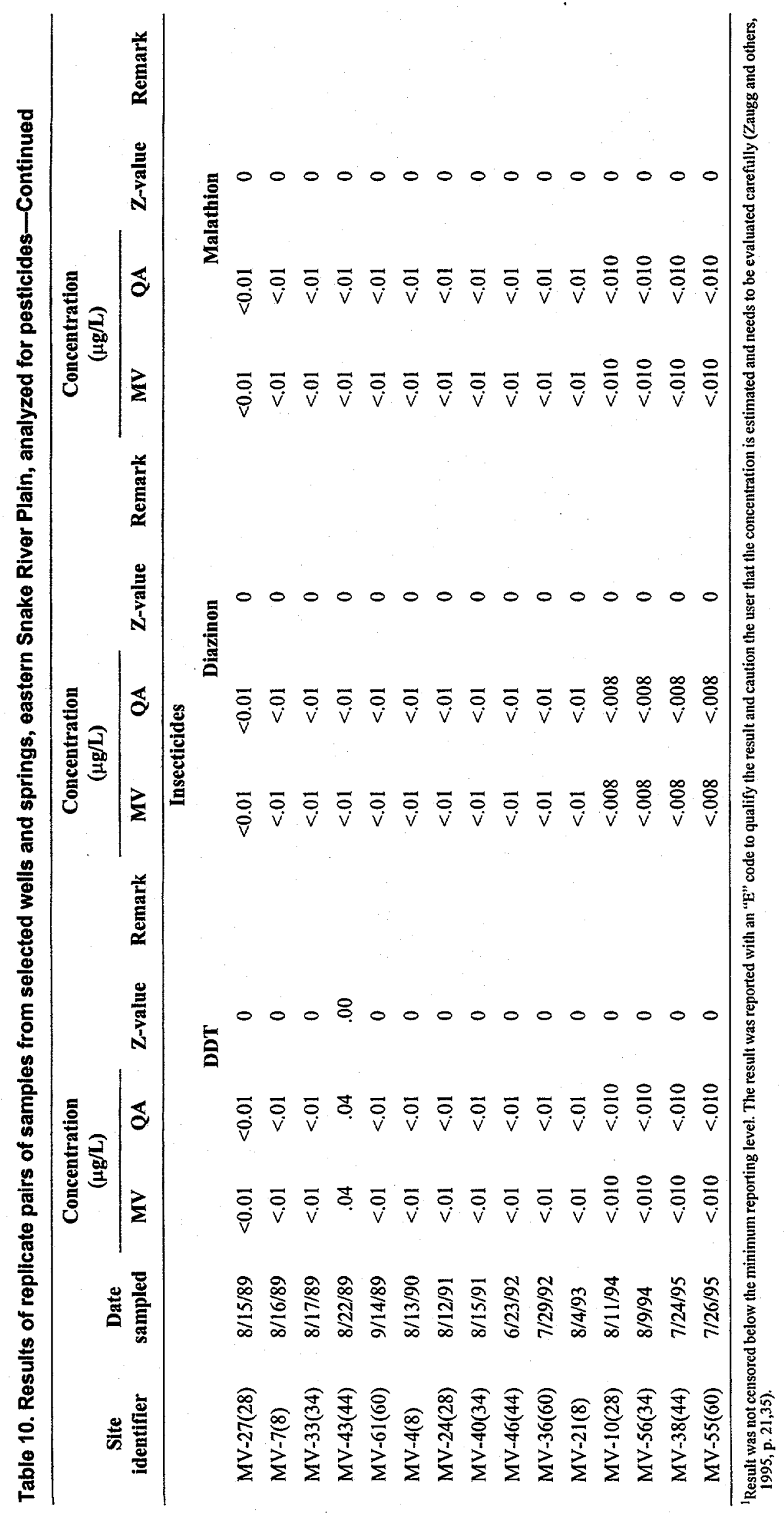




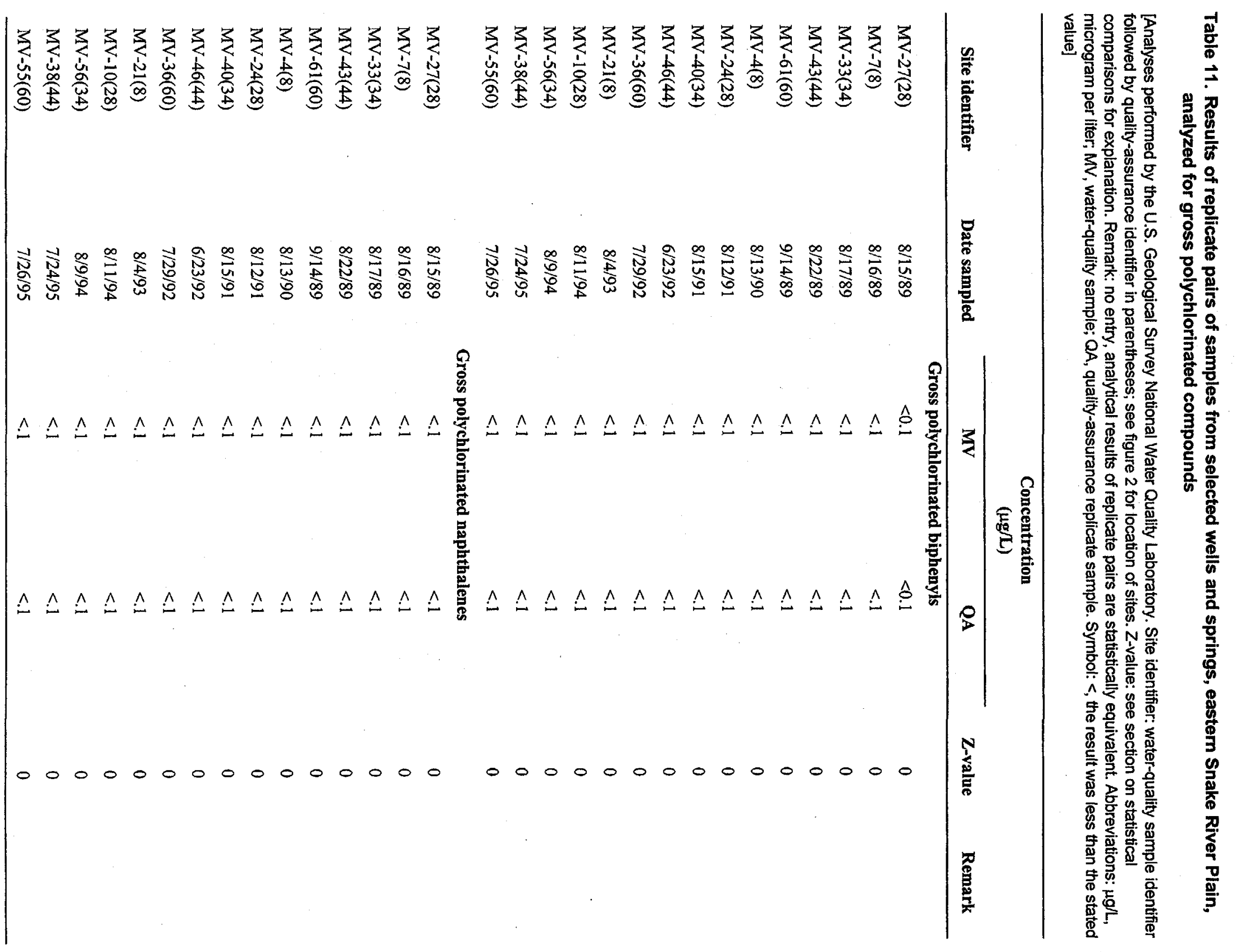


Table 12. Results of replicate pairs of samples from selected wells and springs, eastern Snake River Plain, analyzed for stable isotopes

[Analyses performed by the U.S. Geological Survey National Water Quality Laboratory. Site identifier: water-quality sample identifier followed by quality-assurance identifier in parentheses; see figure 2 for location of sites. Z-value: see section on statistical comparisons for explanation. Remark: no entry, analytical results of replicate pairs are statistically equivalent; $N$, the analytical results are not statistically equivalent. Abbreviations: MV, water-quality sample; QA, quality-assurance replicate sample. Symbol: $\delta$, parts per thousand difference between a sample and a standard expressed as per mil]

\begin{tabular}{|c|c|c|c|c|c|}
\hline \multirow{2}{*}{$\begin{array}{c}\text { Site } \\
\text { identifier }\end{array}$} & \multirow{2}{*}{$\begin{array}{c}\text { Date } \\
\text { sampled }\end{array}$} & \multicolumn{2}{|c|}{ Stable isotope } & \multirow[b]{2}{*}{ Z-value } & \multirow[b]{2}{*}{ Remark } \\
\hline & & MV & QA & & \\
\hline \multicolumn{6}{|c|}{$\delta^{2}$ Hydrogen, (per mil) } \\
\hline$M V-21(8)$ & $8 / 4 / 93$ & $-135 \pm 2$ & $-135 \pm 2$ & 0.00 & \\
\hline MV-10(28) & $8 / 11 / 94$ & $-133 \pm 2$ & $-133 \pm 2$ & .00 & \\
\hline MV-56(34) & $8 / 9 / 94$ & $-135 \pm 2$ & $-137 \pm 2$ & .71 & \\
\hline MV-38(44) & $7 / 24 / 95$ & $-134 \pm 2$ & $-133 \pm 2$ & .35 & \\
\hline MV-55(60) & $7 / 26 / 95$ & $-138 \pm 2$ & $-136 \pm 2$ & .71 & \\
\hline \multicolumn{6}{|c|}{$\delta^{18}$ Oxygen, (per mil) } \\
\hline MV-21(8) & $8 / 4 / 93$ & $-17.98 \pm 0.2$ & $-17.9 \pm 0.2$ & .38 & \\
\hline$M V-10(28)$ & $8 / 11 / 94$ & $-17.26 \pm 0.2$ & $-17.3 \pm 0.2$ & .14 & \\
\hline$M V-56(34)$ & $8 / 9 / 94$ & $-17.81 \pm 0.2$ & $-17.81 \pm 0.2$ & .00 & \\
\hline MV-38(44) & $7 / 24 / 95$ & $-17.34 \pm 0.2$ & $-17.65 \pm 0.2$ & 1.10 & \\
\hline $\mathrm{MV}-55(60)$ & $7 / 26 / 95$ & $-17.85 \pm 0.2$ & $-17.85 \pm 0.2$ & .00 & \\
\hline \multicolumn{6}{|c|}{$\delta^{13}$ Carbon, (per mil) } \\
\hline MV-21(8) & $8 / 4 / 93$ & $-6.3 \pm 0.3$ & $-11 \pm 0.3$ & 11.08 & $\mathrm{~N}$ \\
\hline MV-10(28) & $8 / 11 / 94$ & $-11 \pm 0.3$ & $-11.1 \pm 0.3$ & .24 & \\
\hline MV-56(34) & $8 / 9 / 94$ & $-10.4 \pm 0.3$ & $-10.2 \pm 0.3$ & .47 & \\
\hline MV-38(44) & $7 / 24 / 95$ & $-12.1 \pm 0.3$ & $-12.2 \pm 0.3$ & .24 & \\
\hline MV-55(60) & $7 / 26 / 95$ & $-10.5 \pm 0.3$ & $-10.3 \pm 0.3$ & .47 & \\
\hline \multicolumn{6}{|c|}{$\delta^{34}$ Sulfur, (per mil) } \\
\hline MV-21(8) & $8 / 4 / 93$ & $11.5 \pm 0.2$ & $11.9 \pm 0.2$ & .57 & \\
\hline$M V-10(28)$ & $8 / 11 / 94$ & $12.3 \pm 0.2$ & $12.3 \pm 0.2$ & .00 & \\
\hline MV-56(34) & $8 / 9 / 94$ & $14.1 \pm 0.2$ & $14.2 \pm 0.2$ & .14 & \\
\hline MV-38(44) & $7 / 24 / 95$ & $10.7 \pm 0.2$ & $10.8 \pm 0.2$ & .14 & \\
\hline MV-55(60) & $7 / 26 / 95$ & $13.8 \pm 0.2$ & $13.8 \pm 0.2$ & .00 & \\
\hline \multicolumn{6}{|c|}{$\delta^{15}$ Nitrogen, (per mil) } \\
\hline MV-21(8) & $8 / 4 / 93$ & $5.2 \pm 0.2$ & $5.2 \pm 0.2$ & .00 & \\
\hline$M V-10(28)$ & $8 / 11 / 94$ & $3.9 \pm 0.2$ & $3.2 \pm 0.2$ & 2.47 & $\mathrm{~N}$ \\
\hline MV-56(34) & $8 / 9 / 94$ & $4.4 \pm 0.2$ & $4.1 \pm 0.2$ & 1.06 & \\
\hline MV-38(44) & $7 / 24 / 95$ & $4.1 \pm 0.2$ & $5.0 \pm 0.2$ & 3.18 & $\mathbf{N}$ \\
\hline$M V-55(60)$ & $7 / 26 / 95$ & $5.4 \pm 0.2$ & $5.1 \pm 0.2$ & 1.06 & \\
\hline
\end{tabular}


Table 13. Results of source-solution blanks analyzed for major ions

[Analyses performed by the U.S. Geological Survey National Water Quality Laboratory. Identifier: see section on blanks for explanation. Abbreviations: $\mathrm{mg} / \mathrm{L}$, milligram per liter. Symbol: $<$, the result was less than the stated value. Number in bold indicates the result exceeded two standard deviations]

\begin{tabular}{|c|c|c|c|c|}
\hline Identifier & $\begin{array}{c}\text { Date } \\
\text { prepared }\end{array}$ & & $\begin{array}{c}\text { Concentration } \\
(\mathrm{mg} / \mathrm{L})\end{array}$ & \\
\hline & & Calcium & Magnesium & Sodium \\
\hline$M V-22$ & $11 / 02 / 90$ & 0.07 & 0.04 & $<0.2$ \\
\hline \multirow[t]{2}{*}{ MV-22 } & $8 / 11 / 93$ & .17 & .02 & $<.2$ \\
\hline & & Potassium & Sulfate & Chloride \\
\hline $\mathrm{MV}-22$ & $11 / 02 / 90$ & $<.1$ & $<1$ & .2 \\
\hline \multirow[t]{2}{*}{ MV-22 } & $8 / 11 / 93$ & $<.1$ & $<1$ & $<.1$ \\
\hline & & Fluoride & Bromide & Silica \\
\hline MV-22 & $11 / 02 / 90$ & $<.1$ & $<.01$ & .2 \\
\hline$M V-22$ & $8 / 11 / 93$ & $<.1$ & $<.01$ & $<.01$ \\
\hline
\end{tabular}


Table 14. Results of source-solution blanks and an equipment blank analyzed for dissolved nutrients, cyanide, and organic carbon; and anionic surfactants as methylene blue active substances

[Analyses performed by the U.S. Geological Survey National Water Quality Laboratory. Identifier: see section on blanks for explanation. Abbreviations: $\mathrm{mg} / \mathrm{L}$, milligram per liter; MBAS, anionic surfactants as methylene blue active substances; na, no analysis. Symbol: <, the result was less than the stated value. Numbers in bold indicate the results exceeded two standard deviations]

\begin{tabular}{|c|c|c|c|c|c|}
\hline Identifier & $\begin{array}{c}\text { Date } \\
\text { prepared }\end{array}$ & \multicolumn{3}{|c|}{$\begin{array}{l}\text { Concentration } \\
(\mathbf{m g} / \mathrm{L})\end{array}$} & . \\
\hline \multicolumn{6}{|c|}{ Source-solution blanks } \\
\hline & & $\begin{array}{l}\text { Ammonia, } \\
\text { as nitrogen }\end{array}$ & $\begin{array}{c}\text { Nitrite plus nitrate, } \\
\text { as nitrogen }\end{array}$ & $\begin{array}{l}\text { Nitrite, } \\
\text { as nitrogen }\end{array}$ & $\begin{array}{l}\text { Orthophosphate, } \\
\text { as phosphorous }\end{array}$ \\
\hline MV-22 & $8 / 19 / 89$ & 0.02 & $<0.1$ & $<0.01$ & 0.01 \\
\hline MV-22 & $11 / 02 / 90$ & .01 & $<.1$ & $<.01$ & .02 \\
\hline \multirow[t]{3}{*}{$\mathrm{MV}-22$} & $8 / 11 / 93$ & .02 & $<.05$ & $<.01$ & $<.01$ \\
\hline & & * & & & \\
\hline & & Cyanide & $\begin{array}{c}\text { Dissolved } \\
\text { organic carbon }\end{array}$ & Total MBA's & \\
\hline MV-22 & $8 / 19 / 89$ & na & na & .02 & \\
\hline MV-22 & $11 / 02 / 90$ & $<.01$ & .5 & .01 & \\
\hline \multirow[t]{2}{*}{ MV-22 } & $8 / 11 / 93$ & na & $<.1$ & $<.01$ & \\
\hline & & & Equipment blank & & \\
\hline $\begin{array}{l}\mathrm{MV}- \\
\quad 62(\mathrm{C})\end{array}$ & $11 / 12 / 92$ & na & $<.1$ & na & \\
\hline
\end{tabular}


Table 15. Results of source-solution blanks analyzed for trace elements

[Analyses performed by the U.S. Geological Survey National Water Quality Laboratory. All analyses are for dissolved trace elements, except for whole water, recoverable (WWR) chromium. Identifier: see section on blanks for explanation. Abbreviations: $\mu \mathrm{g} / \mathrm{L}$, microgram per liter; na, no analysis. Symbol: <, the result was less than the stated value]

\begin{tabular}{|c|c|c|c|c|c|c|}
\hline \multirow[t]{2}{*}{ Identifier } & \multirow[t]{2}{*}{$\begin{array}{c}\text { Date } \\
\text { prepared }\end{array}$} & \multicolumn{5}{|c|}{ Concentration $(\mu \mathrm{g} / \mathrm{L})$} \\
\hline & & Aluminum & Arsenic & Barium & Beryllium & Cadmium \\
\hline$M V-22$ & $8 / 19 / 89$ & na & $<1$ & $<2$ & na & $<1$ \\
\hline MV-22 & $11 / 02 / 90$ & na & $<1$ & $<2$ & na & $<1$ \\
\hline \multirow[t]{2}{*}{ MV-22 } & $8 / 11 / 93$ & $<10$ & $<1$ & $<2$ & $<.5$ & $<1$ \\
\hline & & Chromium & Chromium, hexavalent & Chromium, WWR & Cobalt & Copper \\
\hline$M V-22$ & $8 / 19 / 89$ & 2 & na & na & na & na \\
\hline MV-22 & $11 / 02 / 90$ & 1 & $<1$ & $<1$ & na & na \\
\hline \multirow[t]{2}{*}{$M V-22$} & $8 / 11 / 93$ & $<1$ & $<5$ & $<1$ & $<3$ & $<10$ \\
\hline & & Iron & Lead & Lithium & Mercury & Molybdenum \\
\hline MV-22 & $8 / 19 / 89$ & na & $<1$ & na & $<.1$ & na \\
\hline $\mathrm{MV}-22$ & $11 / 02 / 90$ & 4 & 2 & na & $<.1$ & na \\
\hline \multirow[t]{2}{*}{$M V-22$} & $8 / 11 / 93$ & $<3$ & $<1$ & $<4$ & $<.1$ & $<10$ \\
\hline & & Manganese & Nickel & Selenium & Silver & Strontium \\
\hline MV-22 & $8 / 19 / 89$ & na & na & $<1$ & $<1$ & na \\
\hline $\mathrm{MV}-22$ & $11 / 02 / 90$ & na & na & $<1$ & $<1$ & na \\
\hline \multirow[t]{2}{*}{$\mathrm{MV}-22$} & $8 / 11 / 93$ & $<1$ & $<1$ & $<1$ & $<1$ & .7 \\
\hline & & Vanadium & Zinc & & & \\
\hline MV-22 & $8 / 19 / 89$ & na & na & & & \\
\hline$M V-22$ & $11 / 02 / 90$ & na & na & & & \\
\hline$M V-22$ & $8 / 11 / 93$ & $<6$ & 5 & & & \\
\hline
\end{tabular}


Table 16. Results of equipment blanks analyzed for trace elements

[Analyses performed by the Idaho Department of Health and Welfare Laboratory. All analyses are for dissolved trace elements. Identifier: see section on blanks for explanation. Abbreviations: $\mu \mathrm{g} / \mathrm{L}$, microgram per liter; na, no analysis. Symbols: $<$, the result was less than the stated value]

\begin{tabular}{|c|c|c|c|c|c|c|}
\hline Identifier & $\begin{array}{c}\text { Date } \\
\text { prepared }\end{array}$ & & & $\begin{array}{l}\text { mcentration } \\
(\mu \mathrm{g} / \mathrm{L})\end{array}$ & & \\
\hline & & Aluminum & Arsenic & Barium & Beryllium & Cadmium \\
\hline MV-62 & $8 / 15 / 91$ & na & $<10$ & $<100$ & $<5$ & $<1$ \\
\hline MV-62(A) & $6 / 24 / 92$ & $<100$ & $<10$ & $<100$ & $<5$ & $<1$ \\
\hline \multirow[t]{2}{*}{$M V-62(B)$} & $7 / 30 / 92$ & $<100$ & $<10$ & $<100$ & $<5$ & $<1$ \\
\hline & & Chromium & Cobalt & Copper & Iron & Lead \\
\hline MV-62 & $8 / 15 / 91$ & $<3$ & na & na & na & $<5$ \\
\hline MV-62(A) & $6 / 24 / 92$ & $<2$ & $<10$ & $<10$ & $<10$ & $<5$ \\
\hline \multirow[t]{2}{*}{ MV-62(B) } & $7 / 30 / 92$ & $<2$ & $<10$ & $<10$ & $<10$ & $<5$ \\
\hline & & Lithium & Manganese & Mercury & Molybdenum & Nickel \\
\hline MV-62 & $8 / 15 / 91$ & na & na & $<.5$ & na & na \\
\hline MV-62(A) & $6 / 24 / 92$ & $<10$ & $<10$ & $<.5$ & $<10$ & $<10$ \\
\hline \multirow[t]{2}{*}{$M V-62(B)$} & $7 / 30 / 92$ & $<10$ & $<10$ & $<.5$ & $<10$ & $<10$ \\
\hline & & Selenium & Silver & Strontium & Vanadium & Zinc \\
\hline MV-62 & $8 / 15 / 91$ & $<5$ & $<1$ & na & na & na \\
\hline MV-62(A) & $6 / 24 / 92$ & $<5$ & $<1$ & 1.7 & $<10$ & $<2$ \\
\hline MV-62(B) & $7 / 30 / 92$ & $<5$ & $<1$ & $<1$ & $<10$ & $<2$ \\
\hline
\end{tabular}


Table 17. Results of source-solution blanks analyzed for gross radioactivity and radionuclides

IAnalyses by the U.S. Geological Survey National Water Quality Laboratory except for one tritium sample, which was analyzed by Idaho State University (ISU) Environmental Monitoring Laboratory Reported uncertainties are twice the standard deviation. Identifier: see section on blanks for explanation. Abbreviations: $\mu \mathrm{g} / \mathrm{L}$, microgram per liter; $\mathrm{pCl} / \mathrm{h}$, picocurie per liter; na, no analysis. Numbers in bold indicate the results exceeded two standard deviations]

\begin{tabular}{|c|c|c|c|c|c|}
\hline \multirow[t]{2}{*}{ Identifier } & \multirow[t]{2}{*}{$\begin{array}{c}\text { Date } \\
\text { prepared }\end{array}$} & \multicolumn{4}{|c|}{ Concentration } \\
\hline & & $\begin{array}{c}\text { Gross alpha, dissolved, } \\
\text { as uranium, } \\
(\mu \mathrm{g} / \mathrm{L})\end{array}$ & $\begin{array}{l}\text { Gross alpha, dissolved, } \\
\text { as thorium-230, } \\
(\mathrm{pCi} / \mathrm{L})\end{array}$ & $\begin{array}{c}\text { Gross alpha, suspended, } \\
\text { as uranium, } \\
(\mu \mathrm{g} / \mathrm{L})\end{array}$ & $\begin{array}{c}\text { Gross alpha, suspended, } \\
\text { as thorium-230, } \\
(\mathrm{pCi} / \mathrm{L})\end{array}$ \\
\hline MV-22 & $8 / 19 / 89$ & $1.14 \pm 0.35$ & $1.23 \pm 0.38$ & $0.038 \pm 0.045$ & $0.037 \pm 0.044$ \\
\hline MV-22 & $11 / 02 / 90$ & $.135 \pm 0.344$ & $.092 \pm 0.235$ & $-.096 \pm 0.373$ & $-.05 \pm 0.198$ \\
\hline \multirow[t]{2}{*}{ MV-22 } & $8 / 11 / 93$ & $-.125 \pm 0.210$ & $-.070 \pm 0.118$ & na & na \\
\hline & & $\begin{array}{l}\text { Gross beta, dissolved, } \\
\text { as cesium-137, } \\
(\mathbf{p C i} / \mathrm{L})\end{array}$ & $\begin{array}{c}\text { Gross beta, dissolved, } \\
\text { as strontium-90/yttrium-90 } \\
\qquad(\mathrm{pC} / \mathrm{L})\end{array}$ & $\begin{array}{c}\text { Gross beta, suspended, } \\
\text { as cesium-137, } \\
(\text { (pCi/L) }\end{array}$ & $\begin{array}{c}\text { Gross beta, suspended, } \\
\text { as strontium-90/yttrium-90 } \\
(\mathrm{pCi} / \mathrm{L})\end{array}$ \\
\hline MV-22 & $8 / 19 / 89$ & $.19 \pm 0.32$ & $.17 \pm 0.28$ & $-.015 \pm 0.263$ & $-.016 \pm 0.275$ \\
\hline MV-22 & $11 / 02 / 90$ & $-.158 \pm 0.311$ & $-.157 \pm 0.308$ & $-.398 \pm 0.518$ & $-.376 \pm 0.489$ \\
\hline \multirow[t]{2}{*}{ MV-22 } & $8 / 11 / 93$ & $.016 \pm 0.287$ & $.017 \pm 0.297$ & na & na \\
\hline & & $\begin{array}{l}\text { Radon-222, } \\
(\mathrm{pCi} / \mathrm{L})\end{array}$ & $\begin{array}{l}\text { Strontium-90, } \\
\quad(\text { pCi/L) }\end{array}$ & $\begin{array}{l}\text { Tritium, } \\
\text { (pCi/L) }\end{array}$ & $\begin{array}{l}\text { Tritium, ISU, } \\
\quad(p C i / L)\end{array}$ \\
\hline MV-22 & $8 / 19 / 89$ & $11 \pm 49$ & $.060 \pm 0.200$ & $41.6 \pm 25.6$ & $80 \pm 220$ \\
\hline MV-22 & $11 / 02 / 90$ & $53 \pm 41$ & $.333 \pm 0.320$ & $16,650 \pm 570$ & na \\
\hline \multirow[t]{2}{*}{ MV-22 } & $8 / 11 / 93$ & na & $.342 \pm 0.152$ & $18.3 \pm 1.22$ & na \\
\hline & & $\begin{array}{l}\text { Uranium, total isotopic, } \\
(\mu \mathrm{g} / \mathrm{L})\end{array}$ & $\begin{array}{l}\text { Radium-224, } \\
\quad(p C i / L)\end{array}$ & $\begin{array}{l}\text { Radium-226, } \\
\text { (pCi/L) }\end{array}$ & $\begin{array}{l}\text { Radium-228, } \\
\quad(\text { pCi/L) }\end{array}$ \\
\hline MV-22 & $8 / 19 / 89$ & $.00 \pm 0.00$ & $.850 \pm 0.170$ & $.078 \pm 0.018$ & $.707 \pm 0.694$ \\
\hline MV-22 & $11 / 02 / 90$ & $.003 \pm 0.010$ & na & $.086 \pm 0.016$ & $.121 \pm 0.398$ \\
\hline
\end{tabular}


Table 18. Results of source-solution blanks analyzed for gamma radiation

[Analyses performed by the U.S. Geological Survey National Water Quality Laboratory. Identifier: see section on blanks for explanation. Abbreviations: pCi/L, plcocurie per liter; nr, no result reported. Numbers in bold indicate the results exceeded two standard deviations]

\begin{tabular}{|c|c|c|c|c|c|c|}
\hline Identifier & $\begin{array}{c}\text { Date } \\
\text { prepared }\end{array}$ & & & $\begin{array}{c}\text { Concentration } \\
(\mathrm{pCi} / \mathrm{L})\end{array}$ & & \\
\hline . & 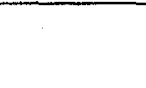 & $\begin{array}{c}\text { Cobalt-60, } \\
\text { (pCi/L) }\end{array}$ & $\begin{array}{c}\text { Potassium-40, } \\
(\text { (pi } / L)\end{array}$ & $\begin{array}{c}\text { Radium-224, } \\
(\text { pCi/L) }\end{array}$ & $\begin{array}{c}\text { Radium-226, } \\
(\text { (pi/L) }\end{array}$ & $\begin{array}{c}\text { Cesium-137 } \\
(\mathrm{pCi} / \mathrm{L})\end{array}$ \\
\hline MV-22 & $8 / 19 / 89$ & $0.36 \pm 0.09$ & $5.88 \pm 1.36$ & $0.85 \pm 0.178$ & $0.53 \pm 0.15$ & $\mathrm{nr}$ \\
\hline MV-22 & $11 / 02 / 90$ & $\mathrm{nr}$ & $\mathrm{nr}$ & $\mathrm{nr}$ & $\mathrm{nr}$ & $-.031 \pm 0.110$ \\
\hline
\end{tabular}


Table 19. Results of source-solution and equipment blanks analyzed for volatile organic compounds

[Analyses performed by the U.S. Geological Survey National Water Quality Laboratory and the Idaho Department of Health and Welfare Laboratory (IDHWL). Identifier: see section on blanks for explanation. Abbreviation: $\mu \mathrm{g} / \mathrm{L}$, microgram per liter. Symbols: <, the result was less than the stated value; -, compound was not detected. Numbers in bold indicate the results exceeded two standard deviations]

\begin{tabular}{|c|c|c|c|}
\hline \multirow[t]{2}{*}{ Identifier } & \multirow[t]{2}{*}{$\begin{array}{c}\text { Date } \\
\text { prepared }\end{array}$} & \multicolumn{2}{|c|}{$\begin{array}{c}\text { Concentration } \\
(\mu \mathrm{g} / \mathrm{L})\end{array}$} \\
\hline & & Chloroform & Methylene chloride \\
\hline \multicolumn{4}{|c|}{ Source-solution blanks, NWQL } \\
\hline MV-22 & $8 / 19 / 89$ & 0.5 & $<0.2$ \\
\hline MV-22 & $11 / 02 / 90$ & $<.2$ & $<.2$ \\
\hline$M V-22$ & $8 / 11 / 93$ & $<.2$ & .3 \\
\hline \multicolumn{4}{|c|}{ Equipment blanks, IDWHL } \\
\hline MV-62 & $8 / 15 / 91$ & .220 & - \\
\hline$M V-62(A)$ & $6 / 24 / 92$ & - & - \\
\hline $\mathrm{MV}-62(\mathrm{~B})$ & $7 / 30 / 92$ & - & - \\
\hline
\end{tabular}


Table 20. Results of an equipment blank, QA-MV, analyzed for volatile organic compounds

[Analyses performed by the U.S. Geological Survey National Water Quality Laboratory. Identifier: see section on blanks for explanation. Abbreviation: $\mu \mathrm{g} / \mathrm{L}$, microgram per liter. Numbers in bold indicate the results exceeded two standard deviations]

\begin{tabular}{|c|c|c|c|c|c|}
\hline \multirow[t]{2}{*}{ Identifier } & \multirow[t]{2}{*}{$\begin{array}{c}\text { Date } \\
\text { prepared }\end{array}$} & \multicolumn{4}{|c|}{$\begin{array}{c}\text { Concentration } \\
(\mu g / L)\end{array}$} \\
\hline & & Benzene & Ethylbenzene & Methylene chloride & Styrene \\
\hline \multirow[t]{2}{*}{ QA-MV } & $12 / 14 / 89$ & 0.2 & 0.3 & 0.3 & 0.2 \\
\hline & & $\begin{array}{c}\text { 1,1,1-Tri- } \\
\text { chloroethane }\end{array}$ & Toluene & Xylene & \\
\hline QA-MV & $12 / 14 / 89$ & .2 & .7 & 4.3 & \\
\hline
\end{tabular}


Table 21. Upper-tail areas for a normal curve

[The statistical table was compiled by J.W. Stegeman (Ott, 1993, p. A-3). The level of significance (or p-value) is the area and must be multiplied by two for two-tailed tests. Number in bold is the level of significance for a one-tailed test when $z$ equals 1.96 ]

\begin{tabular}{|c|c|c|c|c|c|c|c|c|c|c|}
\hline$z$ & .00 & .01 & .02 & .03 & .04 & .05 & .06 & .07 & .08 & .09 \\
\hline 0.00 & .5000 & .4960 & .4920 & .4880 & .4880 & .4801 & .4761 & .4721 & .4681 & .4641 \\
\hline 0.10 & .4602 & .4562 & .4522 & .4483 & .4443 & .4404 & .4364 & .4325 & .4286 & .4247 \\
\hline 0.20 & .4207 & .4168 & .4129 & .4090 & .4052 & .4013 & .3974 & .3936 & .3897 & .3859 \\
\hline 0.30 & .3821 & .3783 & .3745 & .3707 & .3669 & .3632 & .3594 & .3557 & .3520 & .3483 \\
\hline 0.40 & .3446 & .3409 & .3372 & .3336 & .3300 & .3264 & .3228 & .3192 & .3156 & .3121 \\
\hline 0.50 & .3085 & .3050 & .3015 & .2981 & .2946 & .2912 & .2877 & .2843 & .2810 & .2776 \\
\hline 0.60 & .2743 & .2709 & .2676 & .2643 & .2611 & .2578 & .2546 & .2514 & .2483 & .2451 \\
\hline 0.70 & .2420 & .2389 & .2258 & .2327 & .2296 & .2266 & .2236 & .2206 & .2177 & .2148 \\
\hline 0.80 & .2119 & .2090 & .2061 & .2033 & .2005 & .1977 & 1949 & .1922 & .1894 & .1867 \\
\hline 0.90 & .1841 & .1814 & .1788 & .1762 & .1736 & .1711 & .1685 & .1660 & .1635 & .1611 \\
\hline 1.00 & .1587 & .1562 & .1539 & .1515 & .1492 & .1469 & .1446 & .1423 & .1401 & .1379 \\
\hline 1.10 & .1357 & .1335 & .1314 & .1292 & .1271 & .1251 & .1230 & .1210 & .1190 & .1170 \\
\hline 1.20 & .1151 & .1131 & .1112 & .1093 & .1075 & .1056 & .1038 & .1020 & .100 & .0985 \\
\hline 1.30 & .0968 & .0951 & .0934 & .0918 & .0901 & .0885 & .0869 & .0853 & .0838 & .0823 \\
\hline 1.40 & .0808 & .0793 & .0778 & .0764 & .0749 & .0735 & .0721 & .0708 & .0694 & .0681 \\
\hline 1.50 & .0668 & .0655 & .0643 & .0630 & .0618 & .0606 & .0594 & .0582 & .0571 & .0559 \\
\hline 1.60 & .0548 & .0537 & .0526 & .0516 & .0505 & .0495 & .0485 & .0475 & .0465 & .0455 \\
\hline 1.70 & .0446 & .0436 & .0427 & .0418 & .0409 & .0401 & .0392 & .0384 & .0375 & .0367 \\
\hline 1.80 & .0359 & .0351 & .0344 & .0336 & .0329 & .0322 & .0314 & .0307 & .0301 & .0294 \\
\hline 1.90 & .0287 & .0281 & .0274 & .0268 & .0262 & .0256 & .0250 & .0244 & .0239 & .0233 \\
\hline 2.00 & .0228 & .0222 & .0217 & .0212 & .0207 & .0202 & .0197 & .0192 & .0188 & .0183 \\
\hline 2.10 & .0179 & .0174 & .0170 & .0166 & .0162 & .0158 & .0154 & .0150 & .0146 & .0143 \\
\hline 2.20 & .0139 & .0136 & .0132 & .0129 & .0125 & .0122 & .0119 & .0116 & .0113 & .0110 \\
\hline 2.30 & .0107 & .0104 & .0102 & .0099 & .0096 & .0094 & .0091 & .0089 & .0087 & .0084 \\
\hline 2.40 & .0082 & .0080 & .0078 & .0075 & .0073 & .0071 & .0069 & .0068 & .0066 & .0064 \\
\hline 2.50 & .0062 & .0060 & .0059 & .0057 & .0055 & .0054 & .0052 & .0051 & .0049 & .0048 \\
\hline 2.60 & .0047 & .0045 & .0044 & .0043 & .0041 & .0040 & .0039 & .0038 & .0037 & .0036 \\
\hline 2.70 & .0035 & .0034 & .0033 & .0032 & .0031 & .0030 & .0029 & .0028 & .0027 & .0026 \\
\hline 2.80 & .0026 & .0025 & .0024 & .0023 & .0023 & .0022 & .0021 & .0021 & .0020 & .0019 \\
\hline 2.90 & .0019 & .0018 & .0018 & .0017 & .0016 & .0016 & .0015 & .0015 & .0014 & .0014 \\
\hline 3.00 & .0013 & .0013 & .0013 & .0012 & .0012 & .0011 & .0011 & .0011 & .0010 & .0010 \\
\hline & & & \multicolumn{2}{|c|}{ z } & & \multicolumn{2}{|c|}{ Area } & & & \\
\hline & & & \multicolumn{2}{|c|}{3.500} & & \multicolumn{2}{|c|}{.00023263} & & & \\
\hline & & & \multicolumn{2}{|c|}{4,000} & & \multicolumn{2}{|c|}{.00003167} & & & \\
\hline & & & \multicolumn{2}{|c|}{4.500} & & \multicolumn{2}{|c|}{.00000640} & & & \\
\hline & & & \multicolumn{2}{|c|}{5.000} & & \multicolumn{2}{|c|}{.00000029} & & & \\
\hline
\end{tabular}


Table 22. Volatile organic compounds, Chemical Abstracts Service (CAS) Registry numbers, minimum reporting levels, and years analyzed

[The minimum reporting levels are 0.2 micrograms per liter except where noted (Rose and Schroeder, 1995; Timme, 1994,1995)]

\begin{tabular}{|c|c|c|c|c|c|c|}
\hline Compound & $\begin{array}{c}\text { CAS Registry } \\
\text { number }\end{array}$ & $1989-1991$ & 1992 & 1993 & 1994 & 1995 \\
\hline Acrolein $^{1}$ & $107-02-8$ & & $\mathrm{x}$ & $\mathbf{x}$ & $x$ & \\
\hline Acrylonitrile ${ }^{l}$ & $107-13-1$ & & $x$ & $\mathrm{x}$ & $\mathrm{x}$ & \\
\hline Benzene & $71-43-2$ & $x$ & $\mathrm{x}$ & $x$ & $\mathrm{x}$ & $\mathrm{x}$ \\
\hline Bromobenzene & $108-86-1$ & & $\mathrm{x}$ & $\mathrm{x}$ & $\mathrm{x}$ & $\mathrm{x}$ \\
\hline Bromochloromethane & $74-97-5$ & & $\mathrm{x}$ & $\mathrm{x}$ & $\mathrm{x}$ & $\mathrm{x}$ \\
\hline Bromodichloromethane & $75-27-4$ & $\mathrm{x}$ & $\mathrm{x}$ & $\mathrm{x}$ & $\mathrm{x}$ & $x$ \\
\hline Bromoform & $75-25-2$ & $\mathrm{x}$ & $\mathrm{x}$ & $\mathrm{x}$ & $x$ & $\mathrm{x}$ \\
\hline Bromomethane & $74-83-9$ & $\mathrm{x}$ & $\mathbf{x}$ & $\mathrm{x}$ & $\mathrm{x}$ & $\mathrm{x}$ \\
\hline$n$-Butylbenzene & $104-51-8$ & & $\mathrm{x}$ & $x$ & $\mathrm{x}$ & $\mathrm{x}$ \\
\hline sec-Butylbenzene & $135-98-8$ & & $\mathrm{x}$ & $\mathrm{x}$ & $\mathbf{x}$ & $x$ \\
\hline tert-Butylbenzene & $98-06-6$ & & $\mathrm{x}$ & $\mathrm{x}$ & $\mathrm{x}$ & $\mathrm{x}$ \\
\hline Carbon tetrachloride & $56-23-5$ & $x$ & $\mathrm{x}$ & $\mathrm{x}$ & $x$ & $x$ \\
\hline Chlorobenzene & $108-90-7$ & $x$ & $\mathrm{x}$ & $x$ & $\mathrm{x}$ & $\mathrm{x}$ \\
\hline Chloroethane & $75-00-3$ & $\mathrm{x}$ & $\mathrm{x}$ & $\mathbf{x}$ & $\mathrm{x}$ & $\mathrm{x}$ \\
\hline 2-Chloroethyl vinyl ether ${ }^{2}$ & $110-75-8$ & $x$ & $\mathrm{x}$ & $\mathrm{x}$ & $\mathrm{x}$ & $x$ \\
\hline Chloroform & $67-66-3$ & $\mathrm{x}$ & $x$ & $\mathrm{x}$ & $\mathrm{x}$ & $\mathrm{x}$ \\
\hline Chloromethane & $74-87-3$ & $x$ & $\mathrm{x}$ & $x$ & $\mathrm{x}$ & $\mathrm{x}$ \\
\hline 2-Chlorotoluene & $95-49-8$ & & $x$ & $\mathrm{x}$ & $x$ & $\mathrm{x}$ \\
\hline 4-Chlorotoluene & $106-43-4$ & & $\mathrm{x}$ & $\mathrm{x}$ & $\mathrm{x}$ & $x$ \\
\hline Dibromochloromethane & $124-48-1$ & $\mathrm{x}$ & $\mathrm{x}$ & $\mathrm{x}$ & $\mathrm{x}$ & $\mathrm{x}$ \\
\hline 1,2-Dibromo-3-chloropropane ${ }^{2}$ & $96-12-8$ & & $\mathrm{x}$ & $\mathrm{x}$ & $\mathrm{x}$ & $\mathrm{x}$ \\
\hline 1,2-Dibromoethane & $106-93-4$ & $\mathrm{x}$ & $x$ & $\mathrm{x}$ & $\mathrm{x}$ & $x$ \\
\hline Dibromomethane & $74-95-3$ & & $\mathrm{x}$ & $\mathrm{x}$ & $x$ & $x$ \\
\hline 1,2-Dichlorobenzene & $95-50-1$ & $\mathrm{x}$ & $\mathrm{x}$ & $\mathrm{x}$ & $\mathbf{x}$ & $\mathrm{x}$ \\
\hline 1,3-Dichlorobenzene & $541-73-1$ & $x$ & $\mathrm{x}$ & $\mathrm{x}$ & $\mathrm{x}$ & $\mathrm{x}$ \\
\hline 1,4-Dichlorobenzene & $106-46-7$ & $x$ & $\mathrm{x}$ & $\mathrm{x}$ & $\mathrm{x}$ & $x$ \\
\hline Dichlorodifluoromethane & $75-71-8$ & $x$ & $\mathrm{x}$ & $\mathrm{x}$ & $\mathbf{x}$ & $\mathrm{x}$ \\
\hline 1,1-Dichloroethane & $75-34-3$ & $\mathrm{x}$ & $\mathrm{x}$ & $x$ & $\mathbf{x}$ & $\mathrm{x}$ \\
\hline 1,2-Dichloroethane & $107-06-2$ & $x$ & $\mathbf{x}$ & $\mathrm{x}$ & $x$ & $\mathrm{x}$ \\
\hline 1,1-Dichloroethene & $75-35-4$ & $x$ & $\mathrm{x}$ & $\mathrm{x}$ & $x$ & $\mathrm{x}$ \\
\hline cis-1,2-Dichloroethene & $156-59-4$ & & $\mathbf{x}$ & $\mathrm{x}$ & $\mathrm{x}$ & $\mathrm{x}$ \\
\hline trans-1,2-Dichloroethene & $156-60-5$ & $x$ & $x$ & $\mathrm{x}$ & $\mathrm{x}$ & $\mathrm{x}$ \\
\hline 1,2-Dichloropropane & $78-87-5$ & $x$ & $x$ & $x$ & $x$ & $x$ \\
\hline 1,3-Dichloropropane & $142-28-9$ & & $x$ & $x$ & $x$ & $x$ \\
\hline 2,2-Dichloropropane & $590-20-7$ & & $x$ & $\mathrm{x}$ & $\mathrm{x}$ & $\mathrm{x}$ \\
\hline 1,1-Dichloropropene & $563-58-6$ & $x$ & $\mathrm{x}$ & $\mathrm{x}$ & $\mathrm{x}$ & $\mathrm{x}$ \\
\hline$c i s$-1,3-Dichloropropene & $10061-01-5$ & $x$ & $x$ & $x$ & $\mathrm{x}$ & $\mathrm{x}$ \\
\hline trans-1,3-Dichloropropene & $10061-02-6$ & $x$ & $\mathrm{x}$ & $\mathrm{x}$ & $\mathrm{x}$ & $\mathrm{x}$ \\
\hline
\end{tabular}


Table 22. Volatile organic compounds, Chemical Abstracts Service (CAS) Registry numbers, minimum reporting levels, and years analyzed-Continued

\begin{tabular}{|c|c|c|c|c|c|c|}
\hline Compound & $\begin{array}{l}\text { CAS Registry } \\
\text { number }\end{array}$ & 1989-1991 & 1992 & 1993 & 1994 & 1995 \\
\hline Ethylbenzene & $100-41-4$ & $\mathrm{x}$ & $x$ & $x$ & $x$ & $x$ \\
\hline Hexachlorobutadiene & $87-68-3$ & & $\mathrm{x}$ & $\mathrm{x}$ & $\mathrm{x}$ & $x$ \\
\hline Isopropylbenzene & $98-82-8$ & & $\mathrm{x}$ & $\mathrm{x}$ & $\mathrm{x}$ & $\mathrm{x}$ \\
\hline$p$-Isopropyltoluene & $99-87-6$ & & $\mathrm{x}$ & $\mathrm{x}$ & $\mathrm{x}$ & $x$ \\
\hline Methylene chloride & $75-09-2$ & $\mathrm{x}$ & $\mathrm{x}$ & $\mathrm{x}$ & $\mathrm{x}$ & $\mathbf{x}$ \\
\hline Methyl tert-butylether ${ }^{2}$ & $1634-04-4$ & & $\mathrm{x}$ & $\mathrm{x}$ & $x$ & $\mathrm{x}$ \\
\hline Naphthalene & $91-20-3$ & & $x$ & $\mathrm{x}$ & $\mathrm{x}$ & $\mathrm{x}$ \\
\hline$n$-Propylbenzene & $103-65-1$ & & $\mathrm{x}$ & $\mathrm{x}$ & $\mathrm{x}$ & $\mathrm{x}$ \\
\hline Styrene & $100-42-5$ & $\mathrm{x}$ & $\mathrm{x}$ & $\mathrm{x}$ & $\mathrm{x}$ & $\mathrm{x}$ \\
\hline 1,1,1,2-Tetrachloroethane & $630-20-6$ & & $x$ & $x$ & $\mathrm{x}$ & $\mathrm{x}$ \\
\hline 1,1,2,2-Tetrachloroethane & $79-34-5$ & $\mathrm{x}$ & $x$ & $x$ & $x$ & $\mathrm{x}$ \\
\hline Tetrachloroethene & $127-18-4$ & $\mathrm{x}$ & $\mathrm{x}$ & $\mathrm{x}$ & $x$ & $\mathrm{x}$ \\
\hline Toluene & $108-88-3$ & $x$ & $\mathrm{x}$ & $\mathrm{x}$ & $\mathrm{x}$ & $\mathrm{x}$ \\
\hline 1,2,3-Trichlorobenzene & $87-61-6$ & & $\mathrm{x}$ & $\mathrm{x}$ & $x$ & $\mathrm{x}$ \\
\hline 1,2,4-Trichlorobenzene & $120-82-1$ & & $\mathrm{x}$ & $\mathrm{x}$ & $\mathrm{x}$ & $x$ \\
\hline 1,1,1-Trichloroethane & $71-55-6$ & $\mathrm{x}$ & $\mathrm{x}$ & $\mathrm{x}$ & $\mathrm{x}$ & $\mathrm{x}$ \\
\hline 1,1,2-Trichloroethane & $79-00-5$ & $\mathrm{x}$ & $x$ & $\mathrm{x}$ & $\mathrm{x}$ & $\mathrm{x}$ \\
\hline Trichloroethene & $79-01-6$ & $\mathrm{x}$ & $\mathrm{x}$ & $\mathrm{x}$ & $\mathrm{x}$ & $\mathrm{x}$ \\
\hline Trichlorofluoromethane & $75-69-4$ & $\mathrm{x}$ & $\mathrm{x}$ & $\mathrm{x}$ & $\mathrm{x}$ & $\mathrm{x}$ \\
\hline 1,2,3-Trichloropropane & $96-18-4$ & & $\mathrm{x}$ & $\mathrm{x}$ & $x$ & $\mathrm{x}$ \\
\hline 1,1,2-Trichloro 1,2,2-trifluoromethane ${ }^{3}$ & $76-13-1$ & & $\mathrm{x}$ & $\mathrm{x}$ & $\mathrm{x}$ & $\mathrm{x}$ \\
\hline 1,2,4-Trimethylbenzene & $95-63-6$ & & $x$ & $\mathrm{x}$ & $\mathrm{x}$ & $\mathbf{x}$ \\
\hline 1,3,5-Trimethylbenzene & $108-67-8$ & & $\mathrm{x}$ & $\mathrm{x}$ & $\mathrm{x}$ & $\mathrm{x}$ \\
\hline Vinyl chloride & $75-01-4$ & $\mathrm{x}$ & $\mathrm{x}$ & $\mathrm{x}$ & $\mathrm{x}$ & $\mathrm{x}$ \\
\hline Xylenes $(\text { meta- })^{4}$ & $108-38-3$ & $x$ & $x$ & $\mathrm{x}$ & $\mathrm{x}$ & $x$ \\
\hline (para-) & $106-42-3$ & $x$ & $\mathrm{x}$ & $\mathrm{x}$ & $\mathrm{x}$ & $x$ \\
\hline (ortho-) & $95-47-6$ & $x$ & $\mathrm{x}$ & $\mathrm{x}$ & $\mathrm{x}$ & $\mathrm{x}$ \\
\hline
\end{tabular}

${ }^{1}$ The reporting level is 20 microgram per liter.

${ }^{2}$ The reporting level is 1 microgram per liter.

${ }^{3}$ In 1995 , the reporting level was changed from 0.5 to 0.2 microgram per liter.

${ }^{4} X y l e n e s$ are reported as a total of meta, para, and ortho. 
Table 23. Pesticides and gross polychlorinated compounds, Chemical Abstracts Service (CAS) Registry numbers, minimum reporting levels, and years analyzed

[Minimum reporting levels (MRL's) are in micrograms per liter (Pritt and Jones, 1989; A.C. Watterson and A.T. Kashuba, U.S.

Geological Survey, written commun., 1993; P.J. Timme, 1994, 1995) Beginning in 1994, lower MRL's (in parentheses) were used]

\begin{tabular}{|c|c|c|c|c|c|c|}
\hline Compound & $\begin{array}{l}\text { CAS Registry } \\
\text { number }\end{array}$ & MRL & 1989-1992 & 1993 & 1994 & 1995 \\
\hline . & \multicolumn{2}{|c|}{ Whole water, recoverable pesticides } & & & & \\
\hline Acetochlor & $34256-82-1$ & $(0.009)$ & & & & $\mathbf{x}$ \\
\hline Alachlor & $15972-60-8$ & $.1(.009)$ & $\mathrm{x}$ & $\mathrm{x}$ & $\mathrm{x}$ & $\mathrm{x}$ \\
\hline Aldicarb & $116-06-3$ & .5 & $\mathrm{x}$ & $\mathrm{x}$ & & $\mathrm{x}$ \\
\hline Aldicarb sufone & $1646-88-4$ & .5 & $\mathrm{x}$ & $\mathrm{x}$ & & \\
\hline Aldicarb sulfoxide & $1646-87-3$ & .5 & $\mathbf{x}$ & $\mathrm{x}$ & & \\
\hline Aldrin & $309-00-2$ & .01 & $x$ & $x$ & $\mathrm{x}$ & $\mathrm{x}$ \\
\hline Ametryn & $834-12-8$ & .1 & $\mathrm{x}$ & $\mathrm{x}$ & & \\
\hline Atrazine & $1912-24-9$ & $.1(.017)$ & $\mathrm{x}$ & $\mathrm{x}$ & $\mathrm{x}$ & $\mathrm{x}$ \\
\hline Azinphos methyl- & $86-50-0$ & $(.038)$ & & & $\mathrm{x}$ & $\mathrm{x}$ \\
\hline Baygon (Propoxur) & $204-043-8$ & .5 & & $\mathrm{x}$ & & $\mathrm{x}$ \\
\hline Benfluralin & $1861-40-1$ & $(.013)$ & & & $\mathrm{x}$ & $x$ \\
\hline Bromacil & $314-40-9$ & .2 & & $\mathrm{x}$ & & \\
\hline Butachlor & $23184-66-9$ & .1 & & $\mathrm{x}$ & & \\
\hline Butylate & $2008-41-5$ & $(.008)$ & & & $x$ & $\mathrm{x}$ \\
\hline Carbaryl (Sevin) & $63-25-2$ & $.5(.046)$ & $\mathrm{x}$ & $x$ & $x$ & $\mathbf{x}$ \\
\hline Carbofuran & $1563-66-2$ & $.5(.013)$ & $\mathrm{x}$ & $\mathrm{x}$ & $x$ & $\mathrm{x}$ \\
\hline Carboxin & $5234-68-4$ & .2 & & $\mathrm{x}$ & & \\
\hline Chlordane & $57-74-9$ & .1 & $\mathrm{x}$ & $x$ & $\mathrm{x}$ & $\mathbf{x}$ \\
\hline Chlorpyrifos (Dursban) & $2921-88-2$ & $.01(.005)$ & $\mathrm{x}$ & $\mathrm{x}$ & $\mathrm{x}$ & $\mathrm{x}$ \\
\hline Cyanazine & $21725-46-2$ & $.1(.013)$ & $\mathrm{x}$ & $\mathrm{x}$ & $\mathrm{x}$ & $\mathrm{x}$ \\
\hline Cycloate & $1134-23-2$ & .1 & & $\mathrm{x}$ & & \\
\hline 2,4-D & $94-75-7$ & .01 & $\mathrm{x}$ & $\mathrm{x}$ & $\mathrm{x}$ & $\mathrm{x}$ \\
\hline Dacthal (DCPA) & $1861-32-1$ & $(.004)$ & & & $\mathrm{x}$ & $\mathrm{x}$ \\
\hline$p, p^{\prime}-\mathrm{DDD}$ & $72-54-8$ & $.01(.010)$ & $\mathbf{x}$ & $\mathrm{x}$ & $\mathrm{x}$ & $\mathbf{x}$ \\
\hline$p, p^{\prime}-\mathrm{DDE}$ & $72-55-9$ & .01 & $\mathrm{x}$ & $\mathrm{x}$ & $\mathbf{x}$ & $\mathbf{x}$ \\
\hline$p, p^{\prime}-\mathrm{DDT}$ & $50-29-3$ & .01 & $\mathrm{x}$ & $\mathrm{x}$ & $\mathrm{x}$ & $\mathrm{x}$ \\
\hline Deethylatrazine & $6190-65-4$ & $.2(.007)$ & & $\mathrm{x}$ & $\mathrm{x}$ & $\mathrm{x}$ \\
\hline Deisopropylatrazine & $1007-28-9$ & .2 & & $\mathrm{x}$ & & \\
\hline Diazinon & $333-41-5$ & $.01(.008)$ & $\mathrm{x}$ & $x$ & $\mathrm{x}$ & $\mathbf{x}$ \\
\hline Dieldrin & $60-57-1$ & $.01(.008)$ & $\mathrm{x}$ & $x$ & $\mathrm{x}$ & $\mathrm{x}$ \\
\hline Diethylaniline & $579-66-8$ & $(.006)$ & & & $\mathrm{x}$ & $\mathrm{x}$ \\
\hline Dimethoate & $60-51-5$ & $(.024)$ & & & $\mathrm{x}$ & \\
\hline Diphenamid & $957-51-7$ & .1 & & $\mathrm{x}$ & & \\
\hline Disulfoton (Di-syston) & $298-04-4$ & $.01(.028)$ & $\mathrm{x}$ & $\mathrm{x}$ & $\mathrm{x}$ & $\mathbf{x}$ \\
\hline 2,4-DP & $120-36-5$ & .01 & $\mathbf{x}$ & $\mathrm{x}$ & $\mathrm{x}$ & $\mathrm{x}$ \\
\hline Endosulfan & $115-29-7$ & .01 & $x$ & $\mathrm{x}$ & $x$ & $x$ \\
\hline Endrin & $72-20-8$ & .01 & $\mathrm{x}$ & $\mathrm{x}$ & $x$ & $x$ \\
\hline
\end{tabular}


Table 23. Pesticides and gross polychlorinated compounds, Chemical Abstracts Service (CAS) Registry numbers, minimum reporting levels, and years analyzed-Continued

\begin{tabular}{|c|c|c|c|c|c|c|}
\hline Compound & $\begin{array}{l}\text { CAS Registry } \\
\text { number }\end{array}$ & MRL & 1989-1992 & 1993 & 1994 & 1995 \\
\hline Eptam (EPTC) & $759-94-4$ & $(.005)$ & & & $x$ & $x$ \\
\hline Ethalfluralin & $55283-68-6$ & $(.013)$ & & & $x$ & $\mathrm{x}$ \\
\hline Ethion & $563-12-2$ & .01 & $\mathrm{x}$ & $x$ & $\mathrm{x}$ & $\mathrm{x}$ \\
\hline Ethoprop & $13194-48-4$ & $(.012)$ & & & $\mathrm{x}$ & $\mathrm{x}$ \\
\hline Ethyl parathion & $56-38-2$ & $(.022)$ & & & $\mathrm{x}$ & $\mathrm{x}$ \\
\hline Fonofos & $944-22-9$ & $.01(.008)$ & $x$ & $x$ & $\mathrm{x}$ & $\mathbf{x}$ \\
\hline $\mathrm{HCH}$, alpha- & $319-84-6$ & $(.007)$ & & & $\mathrm{x}$ & $\mathbf{x}$ \\
\hline $\mathrm{HCH}$, gamma- (Lindane) & $58-89-9$ & $.01(.011)$ & $x$ & $x$ & $x$ & $\mathrm{x}$ \\
\hline Heptachlor & $76-44-8$ & .01 & $\mathbf{x}$ & $\mathrm{x}$ & $\mathrm{x}$ & $\mathrm{x}$ \\
\hline Heptachlor epoxide & $1024-57-3$ & .01 & $x$ & $x$ & $x$ & $\mathrm{x}$ \\
\hline Hexazinone & $51235-04-2$ & .2 & & $\mathrm{x}$ & & \\
\hline 3-Hydroxycarbofuran & $16655-82-6$ & .5 & $\mathrm{x}$ & $\mathrm{x}$ & & \\
\hline Linuron & $330-55-2$ & $(.039)$ & & & $\mathrm{x}$ & $\mathrm{x}$ \\
\hline Malathion & $121-75-5$ & $.01(.010)$ & $\mathrm{x}$ & $\mathrm{x}$ & $x$ & $\mathrm{x}$ \\
\hline Methiocarb & $2032-65-7$ & .5 & & $\mathrm{x}$ & & $\mathrm{x}$ \\
\hline Methomyl & $16753-77-5$ & .5 & $\mathrm{x}$ & $\mathrm{x}$ & & $\mathbf{x}$ \\
\hline Methoxychlor & $72-43-5$ & .01 & $\mathbf{x}$ & $x$ & $x$ & $\mathrm{x}$ \\
\hline Methyl parathion & $298-0-0$ & $.01(.035)$ & $\mathrm{x}$ & $\mathrm{x}$ & $\mathrm{x}$ & $\mathrm{x}$ \\
\hline Methyl trithion & $953-17-3$ & .01 & $\mathrm{x}$ & & & \\
\hline Metolachlor & $51218-45-2$ & $.1(.009)$ & $\mathrm{x}$ & $\mathrm{x}$ & $x$ & $\mathrm{x}$ \\
\hline Metribuzin & $21087-64-9$ & $.1(.012)$ & $\mathrm{x}$ & $\mathrm{x}$ & $x$ & $\mathrm{x}$ \\
\hline Mirex & $2385-85-3$ & .01 & $\mathrm{x}$ & $\mathrm{x}$ & $\mathrm{x}$ & $x$ \\
\hline Molinate & $2212-67-1$ & $(.007)$ & & & $x$ & $\mathrm{x}$ \\
\hline 1-Naphthol & $90-15-3$ & .5 & $\mathrm{x}$ & $\mathrm{x}$ & & $\mathrm{x}$ \\
\hline Napropamide & $15299-99-7$ & $(.010)$ & & & $\mathrm{x}$ & $\mathrm{x}$ \\
\hline Oxamyl & $23135-22-0$ & .5 & $\mathrm{x}$ & $\mathrm{x}$ & & \\
\hline Parathion & $56-38-2$ & .01 & $\mathrm{x}$ & $\mathrm{x}$ & $\mathbf{x}$ & $\mathrm{x}$ \\
\hline Pebulate & $1114-71-2$ & $(.009)$ & & & $x$ & $x$ \\
\hline Pendimethalin & $40487-42-1$ & $(.018)$ & & & $\mathrm{x}$ & $\mathrm{x}$ \\
\hline cis-Permethrine & $61949-76-6$ & $(.019)$ & & & $x$ & $\mathrm{x}$ \\
\hline Perthane & $72-56-0$ & .1 & $\mathrm{x}$ & $\mathrm{x}$ & $\mathrm{x}$ & $\mathrm{x}$ \\
\hline Phorate & $298-02-2$ & $.01(.011)$ & $\mathrm{x}$ & $\mathrm{x}$ & $\mathrm{x}$ & $\mathrm{x}$ \\
\hline Prometon & $1610-18-0$ & .1 & $\mathrm{x}$ & $x$ & $\mathrm{x}$ & $\mathrm{x}$ \\
\hline Prometryn & $7287-19-6$ & .1 & $\mathrm{x}$ & $\mathrm{x}$ & & \\
\hline Pronamide & $23950-58-5$ & $(.009)$ & & & $\mathrm{x}$ & $\mathrm{x}$ \\
\hline Propachlor & $1918-16-7$ & $.1(.015)$ & & $\mathrm{x}$ & $\mathrm{x}$ & $\mathrm{x}$ \\
\hline Propanil & $709-98-8$ & $(.016)$ & & & $\mathrm{x}$ & $x$ \\
\hline Propargite & $2312-35-8$ & $(.006)$ & & & $x$ & \\
\hline Propazine & $139-40-2$ & .1 & $\mathrm{x}$ & $\mathrm{x}$ & & \\
\hline
\end{tabular}


Table 23. Pesticides and gross polychlorinated compounds, Chemical Abstracts Service (CAS) Registry numbers, minimum reporting levels, and years analyzed-Continued

\begin{tabular}{lllllll}
\hline \multicolumn{1}{c}{ Compound } & $\begin{array}{c}\text { CAS Registry } \\
\text { number }\end{array}$ & MRL & 1989-1992 & 1993 & $\mathbf{1 9 9 4}$ & $\mathbf{1 9 9 5}$ \\
\hline Propargite I \& II & $13071-79-9$ & $(.011)$ & & & & $\mathrm{x}$ \\
Propham & $122-42-9$ & .5 & $\mathrm{x}$ & $\mathrm{x}$ & & $\mathrm{x}$ \\
Simazine & $122-34-9$ & $.1(.008)$ & $\mathrm{x}$ & $\mathrm{x}$ & $\mathrm{x}$ & $\mathrm{x}$ \\
Simetryn & $1014-70-6$ & .1 & $\mathrm{x}$ & $\mathrm{x}$ & & \\
$2,4,5-\mathrm{T}$ & $93-76-5$ & .01 & $\mathrm{x}$ & $\mathrm{x}$ & $\mathrm{x}$ & $\mathrm{x}$ \\
Tebuthiuron & $34014-18-1$ & $(.015)$ & & & $\mathrm{x}$ & $\mathrm{x}$ \\
Terbacil & $5902-51-2$ & $.2(.030)$ & & $\mathrm{x}$ & $\mathrm{x}$ & $\mathrm{x}$ \\
Terbufos & $13071-79-9$ & $(.012)$ & & $\mathrm{x}$ & $\mathrm{x}$ & $\mathrm{x}$ \\
Thiobencarb & $28249-77-6$ & $(.008)$ & & & $\mathrm{x}$ & $\mathrm{x}$ \\
$2,4,5-\mathrm{TP}$ (Silvex) & $93-72-1$ & 0.01 & $\mathrm{x}$ & $\mathrm{x}$ & $\mathrm{x}$ & $\mathrm{x}$ \\
Toxaphene & $8001-35-2$ & 1.0 & $\mathrm{x}$ & $\mathrm{x}$ & $\mathrm{x}$ & $\mathrm{x}$ \\
Triallate & $2303-17-5$ & $(.008)$ & & & $\mathrm{x}$ & $\mathrm{x}$ \\
Tribufos (DEF) & $78-48-8$ & .01 & & $\mathrm{x}$ & $\mathrm{x}$ & $\mathrm{x}$ \\
Trifluralin & $1582-09-8$ & $.1(.012)$ & $\mathrm{x}$ & $\mathrm{x}$ & $\mathrm{x}$ & $\mathrm{x}$ \\
Trithion & $786-19-6$ & .01 & $\mathrm{x}$ & $\mathrm{x}$ & $\mathrm{x}$ & $\mathrm{x}$ \\
Vernolate & $1929-77-7$ & .1 & & $\mathrm{x}$ & & \\
& Gross polychlorinated compounds & & & & \\
Polychlorinated biphenyls (PCB's) & $1610-18-0$ & $.1(.008)$ & $\mathrm{x}$ & $\mathrm{x}$ & $\mathrm{x}$ & $\mathrm{x}$ \\
Polychlorinated naphthalenes (PCN's) & $7287-19-6$ & .1 & $\mathrm{x}$ & $\mathrm{x}$ & $\mathrm{x}$ & $\mathrm{x}$ \\
\hline
\end{tabular}


Table 24. Site identifiers, site use, and years sampled

[Site use: 1 , irrigation; $S p$, spring; $P$, public supply; $H$, domestic; $Q A$, quality assurance; $S$, stock; $D$, dairy; $C$, commerical; $O$, observation]

\begin{tabular}{|c|c|c|c|c|c|c|c|c|}
\hline $\begin{array}{c}\text { Site } \\
\text { identifier }\end{array}$ & Site use & 1989 & 1990 & 1991 & 1992 & 1993 & 1994 & 1995 \\
\hline $\mathrm{MV}-1$ & I & $x$ & $x$ & & & $x$ & & \\
\hline MV-2 & $\mathrm{H}$ & $x$ & & $x$ & & & $\mathrm{x}$ & \\
\hline MV-3 & I & $x$ & & & $x$ & & & $x$ \\
\hline MV-4 & I & $x$ & $x$ & & & $x$ & & \\
\hline$M V-5$ & I & $\mathrm{x}$ & & & $x$ & & & $x$ \\
\hline MV-6 & I & $x$ & & & $x$ & & & $x$ \\
\hline MV-7 & I & $x$ & & & $x$ & & & $x$ \\
\hline MV-8 & QA & $x$ & $x$ & & & $x$ & & \\
\hline MV-9 & I & $x$ & $\mathrm{x}$ & & & $\mathrm{x}$ & & \\
\hline$M V-10$ & I & $x$ & & $\mathrm{x}$ & & & $\mathrm{x}$ & \\
\hline$M V-11$ & I & $x$ & $\mathrm{x}$ & & & $\mathrm{x}$ & & \\
\hline MV-12 & D & $x$ & & $\mathrm{x}$ & & $x$ & & \\
\hline$M V-13$ & I & $x$ & & & $x$ & & & $x$ \\
\hline$M V-14$ & $\mathrm{H}$ & $x$ & $x$ & & & $x$ & & \\
\hline MV-15 & $\mathrm{Sp}$ & $x$ & $x$ & & & $x$ & & \\
\hline MV-16 & $\mathrm{Sp}$ & $x$ & & $\mathrm{x}$ & & & $x$ & \\
\hline$M V-17$ & $\mathrm{Sp}$ & $x$ & & & $x$ & & & $x$ \\
\hline MV-18 & $\mathrm{Sp}$ & $x$ & $x$ & & & $\mathrm{x}$ & & \\
\hline MV-19 & $\mathrm{Sp}$ & $x$ & & $x$ & & & $\mathrm{x}$ & \\
\hline MV-20 & $\mathbf{I}$ & $x$ & & & $x$ & & $\mathrm{x}$ & \\
\hline MV-21 & $\mathrm{D}$ & $x$ & $\mathrm{x}$ & & & $\mathrm{x}$ & & \\
\hline MV-22 & $\mathrm{QA}$ & $\mathrm{x}$ & $x$ & & & $x$ & & \\
\hline$M V-23$ & I & $\mathrm{x}$ & $x$ & & & $\mathrm{x}$ & & \\
\hline $\mathrm{MV}-24$ & $\mathrm{H}$ & $\mathrm{x}$ & & $x$ & & & $x$ & \\
\hline MV-25 & $\mathbf{H}$ & $\mathrm{x}$ & $\mathrm{x}$ & & & & $x$ & \\
\hline$M V-26$ & I & $x$ & & $x$ & & & & $\mathrm{x}$ \\
\hline$M V-27$ & I & $x$ & & & $x$ & & & $x$ \\
\hline$M V-28$ & $\mathrm{QA}$ & $x$ & & $x$ & & & $x$ & \\
\hline$M V-29$ & I & $x$ & & $x$ & & & $\mathrm{x}$ & \\
\hline MV-30 & $C$ & $x$ & $x$ & & & $x$ & & \\
\hline MV-31 & I & $x$ & & & $\mathrm{x}$ & & & $x$ \\
\hline MV-32 & $\mathrm{H}$ & $x$ & & $\mathrm{x}$ & & & $x$ & \\
\hline MV-33 & $\mathrm{H}$ & $x$ & $x$ & & & $\mathrm{x}$ & & \\
\hline MV-34 & $\mathrm{QA}$ & $x$ & & $x$ & & & $x$ & \\
\hline MV -35 & I & $x$ & & & $x$ & & & \\
\hline MV-36 & $P$ & $x$ & & & $x$ & & & $x$ \\
\hline MV-37 & $\mathrm{H}$ & $\mathrm{x}$ & $\mathrm{x}$ & & & $x$ & & \\
\hline MV-38 & $\mathrm{I}$ & $x$ & & & $x$ & & & $x$ \\
\hline
\end{tabular}


Table 24. Site identifiers, site use, and years sampled-Continued

\begin{tabular}{|c|c|c|c|c|c|c|c|c|}
\hline $\begin{array}{c}\text { Site } \\
\text { identifier }\end{array}$ & Site use & 1989 & 1990 & 1991 & 1992 & 1993 & 1994 & 1995 \\
\hline MV-39 & $I$ & $x$ & $x$ & & & $\mathrm{x}$ & & \\
\hline MV-40 & 1 & $x$ & & $x$ & . & & $x$ & \\
\hline$M V-41$ & $I$ & $x$ & & $x$ & & & $x$ & \\
\hline$M V-42$ & $\mathrm{H}$ & $x$ & & $x$ & & & & $x$ \\
\hline$M V-43$ & I & $x$ & $x$ & & & $x$ & & \\
\hline$M V-44$ & QA & $x$ & & & $x$ & & & $x$ \\
\hline$M V-45$ & $I$ & $x$ & & $x$ & & & & $x$ \\
\hline$M V-46$ & I & $x$ & & & $x$ & & $x$ & \\
\hline $\mathrm{MV}-47$ & $\mathrm{D}$ & $x$ & $x$ & & & $x$ & & \\
\hline$M V-48$ & 0 & $x$ & & $x$ & & & $x$ & \\
\hline$M V-49$ & $S$ & $x$ & & $x$ & & & $x$ & \\
\hline MV-50 & I & $x$ & & & $x$ & & $x$ & \\
\hline$M V-51$ & $\mathrm{H}$ & $\mathrm{x}$ & $x$ & & & $x$ & & \\
\hline$M V-52$ & $\mathrm{H}$ & $\mathrm{x}$ & & $x$ & & & $x$ & \\
\hline$M V-53$ & $\mathrm{H}$ & $\mathrm{x}$ & & & $x$ & & & $x$ \\
\hline$M V-54$ & $\mathrm{H}$ & $x$ & & $x$ & & & $x$ & \\
\hline$M V-55$ & I & $x$ & & & $x$ & & & $x$ \\
\hline$M V-56$ & $\mathrm{H}$ & $x$ & & $x$ & & & $x$ & \\
\hline MV-57 & $S$ & $x$ & & & $\mathrm{x}$ & & & $x$ \\
\hline MV-58 & $S$ & $x$ & & & $\mathrm{x}$ & & & $x$ \\
\hline MV-59 & $S$ & $x$ & $x$ & & & $x$ & & \\
\hline$M V-60$ & $\mathrm{QA}$ & $x$ & & & $x$ & & & $x$ \\
\hline$M V-61$ & 0 & $x$ & $x$ & $x$ & & $x$ & & \\
\hline $\mathrm{MV}-62$ & $\mathrm{QA}$ & & & $x$ & & & & \\
\hline$M V-62(A)$ & QA & & & & $x$ & & & \\
\hline$M V-62(B)$ & $\mathrm{QA}$ & & & & $\mathrm{x}$ & & & \\
\hline$M V-62(C)$ & QA & & & & $x$ & & & \\
\hline
\end{tabular}

